\title{
Geology and Mineral Deposits of the Upper Chulitna District, Alaska
}

GEOLOGICAL SURVEY PROFESIONAL PAPER 758-B

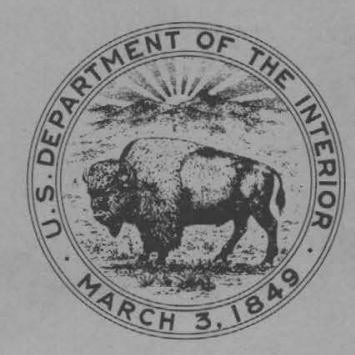





\section{Geology and Mineral Deposits of the Upper Chulitna District, Alaska}

By C. C. HAWLEY and ALLEN L. CLARK

GEOLOGY AND MINERAL DEPOSITS OF THE UPPER CHULITNA AND YENTNA DISTRICTS, SOUTH ${ }_{\digamma}$ CENTRAL ALASKA

GEOLOGICAL SURVEY PROFESSIONAL PAPER 758 -B

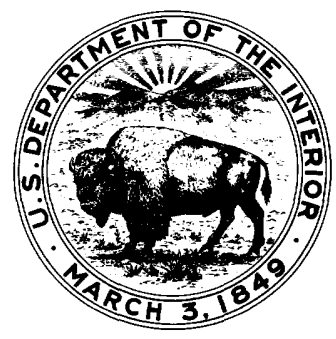

UNITED STATES GOVERNMENT PRINTING OFFICE, WASHINGTON $: 1974$ 


\section{UNITED STATES DEPARTMENT OF THE INTERIOR}

ROGERS C. B. MORTON, Secretary

\section{GEOLOGICAL SURVEY}

V. E. McKelvey, Director

Library of Congress Catalog-card No. 73-600360:

For sale by the Superintendent of Documents, U.S. Government Printing Office Washington, D.C. 20402 - Price $\quad \$ 2.75 \quad$ (paper cover)

Stock Number 2401-02546 


\section{CONTENTS}

Abstract

Introduction

Location and geography

Previous work

Work of this investigation and acknowledgments

General geology

Stratified rocks ....................................................................

Pre-Permian rocks

Permian(?) to Paleocene(?) rocks.

Permian(?) rocks

Basalt, siliceous argillite, and bedded chert

Permian (?) and Triassic rocks

Red beds and associated strata.

Triassic rocks

Limestone, calcareous siltstone, and argillite

Triassic(?) rocks

Jurassic (?), Cretaceous, and

$$
\text { Tertiary (?) rocks }
$$

Argillite, graywacke, and conglomerate..

Tertiary rocks

Quaternary deposits

Intrusive igneous rocks

Serpentinite

Gabbro and basalt

Diorite porphyry

Quartz diorite and quartz diorite

Granite and granite porphyry

Structure

Folds

Faults

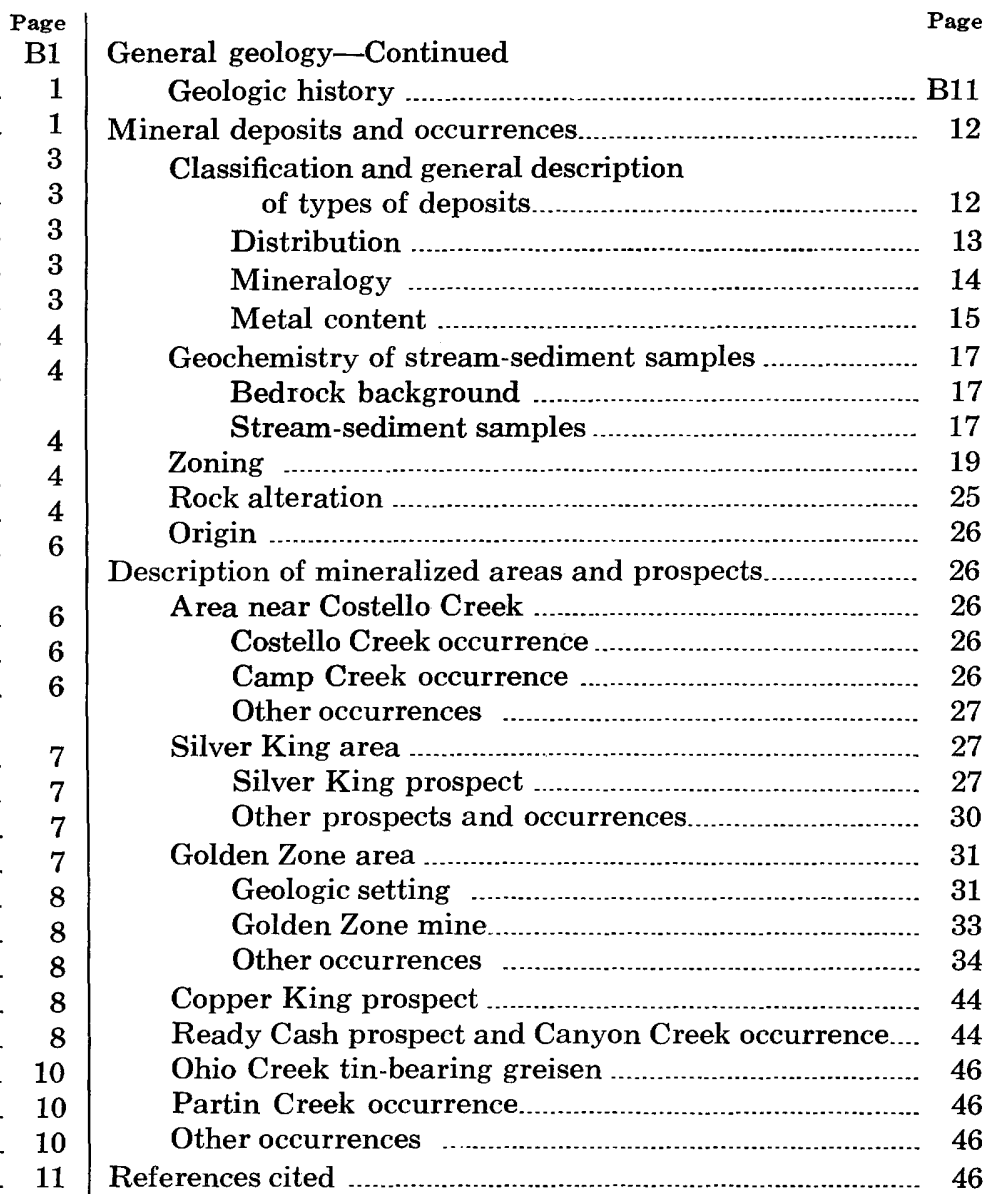

\section{ILLUSTRATIONS}

1. Reconnaissance geologic map and section of the Upper Chulitna district, Alaska

2. Geologic maps and section near the Golden Zone mine, Upper Chulitna district, Alaska

1. Index map of the Upper Chulitna district

FIGURE

2. Frequency distribution diagrams for gold, copper, lead, chromium, and nickel in bedrock...

B2

3. Map showing elements present in anomalous concentration in stream-sediment samples.

4. Frequency-distribution diagrams for gold, chromium, copper, nickel, and lead in stream-sediment samples..

5. Frequency-distribution diagrams for silver, zinc, and arsenic in stream sediments

6. Geologic maps of the Silver King area.

7. Map of mine workings at the Golden Zone mine showing assays.

8. Photographs of sulfides in breccia, Golden Zone deposit.

9. Sketch map of the Riverside prospect. 


\section{TABLES}

TABLE 1. Chemical composition of quartz diorite from the Upper Chulitna district compared with the average dacite and average high-calcium granitic rock.

2. Semiquantitative spectrographic analyses from the Ohio Creek tin-bearing stock.

3. Classification of epigenetic lode deposits of occurrences of the Upper Chulitna district, with examples

4. Analyses of veins, breccia, and massive sulfide deposits.

5. Analyses of rocks with disseminated sulfides.

6. Analyses of representative rock types of the Upper Chulitna district

7. Comparison of medians and percent of element detection in bedrock and stream-sediment samples

8. Chemical composition of altered and unaltered biotite quartz diorite porphyry from the Golden Zone stock and gains and losses in alteration.

9. Trace-element composition of altered and unaltered biotite quartz diorite porphyry from the Golden Zone stock

10-16. Analyses of rock samples:

10. Costello Creek and other occurrences in the northern part of the district.

11. Silver King prospect.

12. Other prospects and occurrences in the Silver King area

13. Dike rocks from the Golden Zone mine area.

14. Golden Zone mine area.

15. Rock and stream-sediment samples from the Golden Zone mine area

16. The Ready Cash prospect, Canyon Creek occurrence, Ohio Creek tin-bearing greisen, Partin Creek occurrence, and other occurrences in the southern part of the Upper Chulitna district 


\title{
GEOLOGY AND MINERAL DEPOSITS OF THE \\ UPPER CHULITNA AND YENTNA DISTRICTS, SOUTH-CENTRAL ALASKA
}

\section{GEOLOGY AND MINERAL DEPOSITS OF THE UPPER CHULITNA DISTRICT, ALASKA}

\author{
By C. C. Hawley and Allen L. Clark
}

\begin{abstract}
The Upper Chulitna district, on the southern flank of the west-central Alaska Range, is the northern part of the ChulitnaYentna Mineral belt. It is underlain mainly by sedimentary and volcanic rocks of pre-Permian to Paleocene (?) age. Weakly metamorphosed pre-Permian rocks crop out along the southeast flank of the district and are succeeded stratigraphically-with unconformity - by nonmetamorphosed red beds, volcanic, and volcaniclastic rocks of Permian(?) and Early Triassic age. Limestone, calcareous siltstone, and argillite of Middle(?) and Late Triassic age, pillow basalt, limestone and questionably assigned to the Late Triassic, and dark argillaceous and arenaceous rocks of Jurassic(?), Cretaceous, and Paleocene(?) age successively overlie the red-bed-rich sequence. Coal-bearing rocks of Oligocene age locally overlie the older strata, and glacial and fluviatile deposits cover large parts of the district.

The sedimentary and volcanic sequence of Paleocene(?) and older age is cut by small stocks and dikes of hypabyssal intermediate to silicic rocks and by elongate masses of ultramafic rock, gabbro, and basalt.
\end{abstract}

The intrusion of the igneous rocks followed folding and was contemporaneous with, or later than, major faulting of the Paleocene(?) and older rocks, but preceded deposition of the Oligocene unit and minor warping and faulting.

Rock units, fold axes, and faults have a common northeasterly strike, giving the district a pronounced structural grain, also seen in the distribution of epigenetic mineral deposits and of small syngenetic deposits in serpentinite.

The major epigenetic deposits are the combined vein-disseminated type, as at Canyon and Partin Creeks, and the breccia pipe deposit at the Golden Zone mine; the minor types are the veins, lode zones, and massive sulfide bodies.

Arsenopyrite characterizes the epigenetic deposits, and chalcopyrite; pyrrhotite and pyrite are locally abundant. In detail the mineralogy of the deposits is complex. Minerals such as cassiterite, stibnite, and bismuthinite are known at one or more deposits or occurrences; metallic components of these minerals, such as arsenic, copper, and gold, characterize the lode deposits of the district and are locally found in anomalous concentration in stream-sediment samples.

Relative abundance of copper, arsenic, and gold in different parts of the Golden Zone deposits suggests zoning on an ore body scale, and limited data from rock and stream-sediment samples of the district are consistent with zonal distribution of metals on a large scale.

Alteration near mineral occurrences and deposits includes argillization of siltstones, propylitization of basaltic rocks, and quartz carbonate alteration of porphyries. Comparison of quantitative analyses of altered and unaltered rocks at the Golden Zone suggest the introduction of hydrogen, carbon dioxide, arsenic, and sulfur during alteration.

\section{INTRODUCTION}

Occurrences of gold, copper, arsenic, and other metallic minerals are so alined along the southeast flank of the west-central Alaska Range as to define a belt that can be traced from Collinsville to near Bull River, the Chulitna-Yentna mineral belt (Hawley and Clark, 1973). The belt, parallel to the strike of sedimentary and volcanic rocks of dominant Mesozoic age and to prominent faults, is a $i$ least partly coextensive with areas containing ultramafic to granitic intrusive rocks of Tertiary(?) age. This report describes the generai geology and mineral deposits of the northern part of the Chulitna-Yentna mineral belt, here called the Upper Chulitna district.

Geologic studies made in 1967 and 1968 show that distinctive sedimentary rock units, particularly siliceous argillite and graywacke, red beds, a main limestone unit, and dark argillite, graywacke, and conglomerate, can be followed for most of the length of the district and form a very complex homoclinal pattern. Other results of the studies are the recognition of a serpentinite belt alined parallel to the long axis of the district, the occurrence of copper and other metals in limestone and basalt on the southwest flank of the district, and the presence of tin in greisen and in metalliferous veins.

\section{LOCATION AND GEOGRAPHY}

The Upper Chulitna district is on the southeast flank of the west-central Alaska Range, 10-20 miles west of The Alaska Railroad (fig. 1). The northern part of the district was formerly accessible by road from Colorado station, but parts of the road are badly overgrown and the three main bridges are out. The district is at present most accessible by helicopter, but bush planes land on 


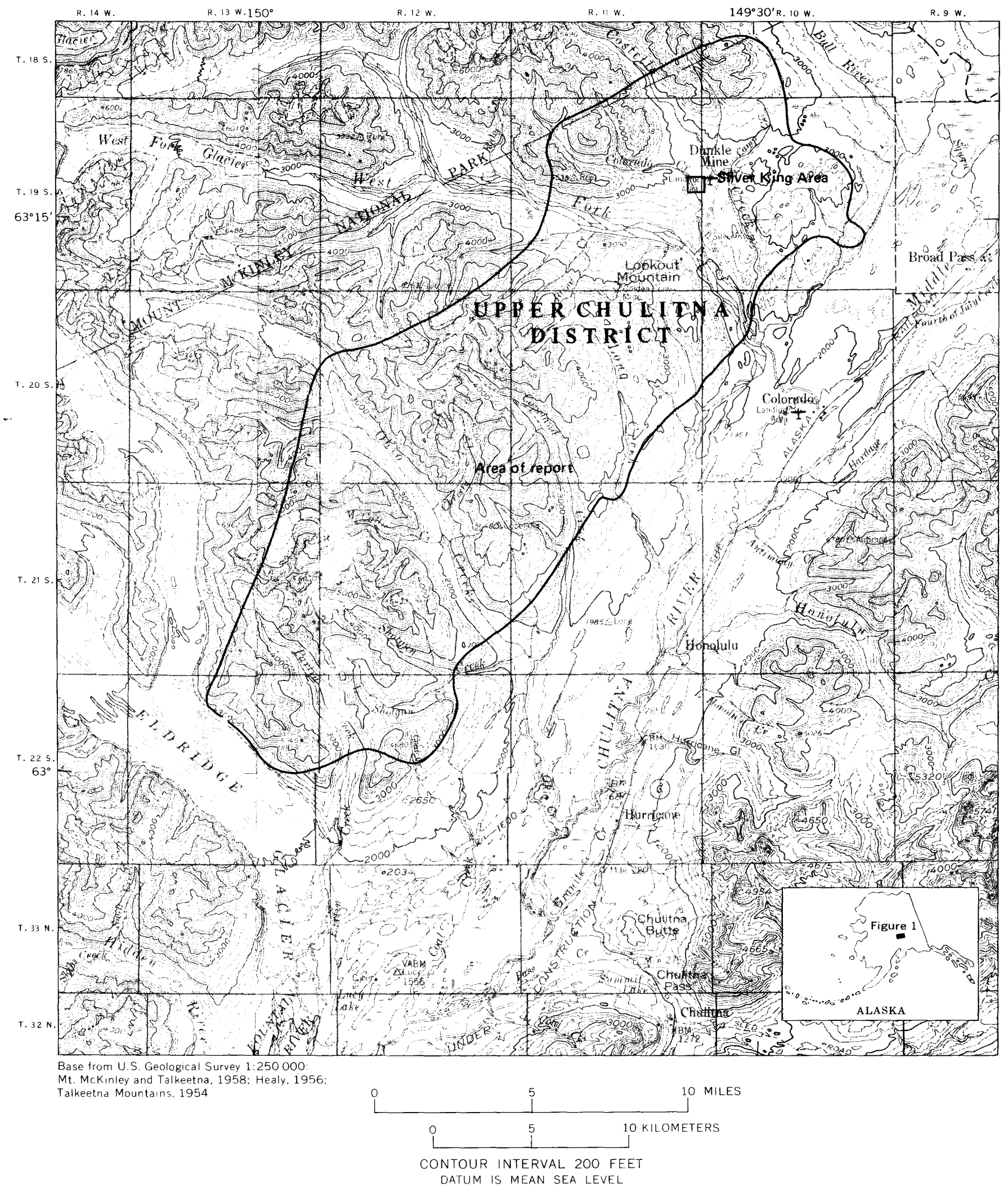

FIGURE 1.-The Upper Chulitna district. 
short airstrips along the West Fork of the Chulitna River, at the Dunkle coal mine north of the West Fork, and on ridges and gravel bars elsewhere. Wide valleys such as Partin, Shotgun, Ohio, Copeland, and the West Fork of the Chulitna River are suitable for construction of landing strips or roads; and most of the district could, with development, be easily accessible from The Alaska Railroad.

Relief in the district is more than 4,000 feet; the altitude ranges from less than 2,000 feet in the valleys of Ohio Creek and the West Fork of the Chulitna to more than 6,000 feet on peaks in the northwestern part of the district. The valley glaciers in the western part of the district are not now as extensive as shown on the Healy series 1:63,360 maps. Glaciers covered most of the area during parts of the Pleistocene, and glacial and other surficial deposits mask much of the bedrock below about 3,500 feet. Timberline is at approximately 3,500 feet, and brush is locally heavy; even in the country below timberline, most valley walls of the main and tributary streams have fair to good exposures. Climatic data applicable to the district have been summarized by Ross (1933a), Wahrhaftig (1958), and Mulligan, Warfield, and Wells (1967).

\section{PREVIOUS WORK}

Parts of the Upper Chulitna district have been described in two U.S. Geological Survey reports-one by Capps (1919) and one by Ross (1933a). Ross (1933a) mapped the district at a reconnaissance scale; he recognized the essential elements of structure, including the numerous faults, the abundant volcaniclastic rocks, and the potential of the mineral occurrences. We gratefully acknowledge his work and views.

Pertinent data on the general geology of the northern part of the district and adjacent and nearby areas to the north are found in reports by Moffit (1915), Wahrhaftig (1958), Wahrhaftig and Black (1958), and Moxham, Eckhart, and Cobb (1959). Wahrhaftig (1944) also mapped the Costello Creek coal field, and some of his mapping near the Dunkle coal mine has been incorporated in figure 2 . The only broad geologic picture of the region is given in Capps' report (1940) on the Alaska Railroad belt.

\section{WORK OF THIS INVESTIGATION AND ACKNOWLEDGMENTS}

The Upper Chulitna district was mapped during 1967 and 1968, largely on 1:48,000-scale topographic maps enlarged from the Healy A5, A6, B5, and B6 $1: 63,360$ quadrangle maps of the U.S. Geological Survey. The northern part of the district was mapped on a 1:12,000 enlargement of the Healy series maps, and certain areas were mapped by planetable at a scale of
$1: 2,400$. The detail of mapping generally corresponds to $1: 63,360$ on the $1: 48,000$-scale base and to $1: 24,000$ on the $1: 12,000$ base.

Geologic mapping was principally by the authors, assisted in 1967 by Jon Alan Benfer and in 1968 by M. A. Herdrick and Sandra H. B. Clark. L. A. Anderson, assisted by Gordon Johnson and E. D. Seals, was with the party in late July and early August 1968. In all, about 9 weeks were spent in the district; most of the 1:48,000-scale mapping was done with helicopter support in 3 weeks.

Data and ideas on the Upper Chulitna district were graciously provided by J. J. Mulligan, of the U.S. Bureau of Mines, and C. F. Herbert, a consultant geologist in Anchorage. C. L. Sainsbury, of the U.S. Geological Survey, examined Bureau of Mines drill cores from the Golden Zone in 1952 and believed the deposit and adjacent area to be worthy of detailed investigation. We are grateful to W. H. Greene, owner of the Mayflower claims, for the use of his cabin and for his informative letters on the district. Rea Beckwith and Cemco, Inc., present claimants of the Golden Zone group (called by them the BOB group), sent us maps and gave us advice on access to the area.

\section{GENERAL GEOLOGY}

The Upper Chulitna district is underlain mainly by stratified rocks of Paleozoic to Tertiary age that can be divided into three groups by two prominent angular unconformities. One unconformity separates prePermian from Permian rocks, the second, separates rocks of Permian to Paleocene(?) age from Oligocene coal-bearing strata. The Permian(?) to Paleocene(?) strata of the district were folded around northeasttrending axes and were faulted in a northeasterly direction before the emplacement of ultramafic to mafic igneous rocks that are older than the coal-bearing rocks.

\section{STRATIFIED ROCKS}

The stratified rocks of the district consist of sedimentary and volcanic or volcaniclastic rocks which are predominantly of marine deposition and subordinantly of continental deposition.

\section{PRE-PERMIAN ROCKS}

Weakly metamorphosed slaty argillite, banded siliceous argillite, and massive to schistose graywacke of pre-Permian age underlie the southeastern part of the district; these rocks form a strip that extends at least from Eldridge Glacier to Costello Creek and parallels the main valley of the Chulitna River (pl. 1). The northwest boundary of the pre-Permian Paleozoic rocks is subparallel to, and locally coincides with, the Upper 
Chulitna fault zone. The pre-Permian rocks of this report correspond to the Devonian(?) chloritic rocks of Ross (1933a, pl. 25, p. 294), Paleozoic sedimentary rocks of Capps (1940, pl. 2), and the chert, quartzite, and argillite unit of Tuck $(1934$, p. 113).

The pre-Permian rocks can be divided into two main lithologic units, a predominantly argillaceous unit and a siliceous argillite and metagraywacke unit that is apparently the older of the two. The argillaceous unit is well stratified to strongly cleaved, apparently because of its proximity to the major fault zones. Near the Upper Chulitna fault, as at Lookout Mountain, the argillic units are broken by curving cleavage surfaces that dip steeply but approximate the bedding. The more competent graywacke and impure quartzite unit, present as boudins, are less deformed than the strongly deformed argillite. Argillaceous rocks exposed unconformably below red beds about $1 \frac{1}{2}$ miles east of the Golden Zone mine are bedded on a scale of approximately 1 inch. The silty argillite beds, dark-gray to pale-greenish gray, weather pale red and green to form a strikingly banded rock. Other parts of the argillaceous unit near the Golden Zone have graywacke interlayers.

The siliceous argillite and metagraywacke unit is well exposed in the canyon of Long Creek and on the valley walls of Copeland and Ohio Creeks. On the uplands isolated outcrops of it form rounded hills. Along Long Creek the unit is green to black and weathers very pale gray. The siliceous argillite is layered with cyclic green to black bedding on 1- to 3-inch scale. Metagraywacke, impure quartzites, and sparse conglomerates predominate in the unit north of the West Fork of the Chulitna. Locally these rocks contain very fine grained disseminated biotite, which indicates low-grade regional metamorphism.

Ross (1933a, pl. 25, p. 294) correlated the prePermian strata with similar strata in the Broad Pass region (Moffitt, 1915, p. 24-27, p. 74); however, Edwin Kirk (in Moffitt, 1915, p. 25) assigned this strata to a late Middle or early Late Devonian age. Although the rocks of both regions are on strike, the intervening area is largely covered by glacial deposits, thus making direct correlation speculative.

\section{PERMIAN(?) TO PALEOCENE(?) ROCKS}

The weakly metamorphosed strata of pre-Permian age are either overlain with sharp angular unconformity by, or faulted against, a complex of unmetamorphosed sedimentary, volcanic, and volcaniclastic rocks. The Permian(?) to Paleocene(?) strata, though of a long time interval, are folded together and are bounded at top and bottom by major unconformities. In general order of decreasing age, the rocks are: (1) Basalt, siliceous argillite, and bedded chert of Permian(?) age;
(2) red beds and associated strata of Permian(?) and Early Triassic age; (3) limestone, calcareous siltstone, and argillite of Middle(?) and Late Triassic age; (4) limestone and pillow basalt of probable Late Triassic age; and (5) argillite, graywacke, and conglomerate of Jurassic(?), Cretaceous, and Paleocene(?) age.

\section{PERMIAN(?) ROCKS}

BASALT, SILICEOUS ARGILLITE, AND BEDDED CHERT

The rocks of the basalt, argillite, and chert unit crop out in a belt near the Upper Chulitna fault zone from about 1 mile south of Lookout Mountain to about 11/2 miles northeast of Ohio Creek (pl. 1).

The basaltic rocks are fine grained and greenish black, are crudely layered, and locally show pillow structure. Irregular masses of red chert or jasperoid and carbonate are found in the basalt. On the sharp ridge south of Copeland Creek to the divide between Copeland and Ohio Creek, bedded chert and siliceous argillite are about as abundant in the unit as basalt. The chert is dark reddish brown, is commonly iron or manganese stained, and is in $1 / 2^{-}$to 1 -inch regular layers. Argillite interbeds are generally sheared and iron stained.

\section{PERMIAN(?) AND TRIASSIC ROCKS}

RED BEDS AND ASSOCIATED STRATA

Red siltstone, sandstone, conglomerate with interlayered limestone, tuff, volcanic conglomerate, and sparse basalt can be traced from Eldridge glacier northward to near the Silver King prospect north of the West Fork of the Chulitna River. These rocks either overlie or grade into, the basalt, siliceous argillite, and bedded chert unit. The red-bed sequence, however, contains abundant red chert clasts like the chert of the basaltrich unit and may therefore be somewhat younger. Both units are in angular unconformity with the older Paleozoic rocks.

The thickness of the red-bed unit is hard to estimate because of tight folding and faulting. Measurements from a cross section at a place where the structure apparently is fairly simple (sec. $A-A$, pl. 1) suggests that the red-bed unit is approximately 1,000 feet thick.

The predominant constituents of the unit are red siltstone and conglomerate which are interlayered on the scale of a few inches to 10-20 feet. Minor units, which are predominant locally, are pale-green crystal tuff, massive tuff with sparse green siltstone interlayers, volcanic conglomerate and breccia, and limestone. The conglomerate and breccia units vary widely in lithology but are mainly quartz pebble and volcanic pebble conglomerates. Clasts range in size from pebbles to boulders as much as 3 feet in diameter with all 
gradations in angularity. The clasts consist mainly of white quartz, red chert, red siliceous argillite, black argillite, and intermediate and mafic igneous rocks. Near the West Fork of the Chulitna and in Long Creek, fragments of volcanic rocks and red chert are the most abundant clasts; near Copeland and Ohio Creeks, white quartz clasts are abundant.

The matrix of the quartz pebble conglomerate is red argillic material containing silt-sized quartz. The volcanic conglomerates have a tuffaceous matrix with abundant crystal fragments.

At most places the conglomerates are stratified and interlayered with siltstone; these sediments were transported by and deposited in water. At other places, the sediments, though probably water laid, have close volcanic affinities, especially those sediments that have a breccia fabric and tuffaceous matrix. Locally, conglomerates or breccias with angular clasts appear to have been deposited with much open space, either still preserved or filled with coarse calcite. Rocks that are similar in appearance to stratified conglomerate and breccia appear to be pipe- or vent-filling agglomerates. A possible example is the "conglomerate" exposed about 2,000 feet southwest of the Golden Zone stock. (See pl. 2.)

The common siltstone of the red beds, which is brick to maroon red, is composed of quartz fragments in a calcareous or dolomitic argillaceous matrix. X-ray diffraction patterns show quartz, chlorite, either calcite or dolomite, and hematite.

The red siltstone and conglomerate units are locally metamorphosed into hornfels and hydrothermally altered. Near the Golden Zone and Silver King deposits, the conglomerate (and breccia) is a nearly white, dense calcitic rock which contains disseminated pyrrhotite and arsenopyrite. Siltstone near the Golden Zone is pale green and commonly weathers to jarositic yellow brown. It is pyritic or strongly argillized.

Limestones occur in thin layers and lenses in the red beds and in massive lenses near the base of the unit. Other limestones occur above the red-bed sequence, but these are younger and are assigned to the upper limestone-calcareous argillite unit.

Fossiliferous limestone of late Paleozoic age has been found at four localities within the red-bed unit, from north to south: 1 , in the canyon of Colorado Creek near the Silver King prospect; 2, on a roadcut between the West Fork and the Golden Zone mine; 3, south of Long Creek, and 4, on the ridge between Ohio and Shotgun Creeks (pl. 1):

Fossil locality 1, pl. 1; field No. 68AHx 272 (USGS 23753-PC). A bryozoan Rhombotrypella sp? and echinoderm debris, including pelmatozoan columnals as much as 1 inch in diameter.
Fossil locality 2, pl. 1, field No. 67ACx74. Detrital limestone with brachiopods, bryozoans, and crinoid columnals.

\section{Brachiopods \\ Avonia (?) \\ Martiniopsis (?) \\ Bryozoan \\ Rhombotrypella}

Fossil locality 3, pl. 1, field No. 68ACK218 (USGS 23402-PC). According to J. T. Dutro, Jr. (written commun., 1969) :

This collection is definitely Paleozoic in age, most probably Permian. In addition to echinoderm debris (including large crinoid columnals) the collection contains productoid brachiopods, Waagenoconch and probable Linoproductus, and a large terebratuloid Dieslasma cf. D. giganteum Tschernyschew. A member of massive and ramose bryozoans and a single indeterminate horn coral are also present.

Fossil locality 4, pl. 1, field No. 68ACs823F (USGS 23693-PC). The fossils in the collection, examined by John Pojeta, Jr., E. L. Yochelson, and R. E. Grant, were pelecypods, mollusks, and brachiopods. Only the pelecypods were diagnostic, and according to Pojeta (written commun., 1969) :

The dominant pelecypod in this collection is a species of Streblopteria ranges throughout the upper Paleozoic but has not been reported from post-Paleozoic rocks.

Other pelecypods in the collection are not well preserved; identifications of these are as follows:

?Pseudomonotis sp.

Phestia sp.

pelecypods, genus $\&$ sp. indet.

Of the identifiable pelecypods in the collection Streblopteria and ?Pseudomonotis are epifaunal whereas Phestia is infaunal.

Another collection was made from a 6 -inch limestone interbed in red beds:

Fossil locality 5, pl. 1, field No. 68AHx331 (USGSM5027). One fossil collection from limestone apparently in the red-bed unit indicates an Early Triassic age (locality 6, pl. 1, USGS collection No. M5027). The limestone exposed in a roadcut below the Golden Zone mine contains an abundant ammonoid fauna which $\mathrm{N}$. J. Silberling believed significant. He reports (written commun., 1967) :

This fauna has close affinity with that of the Meekoceras gracilitatus Zone in the conterminous western United States as well as with that of the Euflemingites romunderi Zone of northeastern British Columbia and arctic Canada and Alaska. In the biostratigraphic classification of the North American marine Triassic by Silberling and Tozier (1968), these two zones are regarded as geographically distinct correlatives, both of which represent the lower Scythian Stage or about the middle of the Lower Triassic ***.

This occurrence of Scythian rocks in the Alaska Range has considerable paleogeographic significance, for correlative strata are known in Alaska only in the Brooks Range and North Slope and are evidently not present in the upper Yukon area, Wrangell Mountains, Alaskan Peninsula, or Southeastern Alaska where strata of late Middle Triassic or Late Triassic 
age rest directly on the Permian. Although only Dieneroceras, Prosphingites, and Arctoceras are well represented in this fauna, and comparisons are therefore uncertain, the ammonites present are in general more like those found in the Scythian at lower present latitudes in the conterminous United States than like those of the Scythian in Canada and northern Alaska.

Ammonoids:

Dieneroceras cf. D. knechti (Hyatt and Smith)

Euflemingites sp. indet. Immature specimen

Prosphingites cf. $P$. slossi Kummel and Steele

?Juvenites sp. indet. Immature specimen

Lanceolites bicarinatus Smith

Aspenites cf $A$. acutus Hyatt and Smith

Arctoceras cf. A. bloomstrandi (Lindström)

Wyomingites sp. indet.

Nautiloids:

Indet. orthocone

Pelecypods:

"Posidonia" mimer Oeberg

Unident. aviculopectinid

Unident. pteriid

These fossil collections suggest that the red-bed unit ranges in age from late Paleozoic, probably Permian, to Early Triassic. The Early Triassic limestone is apparently interlayered with the red beds but its contacts are not exposed; it is possible that it should be grouped with the overlying limestone-argillite unit. As pointed out by Silberling (written commun., 1967), however, the Early Triassic age is unique in this part of Alaska, and the authors believe that the limestone is more closely related to the red-bed series.

The interlayered red conglomerate and siltstone corresponds to Ross' (1933a) unit A, which he assigned to the Permian(?). He based his Permian(?) age assignment for the unit on fossils collected from a limestone southwest of Long Creek (Ross, 1933a, p. 2982) ; possibly from the same locality as our locality No. 3 .

TRIASSIC ROCKS

LIMESTONE, CALCAREOUS SILTSTONE, AND ARGILLITE

Comfortably overlying the red-bed unit is a unit at least 500 feet thick which is composed principally of limestone and calcareous siltstone and subordinately of calcareous argillite with graywacke interbeds. The limestone-siltstone-rich unit can be traced from Eldridge Glacier to near the West Fork of Chulitna River; it is generally west of the red beds and east of the overlying limestone-basalt-rich sequence but locally is infolded into both the overlying and underlying units.

The lower part of the unit is principally limestone of two distinct types-a pale-olive-green type that is abundantly fossiliferous and an almost white massive type that is sparsely fossiliferous. The nearly white limestone serves as a good marker bed. The prominent white limestones of the unit have been mapped (pl. 1) mostly by sketching from an opposite canyon wall. The stratigraphically younger part of the unit is sandier and siltier than the lower part.

The pale-olive-green limestone weathers to brown angular blocks several inches to 1 foot wide. It is sandy, locally has mud cracks, contains small clasts of the mudstone, and in many places is crossbedded. The sandy limestone that forms the base of the unit is well exposed on the ridge south of Copeland Creek.

The white limestone contains less arenaceous material than the olive-green type but is more massive and more crystalline.

Rocks of the upper predominantly silty and sandy part of the unit are generally slightly calcareous and consist of siltstone and graywacke, silty limestone, and calcareous argillite. In an overturned section a few hundred feet west of the Golden Zone mine, beds of graywacke, as much as 2 feet thick are present in argillite. The graywacke has graded bedding and, locally, scour structures. The silty limestone of the section is mud cracked. Thin section and X-ray studies show that the graywacke is mainly quartz, plagioclase, and chlorite; the argillite contains the same minerals and illitic clay.

The olive-green limestone is abundantly fossiliferous and contains fragments of pelecypods, gastropods, belemnites, and ammonoids. R. W. Imlay reported (written commun., 1969) that the fossils from localities 7 and 8 of plate 1 contained ammonite fragments suggestive of Triassic age. Other fossils were either too fragmentary or not diagnostic. The white limestone is less fossiliferous but contains a few corals. Ross (1933a, p. 298-300) dated a white limestone unit in upper Long Creek, based on sparse fossil data, as Late Triassic in age.

Throughout the unit, but primarily in the basal position, are discontinuous red beds similar in composition to those of the underlying red-bed unit. These small beds may represent local red-bed deposition with the younger rocks, or they may be structural slices emplaced by folding and (or) faulting.

\section{TRIASSIC(?) ROCKS}

\section{LIMESTONE AND PILLOW BASALT}

A strikingly banded unit that is composed of interlayered limestone and pillow lavas in layers of tens of feet thick overlies the limestone-siltstone-argillite from near Copeland Creek south and apparently thickens southward. A tongue of the unit, which may be the exposure of the crestal region of an asymmetric fold, lies farther to the west and extends almost to the West Fork of the Chulitna.

The limestone is nearly white and generally recrystallized; it is sparsely fossiliferous. The basalt layers are 
massive and locally highly vesicular or amygdaloidal. Unaltered basalt pillows occur locally in a serpentinized basalt matrix. Locally the contact between the limestone and basalt layers is marked by massive crystalline calcite in the limestone and serpentinized rock in the basalt and forms a contact zone 1-2 feet thick.

\section{JURASSIC (?), CRETACEOUS, AND TERTIARY (?) ROCKS}

ARgILLITE, GRAYWACKE, AND CONGLOMERATE

Stratigraphically above the limestone-pillow basalt unit is a sequence of dark fine- to coarse-grained detrital rocks thousands of feet thick. These rocks were mapped by foot traverse in the upper Costello and Colorado Creek drainages, and no attempt was made to separate the lithologic types. Judged by examination from scattered helicopter landings and the few traverses made, the lowermost rocks of the sequence are dark fine-grained argillite or cyclically interlayered graywacke and argillite. Boulders seen as float in upper Ohio Creek are dark-matrix quartz-argillite conglomerates, lithologically similar to much of the Cantwell Formation. The rocks in the sequence may become coarser grained higher in the section. In most places the rocks are deformed into northeast-trending folds, and locally they have a slaty cleavage.

Fossils were collected from the dark sequence at a locality in the upper Colorado Creek area, fossil locality 9 , and at another locality south of the West Fork of the Chulitna, locality 10. At locality 9, the fossils are pelecypods, Buchia sublaevis (Imlay), of Early Cretaceous (Valanginian age) age (D. L. Jones, written commun., 1968). The fossils at locality 10 occur in abundant platelike masses or layers, approximately $1 / 8$-inch thick, and are as yet unidentified.

The rocks of the dark sequence are believed to correlate generally with the argillite-graywacke of the Yentna district to the south that are regarded as of Jurassic and Cretaceous in age. Possibly some of the rocks are as young as the rocks of the Cantwell Formation, now regarded as Paleocene in age (Wolfe and Wahrhaftig, 1970).

\section{TERTIARY ROCKS}

The youngest sedimentary rocks of the district are coal-bearing arenaceous rocks of the Costello Creek coal field. These rocks crop out in the extreme northeastern part of the district and are either unconformable or in fault contact with the well-consolidated rocks of Permian(?) to Paleocene(?) age. The coaly rocks appear to have formed in local swamps and are preserved in downwarped and downfaulted basins (Wahrhaftig, 1944).

Although not studied extensively, the coal-bearing rocks and sandstones were sampled for their tracemetal content because plants are known to be metal accumulators and because the Healy coal not far to the north is locally auriferous (P. D. Rao, oral commun., 1967, and J. D. Vine, written commun., 1968). Gold and silver, along with zinc, tin, and other elements were found in the coals of the Costello Creek area but not in anomalous amounts. Anomalous amounts of both gold and copper were found in one sample of the basal conglomeratic sandstone of the unit in Colorado Creek.

The major coal seams in the Dunkle coal mine area are overlain by a thick sequence of silty sandstone and sandy siltstone. The clastic unit is more than 50 feet thick, but the total thickness is not known. The rocks are buff to dark brown and locally highly carbonaceous; they are well indurated and slightly calcareous and tend to break into platy fragments.

Concretions, a few inches to 2 feet in diameter, are locally abundant in the siltstone-sandstone unit. Many are septarian with well-developed calcite veination. The concretions which break parallel to the bedding plane have bedding surfaces with leaf impressions. The impressions are generally coated with a thin film of clay and, rarely, carbonaceous material.

Fossil leaves from the unit above the coal (fossil locality $11, \mathrm{pl} .1$ ) that were studied by Jack A. Wolfe indicate an Oligocene age. If this age is correct, the rocks are correlative with the Tsadaka Formation and the lower part of the Kenai Formation. According to Wolfe (written commun., 1967) fossil locality 11 (U.S. Geol. Survey Paleobot. locality 11120, field No. 67ACx 190) contains:

\section{Metasequoia glyptostroboides $\mathrm{Hu}$ and Cheng \\ Populus n. sp. \\ Alnus evidens (Holl.) Wolfe \\ Corylus harrimani Knowl. \\ Cercidiphyllus crenatum (Ung.) R. W. Brown}

The Cercidiphyllum indicates an age no older than middle Oligocene. The other dicotyledons have been found in floras of middle or late Oligocene age, and particularly the Alnus and Corylus are diagnostic of the middle and late Oligocene in Alaska.

Glacial drift and colluvium of Quaternary age, only locally mapped, cover much of the bedrock surface, especially below about 3,000 feet. These deposits were formed by one or more large piedmont glaciers that coalesced into a glacier filling the ancient valley of the Chulitna.

Major stream valleys, particularly those of the West Fork of the Chulitna and Ohio Creek, are filled with outwash and covered by alluvium of Paleocene and Holocene age.

The Quaternary geology of the area just north of the Upper Chulitna district has been described in detail by Wahrhaftig (1958). 


\section{INTRUSIVE IGNEOUS ROCKS}

The intrusive rocks of the district range from ultramafic to silicic and include serpentinite, grabbo, diorite, quartz diorite, and granite. Most of them form outcrops less than a square mile in area. With few exceptions the rocks of ultramafic and mafic composition were emplaced in elongate bodies in and near major fault structures. The rocks of intermediate and silicic or granitic composition form small plugs and stocks without a dominant direction of elongation and dikes mostly of northeast strike.

Geologic relations suggest that the intrusive igneous rocks are probably of early Tertiary age as proposed by Ross (1933a, p. 305). They cut rocks at least as young as Cretaceous and possibly Paleocene. They were emplaced after the host rocks were folded and faulted but before the deposition of coal-bearing rocks of Oligocene age.

\section{SERPENTINITE}

Serpentinite forms lenticular masses in a belt in and near the Upper Chulitna fault zone. The largest masses are in the part of the district between Eldridge Glacier to Long Creek; smaller bodies are found in Colorado and Costello Creeks north of the West Fork of the Chulitna.

The serpentinite is black to greenish black and is massive to strongly sheared. Locally it alters to a greenish-tan or brown quartz-carbonate rock. Thin sections and X-ray diffraction show that most serpentinite is composed essentially of clinochrysotile and lizardite. Locally, as in the body exposed north of Long Creek, the serpentine contains olivine and has a patchy or bastite texture suggestive of an original pyroxeneolivine ultramafic rock. Thin-sections show minor amounts of talc and possibly brucite. These minerals and the abundant quartz-carbonate rock indicate the hydrothermal metasomatic origins of the serpentinite. Massive chromite was found at one locality in serpentinite on the ridge between Copeland and Ohio Creeks (pl. 1); the chromite, in talus blocks as much as 1 foot across, assayed 39.5 percent $\mathrm{Cr}_{2} \mathrm{O}_{3}$. Most serpentinite of the belt contains about 1,000-2,000 ppm chromium and nickel; locally it contains $5,000 \mathrm{ppm}$ nickel and more than 5,000 ppm chromium (pl. 1).

\section{GABBRO AND BASALT}

Fine- to medium-grained rocks of basaltic composition form lenticular bodies intercalated with serpentinite and occur as lenses and plugs or stocks on the flanks of the main belt of serpentinite. The largest bodies are in the part of the district from near Shotgun Creek to the ridge north of Ohio Creek. Three lenticular masses are found in upper Long Creek and one mass in upper Costello Creek.
The rock identified as gabbro and basalt is a black to greenish black massive rock. In hand specimen, plagioclase, dark-greenish-black mafic minerals, and gray metallics, largely ilmenite, can be distinguished. Thin sections show that the rock is mainly plagioclase and pyroxene, both commonly altered, with interstitial serpentine minerals that possibly indicate the former resence of olivine. The plagioclase is euhedral in laths 1-5 mm long and $1 \mathrm{~mm}$ or less wide. Mafic or opaque metallic minerals fill the interstices between the plagioclase laths.

Locally the mafic rocks form intrusive breccias. The breccias have abundant carbonate both in their interstices and in the spherical masses that are 2-3 inches in diameter. They are found with massive gabbro and basalt and as in the Golden Zone area, in isolated bodies (pls. 1 and 2).

\section{DIORITE PORPHYRY}

Porphyritic rocks with aphanitic groundmasses are sparse to abundant phenocrysts of plagioclase, hornblende, and garnet crop out in the northeastern part of the district. Their largest exposure, a stock of several square miles, is east of Costello Creek. Three other small stocks or plugs of porphyry are found north of the West Fork, one body in the Golden Zone mine area (pl. 2).

These rocks, classed as diorite porphyry, range from greenish black to very dark reddish brown. Quartz is not visible megascopically and rarely present in thin section. The phenocrysts are commonly plagioclase and hornblende, which are about $5 \mathrm{~mm}$ long. Equant dark red garnets, $2-3 \mathrm{~mm}$ across, occur locally.

The porphyry in the stock of the Costello Creek copper occurrence is a dark-brownish-red hornblende diorite containing about 30 percent phenocrysts of euhedral hornblende and plagioclase $2-3 \mathrm{~mm}$ long set in a very fine grained mosaic of plagioclase crystals. The hornblende is green, slightly pleochroic, and generally altered. Apatite is the main accssory mineral; some magnetite is found in the altered hornblende.

\section{QUARTZ DIORITE AND QUARTZ DIORITE PORPHYRY}

Quartz diorite is found at scattered localities in the southern part of the district; it is more abundant and in larger plutons in the part of the district north of Long Creek. Quartz diorite porphyry is the host rock of the Golden Zone breccia pipe, and several other bodies of quartz diorite are mineralized locally.

The quartz diorites vary widely in texture and appearance. Most rocks range in color from pale greenish white to medium gray or green and they range in texture and composition from porphyries with an aphanitic matrix to medium-grained subequigran- 
ular rocks. Major or varietal minerals visible in hand specimen are hornblende or biotite, feldspar, and, rarely, quartz.

The quartz diorite porphyry of the Golden Zone stock is a gray rock with an aphanitic and almost glassy-appearing matrix containing abundant phenocrysts of feldspar and biotite, less abundant hornblende, and sparse quartz. The biotite flakes are as much as $2 \mathrm{~mm}$ in diameter and are a dark-reddishbrown. Local hornblende and plagioclase phenocrysts are as much as $5 \mathrm{~mm}$ long; quartz phenocrysts are as much as $2 \mathrm{~mm}$ long. Examination of thin sections shows that the phenocrysts make up about $40-70$ percent of the rock. This section shows that the hornblende and plagioclase are subhedral to euhedral, the biotite subhedral, and the quartz phenocrysts rounded. The matrix, as shown by the petrographic studies and mineral staining, is mainly $\mathrm{K}$-feldspar and quartz in grains less than $1 / 2 \mathrm{~mm}$ long arranged in mosaic fashion. Apatite is the main accessory mineral. All phenocryst minerals except biotite are embayed by the matrix. The plagioclase is normally zoned from about $\mathrm{An}_{35}$ to $\mathrm{An}_{25}$, and the approximate average anorthite contents of a single plagioclase sample measured by X-ray methods was $\mathrm{An}_{27}$. The hornblende is very pale green and only slightly pleochroic. Biotite is pleochroic ranging from very pale reddish brown to dark reddish brown.

Megascopic fresh material from the stock is seen in thin section to be slightly altered. The more calcic parts of the plagioclase crystals are sericitized; hornblende is altered in part to biotite, white mica, and carbonate. The rock is cut by thin calcite stringers.

The quartz diorite of the stock (analysis 1, table 1), though similar chemically to the average dacite of Nockolds (1954) (analysis 2A, table 1), differs by being more potassic and less calcic and ferruginous. The $\mathrm{K}_{2} \mathrm{O}$ is partly in sericite and biotite but principally in the groundmass of the $\mathrm{K}$-feldspar. The incipient alteration that is seen in thin section is shown by the high content of $\mathrm{CO}_{2}$ measured chemically.

The quartz diorite porphyry from an irregular dike complex about 2,000 feet west of the Golden Zone (pl. 2 ) has also been analyzed chemically (analysis 3 , table 1). This rock is similar to the Golden Zone porphyry in that it is less calcic and more potassic than typical dacite. However, it differs from the Golden Zone porphyry in that it is less silicic. Comparing the trace elements from both analyzed porphyries with the trace elements from the average high-calcium granitic rock of Turekian and Wedepohl (1961) (analysis 2B, table 1) suggests that the Golden Zone porphyry has an anomalously high content of barium and copper.

Inspection of hand specimens and thin sections shows that the porphyry from the Golden Zone stock contains more biotite and quartz and less hornblende than most quartz diorite porhyries of the district. Dike rocks, in particular, contrast with the Golden Zone porphyry by having a subtrachytic rather than a mosaic groundmass.

The quartz diorite that is exposed in the central part of a small stock 1 mile west of the Silver King prospect in sec. 24 , T. 19 S., R. $11 \mathrm{~W}$. is subequigranular with a hyalophitic texture. It is mainly composed of hornblende and plagioclase with subordinate biotite, quartz,

TABLE 1.-Chemical composition of quartz diorite from the Upper Chulitna district compared with the average dacite and average high calcium granitic rock

[Analysts: E. Engleman, bulk composition; R. H. Heidel, trace elements. Trace elements looked for but not found: $\mathrm{Ag}, \mathrm{Au}, \mathrm{Bi}, \mathrm{Cd}, \mathrm{Ce}, \mathrm{Ge}, \mathrm{Hf}, \mathrm{Hg}$ and Eu]

\begin{tabular}{|c|c|c|c|}
\hline & \multicolumn{3}{|c|}{ Bulk composition (weight percent) } \\
\hline & 1 & 2A & $\mathbf{3}$ \\
\hline $\begin{array}{l}\mathrm{SiO}_{2} \\
\mathrm{Al}_{2} \mathrm{O}_{3} \\
\mathrm{Fe}_{2} \mathrm{O}_{3} \\
\mathrm{FeO}\end{array}$ & $\begin{array}{r}63.65 \\
15.03 \\
.31 \\
3.55 \\
2.55\end{array}$ & $\begin{array}{r}63.58 \\
16.67 \\
2.24 \\
3.00 \\
2.12\end{array}$ & $\begin{array}{r}59.86 \\
15.41 \\
.35 \\
4.50 \\
3.07\end{array}$ \\
\hline $\begin{array}{l}\mathbf{C a O} \\
\mathbf{N a}_{2} \mathbf{O} \\
\mathbf{K}_{2} \mathbf{O} \\
\mathbf{H}_{2} \mathbf{O}^{(+1} \\
\mathbf{H}_{2} \mathbf{O}^{(-1}\end{array}$ & $\begin{array}{r}4.03 \\
3.13 \\
3.72 \\
1.14 \\
.12\end{array}$ & $\begin{array}{l}5.53 \\
3.98 \\
1.40 \\
.56 \\
-\end{array}$ & $\begin{array}{r}4.27 \\
3.14 \\
3.03 \\
2.31 \\
.22\end{array}$ \\
\hline $\begin{array}{l}\mathrm{TiO}_{2} \\
\mathrm{P}_{2} \mathrm{O}_{5} \\
\mathrm{MnO} \\
\mathrm{CO}_{2}\end{array}$ & $\begin{array}{r}.63 \\
.21 \\
.06 \\
1.50 \\
.04\end{array}$ & $\begin{array}{l}.64 \\
.17 \\
= \\
-\end{array}$ & $\begin{array}{r}.62 \\
.25 \\
.12 \\
2.36 \\
.00\end{array}$ \\
\hline \multirow{4}{*}{$\begin{array}{r}\mathbf{F} \\
\mathbf{S}^{1} \\
\begin{array}{r}\text { Subtotal } \\
\text { Less O } \\
\text { Total }\end{array} \\
\end{array}$} & $\begin{array}{l}.10 \\
.12 \\
\end{array}$ & 二 & $\begin{array}{l}.06 \\
.21 \\
\end{array}$ \\
\hline & $\begin{array}{r}99.89 \\
.11 \\
\end{array}$ & & $\begin{array}{r}99.78 \\
.14 \\
\end{array}$ \\
\hline & 99.78 & & 99.64 \\
\hline & \multicolumn{3}{|c|}{ Trace-element content (ppm) } \\
\hline $\begin{array}{l}\mathrm{B} \\
\mathrm{Ba} \\
\mathrm{Be} \\
\mathrm{Co} \\
\mathrm{Cr}\end{array}$ & $\begin{array}{r}20 \\
3,000 \\
1 \\
10 \\
70\end{array}$ & $\begin{array}{r}9 \\
420 \\
2 \\
7 \\
22\end{array}$ & $\begin{array}{r}20 \\
300 \\
1 \\
15 \\
70\end{array}$ \\
\hline $\begin{array}{l}\mathrm{Cu} \\
\mathrm{Ga} \\
\mathrm{La}\end{array}$ & $\begin{array}{r}150 \\
50 \\
70 \\
10 \\
30\end{array}$ & $\begin{array}{l}30 \\
17 \\
45 \\
20 \\
15\end{array}$ & $\begin{array}{l}30 \\
30 \\
70 \\
10 \\
50\end{array}$ \\
\hline 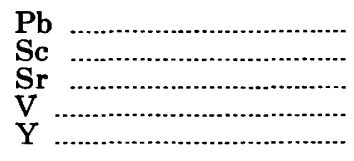 & $\begin{array}{r}10 \\
20 \\
1,500 \\
100 \\
20\end{array}$ & $\begin{array}{r}15 \\
4 \\
440 \\
88 \\
35\end{array}$ & $\begin{array}{r}10 \\
30 \\
2,000 \\
150 \\
20\end{array}$ \\
\hline $\begin{array}{l}\text { Yb } \\
\text { Zr }\end{array}$ & $\begin{array}{r}2 \\
150\end{array}$ & $140^{3.5}$ & $\begin{array}{r}3 \\
150\end{array}$ \\
\hline
\end{tabular}

1. 67ACx133: D101857: Biotite-hornblende quartz diorite porphyry Golden Zone stock.

2A. Average dacite (Nockolds, 1954).

2B. Average high-calcium granitic rock (Turekian and Wedepohl, 1961).

3. 67AHx233: D101858: Slightly altered hornblende-biotite quartz diorite porphyry, 2,000 feet west of the Golden Zone mine (opencut
Total sulfur determined by induction furnace compared to land rock phosphate standards by I. C. Frost. 
and K-feldspar. Hornblende fills most of the interstices between lagioclase laths; quartz and $\mathrm{K}$-feldspar are late and engulf or strongly embay the plagioclase.

\section{GRANITE AND GRANITE PORPHYRY}

Light-colored quartz-rich rocks with varietal biotite or muscovite form dikes and small stocks. The largest bodies are in the northern part of the district and at the stock in Ohio Creek that contains tin-bearing greisen. Long dikes of granitic rocks cut the dark clastic sedimentary rocks in the western part of the district and also cut the stock of garnetiferous diorite porphyry exposed west of Costello Creek. A small plug of granitic rock is at the Lookout Mountain mineral occurrence.

The granite to granite porphyry rocks range in texture from fine- to medium-grained and equigranular, as in the stocks or small plugs at Ohio Creek and upper Colorado Creek, to uniformly fine grained felsite, and to aphanitic groundmass porphyries, some of which have euhedral quartz phenocrysts.

The granite in the tin-bearing stock at Ohio Creek is white and sodic; it consists, in order of abundance, of albite-oligoclase, quartz, K-feldspar, and muscovite. Tourmaline is present locally as crystals in quartz veinlets and as disseminations in the stock. Semiquantitative analyses of typical samples of muscovite and tourmaline-bearing types show very low cencentrations of calcium, sodium about equal to or more than potassium, and abnormal amounts of tin and beryllium compared with most granite (table 2).

TABLE 2.-Semiquantitative spectrographic analyses of granite from the Ohio Creek tin-bearing stock

[Analyst: Chris Heropoulos. Analyses are reported in the series 0.1, 0.15, 0.2, $0.3,0.5,0.7,1.0,1.5$, and so on. Major elements in percent, minor elements in parts per million. $N=$ not detected. Looked for but not found: As, Au, Bi, Cd, Co, La, Mo, Ni, Pd, Pt, Sb, Sc, Te, U, V, W, and $\mathrm{Zn}]$

\begin{tabular}{|c|c|c|c|c|c|c|}
\hline \multicolumn{3}{|c|}{ Major elements } & \multicolumn{4}{|c|}{ Minor elements } \\
\hline & $\underset{\text { Mranite }}{\text { Muscovite }}$ & $\begin{array}{c}\text { Tourmaline } \\
\text { granite }\end{array}$ & & $\underset{\text { granite }}{\text { Muscovite }}$ & $\begin{array}{c}\text { Tourmaline } \\
\text { granite }\end{array}$ & ${ }^{1}$ Granite \\
\hline $\begin{array}{l}\mathrm{Si} \\
\mathrm{Al} \\
\mathrm{Fe} \\
\mathrm{Ca} \\
\mathrm{Mg} \\
\mathrm{K} \\
\mathrm{Na} \\
\mathrm{Ti}\end{array}$ & $\begin{array}{c}>10 \\
7 \\
.5 \\
.2 \\
.03 \\
2 \\
\quad 3 \\
\quad .007\end{array}$ & $\begin{array}{c}>10 \\
7 \\
.3 \\
.3 \\
.02 \\
3^{.02} \\
\quad .003\end{array}$ & $\begin{array}{l}\mathrm{Ag} \\
\mathrm{B} \\
\mathrm{Ba} \\
\mathrm{Be} \\
\mathrm{Cr} \\
\mathrm{Cu} \\
\mathrm{Ga} \\
\mathrm{Nb} \\
\mathrm{Pb} \\
\mathrm{Sn} \\
\mathrm{Y} \\
\mathrm{Zr}\end{array}$ & $\begin{array}{c}<0.7 \\
15 \\
50 \\
7 \\
\mathrm{~N} \\
3 \\
50 \\
20 \\
10 \\
20 \\
20 \\
20\end{array}$ & $\begin{array}{c}<0.7 \\
1,000 \\
70 \\
15 \\
1 \\
15 \\
30 \\
50 \\
30 \\
10 \\
15 \\
10\end{array}$ & $\begin{array}{c}0.037 \\
10 \\
840 \\
3 \\
4.1 \\
10 \\
17 \\
21 \\
19 \\
3 \\
40 \\
175\end{array}$ \\
\hline
\end{tabular}

'Low-calcium granitic rocks, Turekian and Wedepohl, 1961.

\section{STRUCTURE}

The Upper Chulitna district is on the southeast flank (Reed, 1961, p. A19) of the Alaska Range synclinorium (Brooks, 1911, p. 111). Rock units of the district parallel the axis of the range; the units complexly folded and faulted but generally in a homoclinal sequence. In general, they are in stratigraphic order from southeast to northwest and, except for the southeast-dipping pre-Permian rocks, dip northwest toward the axis of the synclinorium. Axial planes of asymmetric folds of Permian to Paleocene(?) rocks dip about $50^{\circ}$ or more into the range. Brooks (1911, p. 111) believed the general southeast dip of the prePermian rocks to be fault controlled; the authors concur generally and believe that the older rocks exposed near the broad valley of the Chulitna are in a horst or are the faulted crest of a major anticlinorium.

Major faults of the district strike about N. $40^{\circ}-50^{\circ}$ E. and make an acute angle with the McKinley strand of the major Denali fault (Grantz, 1966) this is exposed a few miles north of the district.

\section{FOLDS}

Although some units are repeated and infolded into other units, the general structure of the district is the homoclinal northwesterly dip toward the axis of the Alaska Range synclinorium. Second-order features on the homocline are major folds of the Upper Chulitna district, which are asymmetric and locally disharmonic anticlines and synclines. These folds generally plunge northeastward at a low angle; they are shown on the map (pl. 1) in the outcrop patterns of Permian and predominantly Mesozoic rocks. They are easily visualized in cross section (section A-A'; pl. 1). Small-scale folds are recognizable in the mainly southeast-dipping pre-Permian rocks near the valley of the Chulitna River, but large-scale folds are not evident, possibly because of the lack of good marker beds.

The larger folds of the Permian and Mesozoic rocks have wavelengths of approximately 1 mile and amplitudes of at least several thousand feet. In general, as shown by the cross section, they have one normal and one overturned limb. Where good marker units are present, it is obvious that the limbs of the folds are tightly drag folded. In places the more competent units have broken and disharmonic fold patterns resulted. Folds are present but are generally not mappable in the red-bed sequence, and probably the same type or more complex folds characterize the incompetent argillite-rich middle and upper Mesozoic sequence.

Because of intensive faulting and poor exposures, the relations of the folds in the northeastern part of the district near the West Fork of the Chulitna are uncertain. One fold, however, is partly exposed east of the Golden Zone mine and south of Lookout Mountain. The red siltstone and conglomerate which unconformably overlies the pre-Permian sequence has been 
deformed into an asymmetric fold whose axis lies about 1.5 miles east of the Golden Zone.

The coal-bearing rocks of the Costello Creek basin are predominantly flat lying, but near the edges of the basin they are warped to $45^{\circ}$ and locally nearly vertical. The warp was possible caused by drag on nearby faults.

\section{FAULTS}

Rocks of the district have been extensively broken by faults of dominant north-northeast strike. The major fault or fault zone, the Upper Chulitna fault zone, runs the length of the district (pl. 1); a second fault, is traceable for about 18 miles is the West District fault (pl. 1). The major faults are very near to major lithologic boundaries but in detail cut across them. The Upper Chulitna fault structure is near the boundary between the pre-Permian and the Mesozoic rocks, and the West District fault is near the lower contact of the interlayered limestone-pillow basalt unit. The drag along the fault walls indicates that the displacement on fault structures appears to be normal rather than reverse.

The Upper Chulitna fault zone is a complex structure. The zone trends about $\mathrm{N} .45^{\circ} \mathrm{E}$. from Eldridge Glacier to the ridge south of Ohio Creek. On the ridge north of Ohio Creek, the fault zone splits into two branches near Copeland Creek. The easterly branch follows an irregular course through Long Creek just west of Lookout Mountain; frem there it follows a nearly straight line $\mathrm{N} .35^{\circ}$ E. across the West Fork of the Chulitna into Costello Creek, where it is called the Lucrata segment (fig. 6A). The westerly branch strikes more northerly and connects with the Blind Creek fault zone mentioned by Ross (1933a, p. 307$308)$. This branch can be traced almost to the West Fork of the Chulitna.

The block of ground between the major branches of the Upper Chulitna fault north of Copeland Creek is broken by faults of north-northeast to north, northeast, and northwest strike. One of the faults of the set striking north-northeast to north is the Bryn Mawr fault (pl. 1). The Bryn Mawr fault bounds one side of a mass of highly altered rocks that in turn surrounds the small quartz diorite stock that is the host of the Golden Zone deposit. Vein fissures of the Lindfors, Mayflower, East, and other recognized mineralized faults lie in this block and are subparallel to the Bryn Mawr fault. Although the exposures are very poor, the Bryn Mawr fault apparently terminates in the north at a fault that strikes approximately N. $60^{\circ}$ E. and dips steeply to the northwest.

The Lucrata segment, exposed in Colorado and Costello Creeks, separates pre-Permian graywacke and argillite from a massive andesite tuff of the Permian(?) and Lower Triassic unit. Serpentinite and a quartz diorite porphyry dike are present along branches of the fault in Costello Creek.

In Costello Creek the fault zone is weakly sulfidized and contains local strongly mineralized cross-fault(?) structures, as at the Lucrata prospect. The Eagle vein is in subparallel faults in the wall of the Lucrata segment.

The West District fault has been studied chiefly in the Ohio Creek-Copeland Creek area. This fault and closely related structures extend at least as far south as Eldridge Glacier and almost as far north as the West Fork of the Chulitna. South of McCallie Creek, the fault generally separates the limestone-pillow basalt unit from older strata; northward, the inferred trace of the fault is in limestone-basalt; at a point about 2 miles north of Ohio Creek, the fault separates limestone-basalt from the dark-colored argillite-rich sequence. Beyond Copeland Creek, the fault is entirely in the argillite-rich sequence. The fault is high angle and generally dips northwest.

Faults that strike northwest are exposed east of the Golden Zone and near the Costello Creek coal field. At both places they appear to be relatively young, for they displace northeast-striking faults and, near Costello Creek, coal-bearing beds.

\section{GEOLOGIC HISTORY}

Sometime before the Permian, possibly in the Devonian, marine sediments accumulated in a shallow basin near the site of the present Chulitna valley. These sediments were lithified, folded, weakly metamorphosed, and beveled by erosion before the deposition of sediments in the Permian and later.

The next period of sedimentation probably began in the Permian, continued into the Triassic, and possibly continued through the Jurassic into the Paleocene. Although there were probably numerous breaks in the late Paleozoic and Mesozoic sedimentation, the most obvious breaks are above the pre-Permian and below the Oligocene coal-bearing strata. Red beds, basalt, and limestone of Permian(?) and Triassic age accumulated in a shallow basin. The red-bed sequence is similar in several respects to other red beds of Permian and Triassic age that accumulated in fault-controlled basins. The size of the sequence, which is as much as 3 feet across, and the angularity of some clasts suggest derivation from a nearby upfaulted terrane, probably from rocks southeast of the present Upper Chulitna fault zone. Limestones in the Permian(?) and Triassic sequence and pillow lavas, however, reflect marine conditions with attendant volcanism. The ammonites of Early Triassic age, in particular, indicate the basin had connections with the open sea. 
The basin deepened and probably enlarged during Jurassic(?) and Cretaceous time but was folded and uplifted by Paleocene time when the conglomerates of the Cantwell Formation were formed in the central Alaska Range. Strong faulting occurred either nearly synchronous with the folding or, more probably, slightly later; the faulting was followed by the emplacement of intrusive igneous rocks and by the formation of hypogene ore deposits.

Prior to the Oligocene, the rocks were again beveled by erosion, and during the Oligocene sandy and coalbearing sediments accumulated in minor basins. Some faulting occurred after deposition of the coals.

\section{MINERAL DEPOSITS AND OCCURRENCES}

Most of the mineral deposits and occurrences of the district are epigenetic deposits of gold or copper characterized by abundant arsenopyrite. Small syngenetic occurrences of chromite or chromium- and nickelbearing silicates are found in some of the ultramafic rocks. Small placer deposits of gold occur in drainages of the district. The largest bodies of mineralized rock are a vein-disseminated type; they occur in porphyry or in locally contact metamorphosed argillite-basalt and limestone hosts. The most important prospect of the district, the Golden Zone, is in a breccia pipe in porphyry.

The dominant ores of the district are arsenopyrite, chalcopyrite, pyrrhotite, pyrite, sphalerite, and galena; less common ores include stibnite, cassiterite, molybdenite, and bismuthinite. Quartz and iron-bearing carbonates are the main gangue minerals. The ore deposits are commonly enveloped by weakly propylitized mafic igneous hosts, bleached and silicified hornfels, and moderately to strong sericitized porphyry. Most deposits and occurrences are apparently of low to moderate grade, gold and copper are generally the most valuable metals. Silver is locally abundant, and tin and some rarer elements are of potential economic value in some of the epigenetic occurrences.

The minerals and alteration products of most deposits indicate that the ore formed at moderate to high temperatures, but the minerals occurring in the hypabyssal rocks suggest relative shallow emplacement.

\section{CLASSIFICATION AND GENERAL DESCRIPTION OF} TYPES OF DEPOSITS

The mineral deposits of the district were classified primarily on the basis of structure and secondly on the basis of other criteria such as mineral or metal content. Classification by type is given, with examples, in table 3. Actually, there may be all gradations between the main types, but the examples given correspond closely to their type.
TABLE 3.-Classification of epigenetic lode deposits of occurrences of the Upper Chulitna district, with examples

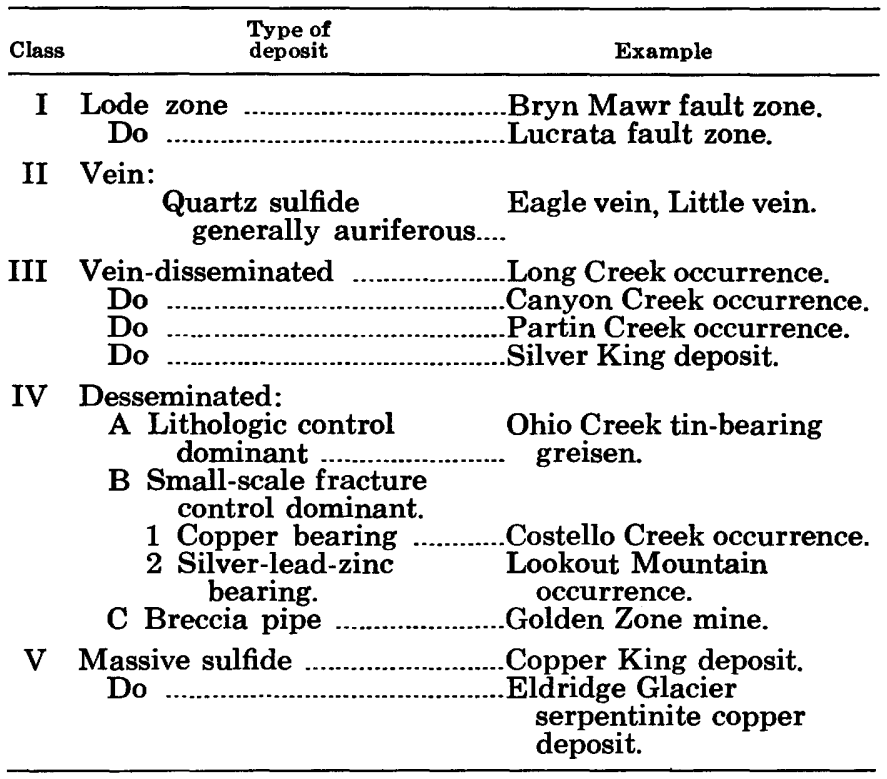

The lode (or shear) zone deposits are bodies of weakly sulfidized rock 50 or more feet wide that occupy major fault zones of the region. Two such occurrences are fairly well exposed: one in Bryn Mawr Creek, the other in Costello Creek near the Lucrata prospect. The rocks in the hanging wall of the fault zone exposed in Bryn Mawr Creek, about 3,000 feet below the Golden Zone deposit, are red siltstones; on the footwall and in the fault zone itself, the same rock is bleached and weakly sulfidized and is cut by small vein deposits. The mineralized zone on the footwall has no definite boundary. The part exposed in a small gulch near the crosscut adit (500-foot level) of the Golden Zone is about 200 feet wide; and the part exposed in Bryn Mawr Creek, 1,000 feet to the south, is about 80 feet wide and is more strongly sheared and sulfidized than the adjacent footwall rocks (pl. 2). The Bryn Mawr fault can be traced or projected reasonably for about $21 / 2$ miles, and scattered exposures suggest that at least the middle 6,000 feet is weakly sulfidized. The grade of the altered and sulfidized minerals in the Bryn Mawr fault is very low; but gold, silver, copper, arsenic, lead, tin, and zinc are present in anomalous amounts in samples from the fault zone (samples $8-9$, pl. 2, samples 23B-25B, pl. 2).

The Lucrata segment of the Upper Chulitna fault zone is exposed in and along Costello Creek north of the West Fork of the Chulitna River just south of the Dunkle coal mine. The segment weakly sulfidized, is 50-100 feet wide, and is locally exosed or can be projected with confidence for about 2,000 feet near Costello Creek. The fault zone can reasonably be projected 
for about another 7,000 feet southwestward to a prominent fault zone of serpentinite and quartz diorite porphyry that is exposed in Colorado Creek (fig. 6). Random chips taken across the zone at two places (Nos. 1A and 5A respectively, fig. 6A), show in ppm: (1) 0.1 gold, 5 silver, and 500 copper; and (2) 0.1 gold, 2 silver, and 500 copper. Trace amounts of bismuth were present in both samples.

Neither the Bryn Mawr nor the Lucrata lode zone is strongly mineralized where sampled, but the parallel and cross veins of both lode zones are. It is possible that the shear zones themselves could be strongly mineralized locally.

Vein deposits occur in parallel and cross veins in the major shear zones or lodes, in fissures with disseminated sulfides in adjacent basalt, conglomerate, or limestone hosts, and in weakly mineralized or altered wall rocks. Two deposits, the Eagle and Little veins, are typical vein deposits that are not associated with sulfides disseminated in host rocks.

The Eagle vein, exposed in Costello Creek near the Lucrata lode or shear zone, can be traced for about 700 feet and can be projected reasonably for about twice that distance. Apparently the vein splits in the southwest because there are at least two main branches near the old Eagle prospect adit described by Ross (1933a, p. 329-330). The vein has a maximum width of about 4 feet; it contains arsenopyrite pods as much as 1 foot wide and quartz-rich masses as much as 2.5 feet in diameter. Three assays of the arsenopyrite-quartz vein taken during our investigation showed $6.6,15$, and 38 ppm gold and $100-500 \mathrm{ppm}$ silver. The walls of the deposit which are basalt and gabbro or serpentinite, are not strongly sulfidized although basalt nearby contains a trace of gold and as much as $1,000 \mathrm{ppm}$ copper.

The Little vein, also described by Ross (1933a, p. $324)$, strikes north-northeast and is exposed in porphyry walls south of the Golden Zone breccia pipe. It can be followed with certainty for approximately 300 feet. Ross notes that it may have been traced for as far as 1,000 feet by pits now caved. Strongly sulfidized material exposed in pits on the vein is as much as 1-foot wide, and the width of the vein itself probably averages as much as 3 feet. In samples taken during our investigation and during earlier Survey studies, gold ranged from 0.16 to $2.58 \mathrm{oz}$ per ton and silver from 2.4 to 11.60 oz per ton.

Structurally similar veins that are exposed in the Banner claims include the Mayflower and East veins, individual veins in the Lindfors group, and the Blind Creek shear zone.

Vein-disseminated deposits are found at Long Creek, Partin Creek, Canyon Creek, and at the Silver King prospect. These deposits are in contact metamorphosed argillite (Silver King and Long Creek) or argillitebasalt-limestone wallrocks (Canyon Creek and Partin Creek) ; the disseminated sulfides occur on fracture surfaces in hornfels and on fracture surfaces and in vesicles in basalt. On the basis of limited sampling, the disseminated deposits contain trace amounts of gold and silver and copper which are generally measured within the range of $0.0 x$ to $0 . x$ percent.

Sulfides are present on fracture surfaces and are very sparsely disseminated in porphyry at a deposit east of Costello Creek and near Lookout Mountain. Disseminated sulfides also occur in altered parts of the quartz diorite stock at the Golden Zone deposit, but the main deposit is in a vertically plunging breccia pipe about 200-300 feet in diameter. The outer part of the breccia pipe is strongly broken and brecciated and is composed of rotated blocks cemented by sulfides; the inner part is shattered and sulfides are disseminated throughout and are present on fracture surfaces.

The one known greisen occurrence of the district (Ohio Creek) is mainly the disseminated type. Few to moderately abundant grains of arsenopyrite and few very fine grains of cassiterite are disseminated in quartz-muscovite greisen and in veinlike bodies marginal to the Ohio Creek tin-bearing greisen.

Parts of several deposits approach massive sulfide form. The best examples of such deposits, which have sulfide-rich pods 2-3 feet wide, are to be found in the Copper King deposit and in a serpentinite deposit just north of Eldridge Glacier. The massive deposits are rich in copper (locally 5 percent) and contain detectable amounts of precious metals.

\section{DISTRIBUTION}

The epigenetic mineral deposits and occurrences are scattered throughout the Upper Chulitna district but are most abundant in two areas: In the northern part, from approximately $1 / 2$ mile south of Long Creek northward to Camp Creek; in the southwest part, from Partin Creek to Canyon Creek. Geochemical anomalies, particularly in Shotgun and McCallie Creeks (Hawley and others, 1969), suggest that there are other metallized rocks between Partin Creek and Canyon Creek. Epigenetic copper that is found at scattered localities in the main serpentinite deposit trend in and near the Upper Chulitna fault zone in the southern part of the district.

The mineralization of the entire district and of the adjacent Yentna district to the southwest apparently is related to the strong northeasterly structural alinement of the district, especially to deep fault structures. Most deposits are in the hanging walls of the Upper Chulitna and the West District faults, in favorable rock units, or on subsidiary fault structures. The Golden 
Zone-Silver King area, which has a very complex structural pattern, is most strongly mineralized between the major branches of the Upper Chulitna fault in the area of the Bryn Mawr fault.

Most deposits are spatially associated with hypabyssal porphyritic rock of dioritic to granitic composition. The density of deposits correlates to some extent with the density of distribution of the hypabyssal intrusives, as, for example, in the strongly mineralized northern part of the district. The Golden Zone deposit is approximately in the center of a quartz diorite plug, and the Silver King, Copper King, Long Creek, Camp Creek, and Costello Creek deposits or occurrences are either in porphyry or adjacent to complex groups of small porphyry dikes. The Ohio Creek tin-bearing greisen is within a granite stock. A very small mass of quartz diorite porphyry crops out in the Partin Creek occurrence (not shown on pl. 1). Although no porphyry was seen at the Canyon Creek deposit, its high tin content and its proximity to the igneous-centered Ohio Creek tin-bearing deposit suggest that the deposit could reflect an underlying pluton.

\section{MINERALOGY}

The major metallic minerals of the district are arsenopyrite, pyrite, and chalcopyrite; pyrrhotite is abundant locally, and gold, partly in native form, is the most valuable metal. Other metallic minerals are: sphalerite, galena, stibnite, molydenite, chalcocite, argentite, and bismuthinite. Oxide minerals are cassiterite and wodginite from the Ohio Creek greisen, and ilmenite and chromite from mafic and ultramafic intrusives.

Arsenopyrite, which is present in nearly all epigenetic deposits of the district, was not found in the Copper King deposit. It occurs in massive form in vein or open-space fillings in fissures and breccias and in disseminated form in the walls of the deposits. In disseminated form its occurrence is similar to pyrite of the sulfidized rocks of many other mineralized areas. Veins or breccia fillings consisting mostly of arsenopyrite are found at the Eagle, Lucrata, Silver King, Riverside, Little Vein, Golden Zone, Long Creek prospect, Ready Cash, and nearby occurrences in Canyon Creek, in Ohio Creek tin-bearing greisen, and in Partin Creek.

Pyrite is present locally but is generally not as abundant as arsenopyrite in the auriferous or copper-bearing deposits. At the Golden Zone deposit, pyrite occurs as euhedral crystals, as massive fracture fillings in arsenopyrite, and as colloform incrustations in open spaces. Colloform pyrite fills open spaces in fractured sulfides at the East vein.

Chalcopyrite is abundant at the Copper King prospect, at an occurrence in serpentinite walls north of Eldridge Glacier, and locally at the Ready Cash and
Golden Zone deposits. It is present in small amounts in most copper-bearing rocks of the district. At the Golden Zone deposit, it is in open-space filling of breccia material; at the Copper King prospect and serpentinite occurrence, in desseminated to massive form. It is present in disseminated form and as vesicle fillings in basalt host rocks of the Canyon Creek and Partin Creek occurrences.

Pyrrhotite is a major constituent of the Copper King prospect aind is widely disseminated in basalt at Partin Creek. It is disseminated in hornfels at and near the Silver King prospect and is disseminated in gabbro near the Lucrata prospect.

Sphalerite is present in the Golden Zone deposit and East veins, in the Ready Cash prospect, and in the Long Creek prospect. The sphalerite in the Golden Zone deposit is almost black and occurs with chalcopyrite in open-space filling.

Galena is not nearly as common as the above minerals. It is present in some veins in the Golden Zone area, and is disseminated in the Lookout Mountain occurrence. Near the Ready Cash prospect it occurs abundantly in both massive sulfide and quartz-rich veins.

Stibnite was observed only at and near the Silver King prospect but has been reported from the Golden Zone deposit, Eagle Vein, and Partin Creek occurrences by Capps (1919), Ross (1933a), and F. L. Thurmond (unpubl. data, 1918).

Chalcocite, argentite, and molydenite are known from at least one place in the district. In polished section chalcocite is seen as thin rims around chalcopyrite and in veinlets and blebs in chalcopyrite from the Golden Zone deposit. Argentite was reported by Ross (1933a, p. 313) from the Ready Cash deposit. Molybdenite was observed near the Copper King prospect and probably occurs in parts of the Golden Zone and Silver King prospects.

Bismuthinite has been identified in a placer concentrate from near the Silver King (Ross, 1933a). The abundance of bismuth in assays from the Long Creek prospect and locally at the Golden Zone and nearby veins suggests that bismuthinite or other discrete bismuth minerals are more widely distributed than presently known.

Native gold has been found in placer prospects in Bryn Mawr Creek below the Golden Zone and in the lower part of Shotgun Creek. It also is found in small amounts in other stream sediments. Gold in native form though not seen in lode deposits, almost certainly exists.

Cassiterite occurs as very dark brown grains, mainly less than 100-mesh size, in the greisen from Ohio Creek. It is less abundant in a heavy mineral fraction than arsenopyrite. Cassiterite has also been reported from 
the Golden Zone deposit (Walter Gnagy, U.S. Bureau of Mines, written commun., 1967); from the concentrations of tin found analytically, cassiterite or another discrete tin mineral should occur at the Long Creek prospect, in the Canyon Creek area, and probably at several other prospects in the district.

Wodginite, a rare mineral related to columbitetantalite (Nickel and others, 1963), occurs with cassiterite in the greisen from Ohio Creek. R. G. Wehr identified wodginite and cassiterite by their X-ray diffraction patterns. The presence of wodginite was confirmed by an X-ray fluorescent analysis of the diffraction plate which revealed abundant niobium and tantalum. The mineral was identified in only the one sample from Ohio Creek and is less abundant in that sample than cassiterite.

Chromite was found as a few disseminated grains in serpentinite and in one massive occurrence (pl. 1). The massive chromite has been strongly sheared; in polished section, lensoidal masses of chromite as much as 2 inches long are seen to be enclosed in a matrix of crushed chromite-rich material.

Ilmenite was noted as disseminations in fine-grained gabbro, particularly in the uppermost gabbro body at Long Creek (pl. 1).

Generally oxidation of ore minerals has not been important in the district. Scorodite is present locally and can be abundant on arsenopyrite-bearing veins; but remnants of unaltered arsenopyrite can be found, even on surface materials. Limonites of various kinds are present. Jarositic limonite is well developed in the canyon of Bryn Mawr Creek, and dark-brown copperbearing limonite is found at the Golden Zone and Copper King prospects. Malachite was noted in the Canyon Creek area and at a copper occurrence in serpentinite near Eldridge Glacier; azurite and malachite coat the deposit at the Golden Zone.

\section{METAL CONTENT}

Chemical analyses show that epigenetic mineral deposits and disseminated occurrences of the district are generally enriched in several metals relative to common rocks of the earth's crust. These metals include the rock-forming element, iron; the relatively abundant trace metals, copper, lead, and zinc; and the rarer metals, antimony, arsenic, bismuth, gold, molybdenum, silver, and tin. Results of the analyses of Turekian and Wedepohl (1961, table 2), given here for comparison with our data below, indicate that iron is present in most common rocks from 1 to 9 percent; copper, lead, and zinc, about 0.001 to 0.01 percent (10 to $100 \mathrm{ppm}$ ); and the rare metals, about $0.00 \mathrm{x}$ ppm for gold to about $1 \mathrm{ppm}$ for other metals. Arsenic and gold are the most diagnostic of the rarer trace metals, although, because of local zoning or unknown factors, they are not everywhere strongly enriched.

Data on the metal content of mineralized rocks in the district are summarized in two tables: analyses of representative veins and breccia deposits in the district in table 4 , analyses from disseminated occurrences and deposits in table 5. Analyses 1-13 of table 4 are of veins or breccia materials that contain more than 1 percent $(>10,000 \mathrm{ppm})$ arsenic. Samples of these mineralized rocks almost invariably contain anomalous concentrations of gold, silver, antimony, bismuth, and copper; and some rocks also contain lead and zinc. Tin was present in noticeable concentrations in several samples, particularly in deposits from the Long Creek prospect south (Nos. 7-12). Gold is present only in trace amounts in samples from pegmatitic quartz-arsenopyrite veins of the Ohio Creek tin deposit (No. 12) and in very small quantities in two veins from the Canyon Creek area, but most arsenopyrite-rich veins contain $1.0 \mathrm{ppm}$ or more. Some, for example, sample Nos. 1, 2, $3 \mathrm{~B}, 6,7$, and 11 , are moderate- to high-grade gold ores. These and other data suggest that the gold content of arsenopyrite-rich samples is fairly constant in some deposits, but varies widely in others. Analyses from samples collected or reported by Ross (1933a) and others from the Eagle, Lucrata, and Little Vein deposits indicate a fairly consistent content of gold of $1 / 2$ ounce to more than 1 ounce gold per ton. Samples from the Long Creek deposit (9A-C) average about $3 \mathrm{ppm}$, but samples (3A-C) from the Silver King vary widely. Approximately 10 arsenic-rich samples collected throughout the district ranged from about $1 \mathrm{ppm}$ to more than $200 \mathrm{ppm}$.

Analysis No. 13 (table 4) represents well-mineralized arsenic-rich rock from the Golden Zone deposit and suggests a general equivalence in composition of arsenopyrite-rich breccia filling with the more common arsenopyrite-bearing veins. Partial quantitative assays of mineralized rocks from the Golden Zone emphasize the abundance of arsenic at the deposit; the analyses below are from composite channel samples used for mill tests which were reported by Mulligan, Warfield, and Wells (1967) :

\begin{tabular}{|c|c|c|c|c|c|c|c|}
\hline & $\begin{array}{l}\text { Gold } \\
\text { (oz.pe }\end{array}$ & $\begin{array}{l}\text { Silver } \\
\text { rton) }\end{array}$ & Iron & Arsenic & $\begin{array}{c}\text { Copper } \\
\text { (percent) }\end{array}$ & Lead & Zine \\
\hline 100 -foot lev & .0 .18 & 3.4 & 10.4 & 4.1 & 0.97 & 0.05 & 0.32 \\
\hline 200-foot level & $\ldots .23$ & 1.25 & 9.5 & 14.9 & .24 & .05 & .05 \\
\hline
\end{tabular}

Analyses of samples 14-21 (table 4) represent ores from a stibnite-bearing vein, some quartz veins, and other types of mineralized rocks. Two samples (Nos. 20-21) are from massive sulfide deposits where copper is the dominant economic metal present. The quartz veins have very low metal contents, but arsenic is present in the analyses shown. 
TABLE 4.-Analyses of veins, breccia, and massive sulfide deposits

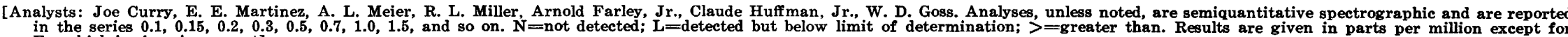
$\mathrm{Fe}$, which is given in percent]

\begin{tabular}{|c|c|c|c|c|c|c|c|c|c|c|c|c|c|c|c|}
\hline $\begin{array}{c}\text { Sample } \\
\text { No. }\end{array}$ & $\begin{array}{l}\text { Lab. } \\
\text { No. }\end{array}$ & $\begin{array}{c}\text { Field } \\
\text { No. }\end{array}$ & $\mathbf{A g}$ & As & $\mathbf{A u}^{1}$ & $\mathbf{B i}$ & Co & $\mathrm{Cu}$ & Mo $\mathrm{Ni}$ & $\mathbf{P b}$ & $\mathrm{Sb}$ & Sn & $\mathrm{Zn}$ & $\mathrm{Fe}$ & Location and host rock \\
\hline \multicolumn{16}{|c|}{ Arsenopyrite-rich veins } \\
\hline $\begin{array}{c}1 \\
2 \\
3 \mathrm{~A} \\
\mathbf{B} \\
\mathbf{C}\end{array}$ & $\begin{array}{r}\text { ACK 033 } \\
010 \\
\text { ACL } 014 \\
\text { ACK 018 } \\
\text { AGJ } 673\end{array}$ & $\begin{array}{c}67 \mathrm{AC} \times 181 \\
136 \\
296 \mathrm{E} \\
162 \\
\text { HB6-6M70 }\end{array}$ & $\begin{array}{r}300 \\
100 \\
3 \\
50 \\
7\end{array}$ & $\begin{array}{l}>10,000 \\
>10,000 \\
>10,000 \\
>10,000 \\
>10,000\end{array}$ & $\begin{array}{c}38 \\
50 \\
10 \\
200 \\
1.0\end{array}$ & $\begin{array}{r}30 \\
1,000 \\
300 \\
>1,000 \\
50\end{array}$ & $\begin{array}{r}15 \\
300 \\
700 \\
150 \\
150\end{array}$ & $\begin{array}{r}700 \\
700 \\
500 \\
300 \\
1,500\end{array}$ & $\begin{array}{lll}\mathbf{N} & 200 \\
N & 30 \\
N & 30 \\
N & 5 \\
L & 70\end{array}$ & $\begin{array}{r}1,500 \\
700 \\
20 \\
200 \\
70\end{array}$ & $\begin{array}{r}7,000 \\
700 \\
200 \\
200 \\
500\end{array}$ & $\begin{array}{l}\mathbf{N} \\
\mathbf{N} \\
\mathbf{N}_{70} \\
15\end{array}$ & $\begin{array}{l}1,500 \\
L \\
N \\
N \\
200\end{array}$ & $\begin{array}{l}7 \\
20 \\
15 \\
15 \\
20\end{array}$ & $\begin{array}{l}\text { Eagle vein. } \\
\text { Lucrata prospect. Gash (?) vein in major shear zone. } \\
\text { Silver King. Vein in sulfidized breccia near Colorado Creek. } \\
\text { So. } \\
\text { Silver King. Arsenopyrite vein main prospect area (fig. 6B). }\end{array}$ \\
\hline $\begin{array}{l}\mathbf{4} \\
\mathbf{5} \\
\mathbf{6} \\
7 \\
\mathbf{8}\end{array}$ & $\begin{array}{r}\text { ACF } 065 \\
090 \\
021 \\
118 \\
004\end{array}$ & $\begin{array}{r}81 \mathrm{~b} \\
109 \\
67 \mathrm{AH} \times \operatorname{III} 5 \mathrm{~A} \\
45 \\
111\end{array}$ & $\begin{array}{r}3 \\
10 \\
30 \\
30 \\
150\end{array}$ & $\begin{array}{r}>10,000 \\
>10,000 \\
>10,000 \\
>10,000 \\
>10,000\end{array}$ & $\begin{array}{r}4.8 \\
8.4 \\
36.0 \\
25.0 \\
4.0\end{array}$ & $\begin{array}{r}50 \\
100 \\
15 \\
200 \\
10\end{array}$ & $\begin{array}{l}70 \\
15 \\
10 \\
\mathbf{N}\end{array}$ & $\begin{array}{r}500 \\
700 \\
2,000 \\
300 \\
500\end{array}$ & $\begin{array}{ll}\mathbf{N} & 7 \\
\mathbf{N} & \mathbf{L} \\
\mathbf{N} & 15 \\
\mathbf{N} & \mathbf{N} \\
\mathbf{N} & \mathbf{5 0}\end{array}$ & $\begin{array}{r}\mathbf{L} \\
100 \\
500 \\
5,000 \\
15,000\end{array}$ & $\begin{array}{r}700 \\
700 \\
500 \\
700 \\
>10,000\end{array}$ & $\begin{array}{l}\frac{N}{N} \\
N_{N}^{15}\end{array}$ & $\begin{array}{c}\mathbf{N} \\
\mathbf{N} \\
\mathbf{L} \\
\mathbf{N} \\
10,000\end{array}$ & $\begin{array}{r}10 \\
10 \\
3 \\
15 \\
10\end{array}$ & $\begin{array}{l}\text { Golden Zone area, Unamed vein. } \\
\text { Golden Zone area, Little vein. } \\
\text { Lindfors vein. }\end{array}$ \\
\hline $\begin{array}{r}9 \mathrm{~A} \\
\mathbf{B} \\
\mathbf{C} \\
10 \mathrm{~A} \\
\mathbf{B}\end{array}$ & $\begin{array}{r}\text { AGJ } 809 \\
816 \\
827 \\
979 \\
591\end{array}$ & $\begin{array}{r}68 \mathrm{ACk} 230 \mathrm{~A} \\
230 \mathrm{H} \\
230 \mathrm{~S} \\
57-\mathrm{H9} \\
\mathrm{M} 814\end{array}$ & $\begin{array}{r}500 \\
100 \\
700 \\
150 \\
10\end{array}$ & $\begin{array}{l}>10,000 \\
>10,000 \\
>10,000 \\
>10,000 \\
>10,000\end{array}$ & $\begin{array}{r}2.8 \\
3.1 \\
3.2 \\
.3 \\
.3\end{array}$ & $\begin{array}{r}300 \\
150 \\
150 \\
30 \\
15\end{array}$ & $\begin{array}{r}70 \\
150 \\
10 \\
15 \\
70\end{array}$ & $\begin{array}{l}3,000 \\
3,000 \\
3,000 \\
7,800 \\
100\end{array}$ & $\begin{array}{rr}0 & 7 \\
0 & 70 \\
07 & 70 \\
0 & 7 \\
0 & 70 \\
10 & 50\end{array}$ & $\begin{array}{l}3,000 \\
1,000 \\
3,000 \\
1,000 \\
100\end{array}$ & $\begin{array}{r}3,000 \\
1,500 \\
2,000 \\
100 \\
500\end{array}$ & $\begin{array}{l}100 \\
10 \\
700 \\
300 \\
150\end{array}$ & $\begin{array}{c}>10,000 \\
300 \\
>10,000 \\
7,000 \\
\quad \mathrm{~L}\end{array}$ & $\begin{array}{r}20 \\
>20 \\
>20 \\
15 \\
15\end{array}$ & $\begin{array}{ll}\text { Long Creek prospect. Quartz-arsenopyrite vein. } & \begin{array}{l}\text { Do. } \\
\text { Do. }\end{array} \\
\text { Canyon Creek occurrence. } & \text { Do. }\end{array}$ \\
\hline $\begin{array}{l}11 \\
12\end{array}$ & $\begin{array}{l}\text { ACL } 510 \\
\text { AGJ } 978\end{array}$ & $\underset{57-6 \mathrm{I}}{\mathrm{Cx} 344 \mathrm{H}}$ & $\begin{array}{r}1 \\
20\end{array}$ & $\begin{array}{l}>10,000 \\
>10,000\end{array}$ & ${ }^{63} .04$ & $\begin{array}{r}100 \\
20\end{array}$ & $\begin{array}{r}700 \\
\mathbf{N}\end{array}$ & $\begin{array}{l}7,000 \\
1,000\end{array}$ & $\begin{array}{rr}30 & 50 \\
\mathbf{L} & 7\end{array}$ & $\begin{array}{l}100 \\
300\end{array}$ & $\begin{array}{r}7,000 \\
150\end{array}$ & $\underset{>1,000}{\mathrm{~N}}$ & $L^{300}$ & 20 & $\begin{array}{l}\text { Partin Creek occurrence. } \\
\text { Ohio Creek tin-grreisen deposit. Quartz-arsenopyrite. } \\
\text { vein at contact of granite stock. }\end{array}$ \\
\hline \multicolumn{16}{|c|}{ Arsenopyrite-rich breccia } \\
\hline 13 & ACF 116 & $67 \mathrm{AHx} \quad 42$ & 1105 & $>10,000$ & 214.8 & 50 & $\mathrm{~L}$ & $>5,000$ & $\mathbf{N} \mathrm{L}$ & 700 & 500 & 50 & 2,000 & 15 & Golden Zone, breccia exposed in main opencut. \\
\hline \multicolumn{16}{|c|}{ Other veins and massive sulfide deposits } \\
\hline $\begin{array}{l}14 \\
15 \\
16 \\
17 \\
18\end{array}$ & $\begin{array}{r}\text { ACL } 019 \\
\text { ACF } 012 \\
068 \\
\text { AGJ } 853 \\
965\end{array}$ & $\begin{array}{c}67 \mathrm{ACx} 298 \\
67 \mathrm{AHX} 128 \mathrm{~B} \\
196 \\
36-\mathrm{H} 17 \\
512-\mathrm{H} 7 \mathrm{~A}\end{array}$ & $\begin{array}{c}10 \\
100 \\
0.5 \\
2 \\
\mathbf{N}\end{array}$ & $\begin{array}{c}7,000 \\
>10,000 \\
L \\
1,000 \\
L\end{array}$ & $\begin{array}{c}23 \\
4.2 \\
.06 \\
.9 \\
\mathbf{N}^{-9}\end{array}$ & $\begin{array}{l}\mathrm{L}^{10} \\
\mathbf{N} \\
\mathbf{N}\end{array}$ & $\begin{array}{c}7 \\
10 \\
\mathbf{L} \\
\mathbf{N} \\
\mathbf{N}\end{array}$ & $\begin{array}{r}200 \\
500 \\
20 \\
\mathrm{~N}^{20}\end{array}$ & $\begin{array}{lr}\mathbf{N} & 30 \\
N & 50 \\
N & 7 \\
N & 15 \\
N & 7\end{array}$ & $\begin{array}{l}300 \\
15,000 \\
\mathbf{N} \\
\mathbf{N} \\
\mathbf{N}\end{array}$ & $\begin{array}{l}>10,000 \\
1,000 \\
\mathbf{N} \\
\mathbf{N} \\
\mathbf{N}\end{array}$ & $\begin{array}{l}\mathbf{N} \\
100 \\
\mathbf{N} \\
\mathbf{N}\end{array}$ & $\begin{array}{c}1,500 \\
>10,000 \\
N \\
N \\
\mathrm{~L}\end{array}$ & $\begin{array}{c}7 \\
10 \\
2 \\
.7 \\
.3\end{array}$ & $\begin{array}{l}\text { Stibnite-pyrite vein 1,000 feet southwest of Silver King. } \\
\text { Golden Zone area. East vein. Sphalerite-galena-arsenopyrite. } \\
\text { Quartz vein. Limonitic. Blind Creek fault zone. } \\
\text { Quartz vein. Tungsten detected. }\end{array}$ \\
\hline $\begin{array}{l}19 \mathrm{~A} \\
20 \\
21\end{array}$ & $\begin{array}{r}977 \\
975 \\
\text { AGF } 097 \\
\text { AGJ } 878\end{array}$ & $\begin{array}{r}57-6 \mathrm{G} \\
6 \mathrm{D} \\
67 \mathrm{AHx} 218-2 \\
511-\mathrm{H} 6 \mathrm{C}\end{array}$ & $\begin{array}{l}70 \\
30 \\
50 \\
15\end{array}$ & $\begin{array}{l}\mathbf{3 0 0} \\
\mathbf{3 , 0 0 0} \\
\stackrel{N}{N}\end{array}$ & $\begin{array}{r}.02 \\
1.04 \\
.1\end{array}$ & $\begin{array}{r}\mathrm{N}_{30} \\
\mathrm{~N}^{100}\end{array}$ & $\begin{array}{r}\mathbf{N} \\
5 \\
70 \\
200\end{array}$ & $\begin{array}{r}150 \\
150 \\
20,000 \\
75,000\end{array}$ & 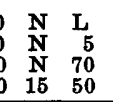 & $\begin{array}{r}30 \\
200 \\
\mathbf{L}_{10}\end{array}$ & $\begin{array}{l}\mathbf{N} \\
\mathbf{L} \\
\mathbf{N} \\
\mathbf{N}\end{array}$ & $\begin{array}{r}>1,000 \\
>1,000 \\
\mathrm{~N}^{30}\end{array}$ & $\begin{array}{l}\mathrm{L} \\
\mathrm{L} \\
300 \\
200\end{array}$ & $\begin{array}{l}1 \\
1.5 \\
10 \\
20\end{array}$ & $\begin{array}{l}\text { Greisen. Quartz-muscovite-arsenopyrite. Tungsten, } 50 \mathrm{ppm} \text {. } \\
\text { Greisen. Quartz-muscovite-arsenopyrite. Tungten, } 150 \mathrm{ppm} \text {. } \\
\text { Copper King. Massive pyrrhotite-chalcopyrite. } \\
\text { Eldridge Glacier. Copper oceurrence in serpentinite. }\end{array}$ \\
\hline & & & 0.5 & 200 & 0.02 & 10 & 5 & 5 & 52 & 10 & 10 & 100 & 200 & 0.05 & \\
\hline
\end{tabular}

${ }^{1}$ Atomic absorption.

ire assay-atomic absorption. 
Disseminated deposits of the district have a metal suite like that of the veins (table 5). Except for the disseminated deposit at Lookout Mountain, which is characterized by galena and sphalerite (Nos. 13-15), disseminated deposits generally contain pyrrhotite, arsenopyrite, chalcopyrite, and (or) pyrite and have been enriched in iron. Copper is slightly to moderately enriched in most deposits, and silver, gold, bismuth, antimony, and tin are detected locally. Except for the Lookout Mountain deposit and the disseminated material from the Golden Zone (Nos. 11-15), lead is not strongly enriched and in some deposits is at or below the common background levels of concentration.

\section{GEOCHEMISTRY OF STREAM-SEDIMENT SAMPLES}

The erosion of mineralized rocks which has added arsenic, gold, copper, and other diagnostic metals to the stream systems that drain the district, has resulted in anomalous concentrations of metals. Many of the anomalies detected in stream sediments and reported in an earlier paper (Hawley and others, 1968) can be correlated with the existence of known deposits, but some anomalies suggest the presence of undiscovered mineralized bodies or very weakly mineralized rocks of wide extent.

Most large areas of anomalous metal concentration were probably found during stream-sediment sampling of the district, but small or subtle anomalies-which may be significant-could have been missed, chiefly because of two factors: the particulate nature of some of the substances sought, and the high limits of analytical detection. Because of the rigorous climate of the district and the recent age of the extensive glaciation, oxidation and leaching of mineralized rocks has not been nearly as important as mechanical disintegration. The anomalous concentrations of metals found, therefore, reflect the presence of discrete particles of metalliferous minerals rather than metals adsorbed on organic or mineral films. The particulate type of metal distribution causes few problems in stream-sediment prospecting for metals that occur in minerals easily broken mechanically; however, it is a major problem in prospecting for elements of refractory minerals, such as gold and tin in cassiterite, where chance mainly determines whether the sample chosen will contain a metalbearing particle.

Because high limits of detection for diagnostic elements of the belt such as arsenic and antimony preclude their detection in many samples, our knowledge of the distribution of these and some other rare elements is incomplete.

\section{BEDROCK BACKGROUND}

A series of 40 samples of apparently unmineralized country rocks was collected and analyzed to aid in interpreting the geochemistry of stream-sediment samples. The number of samples represents, approximately, the abundance of different rock types in the area, with the exception of limestone, which is represented by only one sample. Limestone, because of its characteristic low trace-element content would serve only to lower the regional background deduced from the samples. The results of the chemical analyses are given in table 6 , and data on the most important (economic) elements are summarized as cumulative frequency diagrams in figure 2 . The median concentrations of these elements are compared with the medians of the same elements in stream-sediment samples in table 8 .

Of the five elements for which medians can be read directly or from short projections on the distribution diagram (fig. 2), three-gold, chromium, and nickelare higher than estimated crustal abundance and twocopper and lead-are slightly less. The relatively high abundance of chromium and nickel in the bedrock is mainly accounted for by the red beds (table 6). Copper is relatively abundant in both basalt and gabbro, and three of seven basalt samples contains more copper than do most basalts. Gold probably is more abundant in the bedrock of the region than in most areas, but the limit of detection $(0.02 \mathrm{ppm})$ is so close to the estimated range of the median that no strong significance can be attached to the gold value. The limits of detection for silver, arsenic, and zinc (not shown) are so much higher than their probable abundances that good estimates cannot be made for their median values. In anticipation of the next section, however, it should be pointed out that all the economic elements except gold are more abundant in the average stream-sediment sample of the district than in average bedrock; gold is more abundant in stream-sediment samples of the area than in stream sediment from typical unmineralized terrane.

\section{STREAM-SEDIMENT SAMPLES}

Disregarding replicate samples, about 160 samples of and others, 1960); only selected parts of the data are summarized and discussed here. Figure 3 shows the number of elements present in anomalous concentrastream sediment were collected and analyzed for gold by the atomic absorption method and for gold and 29 these analyses have been presented previously (Hawley other elements by the semiquantitative spectrographic method. The most economically significant results of tions at sample sites in the district. The elements considered in the preparation of figure 3 were gold, silver, copper, lead, zinc, arsenic, and antimony, and the limits of anomalous concentration were estimated in ppm, as:

\begin{tabular}{ccccccc}
$A g$ & $A s$ & $A u$ & $C u$ & $P b$ & $S b$ & $Z n$ \\
\hline 0.5 & If detected & 0.02 & 150 & 30 & If detected & 200
\end{tabular}




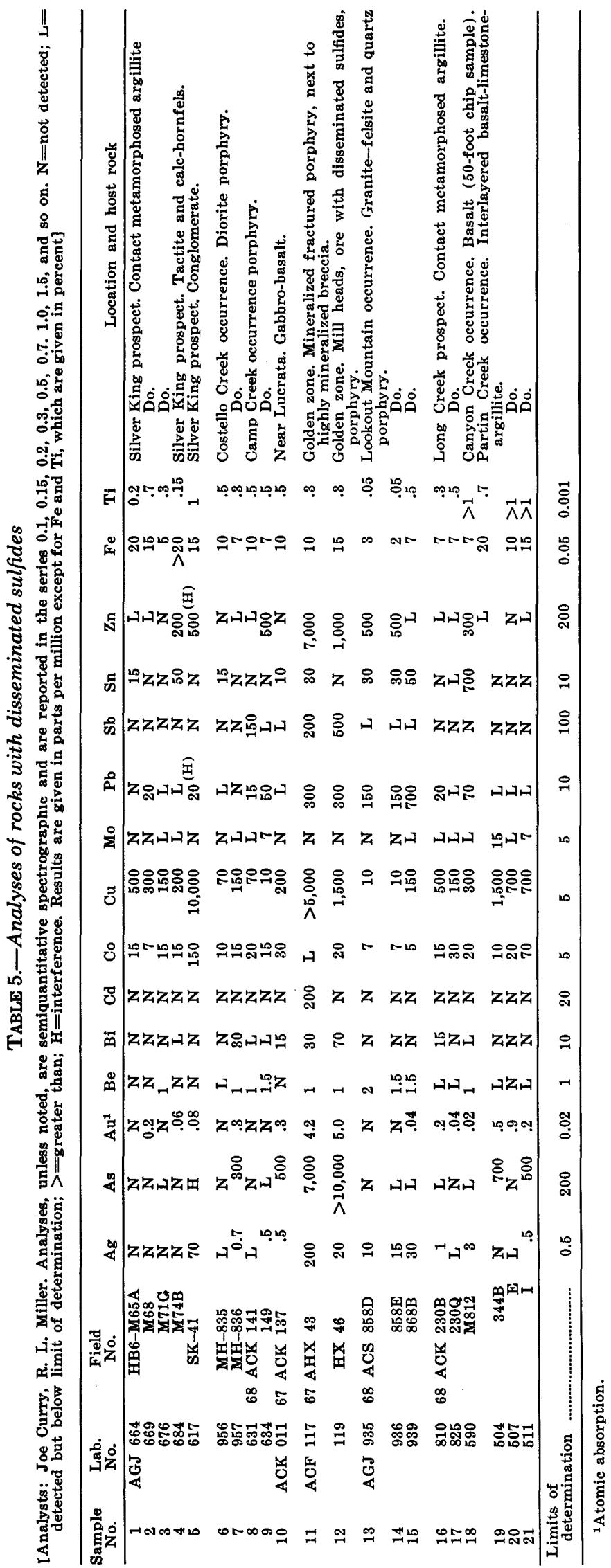

Arsenic and antimony were considered anomalous if present at any concentration because of their relative scarcity in the earth's crust and their high detection limits (As, 200 ppm; Sb, 100 ppm).

The stream-sediment samples seem to have a twofold significance: they help to locate individual metallized deposits, and they appear to correlate with a broad primary metal dispersion pattern throughout a large part of the district. The data suggest that strongly anomalous amounts of gold, silver, arsenic, and lead correlate with well-metallized deposits. For example, all or several of these elements are greatly enriched near the deposits or occurrences at the Golden Zone, Partin Crek, and Canyon Creek.

Silver, zinc, arsenic, and molybdenum in concentrations at or just above the limits of anomalous concentration are not present in significant deposits. Their presence in the northwest, north, and southeast flanks of the northern part of the district may reflect a primary metal dispersion pattern. Lead may have a similar significance.

The results of analyses of eight elements in the group of 160 samples are summarized on frequency-distribution diagrams (figs. 4 and 5). Median concentrations for the same elements are also given in table 8, which gives, for comparison, the median concentration of bedrock samples. Comparison shows that, except for gold, the metals either have a higher median concentration in stream-sediment samples than in country rock, or, where medians cannot be directly calculated, the metals are found in much higher proportion in streamsediment samples than in bedrock samples.

The median concentration of copper is about three times as high in stream-sediments samples than it is in bedrock samples and copper is much more abundant in stream sediments than in rocks of about average crustal composition (table 7). The data are consistent with the interpretation, based on the distribution and copper content of mineralized rocks, that mineralization of the district is partly characterized by copper.

Comparison of the percentage of samples in which gold and arsenic were detected with percentage of detection outside the district suggests those elements are generally enriched, in effect confirming their enrichment in mineralized rocks of the district noted in the preceding section. Gold was detected in more than 20 percent of the stream-sediment samples of the district in concentrations ranging from 0.02 to $0.7 \mathrm{ppm}$. The percentage of detection is higher than in nearby regions in which gold has been determined by the same laboratory on the same type of sample. For example, gold was detected in only 7 percent of the 157 samples from the northern Talkeetna Mountains, approximately 25 miles to the east, and in only about 1.5 percent of more than 
TABLE 6.-Analyses of representative rock types of the Upper Chulitna district

[Analysts: E. L. Mosier, Joe Curry, T. Stein, R. L. Miller. Analyses, unless noted, are semiquantitative spectrographic and are reported in the series 0.1 , $0.15,0.2,0.3,0.5,0.7,1.0,1.5$, and so on. $\mathrm{N}=$ not detected; $\mathrm{L}=$ detected but below limit of determination; ............... $=$ not looked for; $>=\mathrm{greater}$ than Results are given in parts per million except for $\mathrm{Fe}, \mathrm{Mg}, \mathrm{Ca}$, and $\mathrm{Ti}$, which are given in percent]

\begin{tabular}{|c|c|c|c|c|c|c|c|c|c|c|c|c|c|c|c|c|c|c|c|}
\hline $\begin{array}{l}\text { Sample } \\
\text { No. }\end{array}$ & $\begin{array}{l}\text { Lab. } \\
\text { No. }\end{array}$ & $\begin{array}{c}\text { Field } \\
\text { No. }\end{array}$ & $\mathbf{A g}$ & As & $\mathrm{Au}$ & $\mathrm{Au}^{1}$ & $\mathbf{A u}^{2}$ & B & $\mathbf{B a}$ & $\mathbf{B e}$ & $\mathbf{B i}$ & $\mathrm{Cd}$ & Co & $\mathrm{Cr}$ & $\mathrm{Cu}$ & $\mathbf{H g}^{3}$ & $\mathbf{L a}$ & Mo & Mn \\
\hline \multicolumn{20}{|c|}{ Argillite, graywacke, siltstone, hornfels } \\
\hline $\begin{array}{l}1 \\
2 \\
3 \\
4 \\
5\end{array}$ & $\begin{array}{r}\text { AFE 214 } \\
223 \\
219 \\
202 \\
201\end{array}$ & $\begin{array}{rc}67 \mathrm{ACx} & 95 \\
144 \\
147 \mathrm{~A} \\
\mathrm{Hx} 100 \\
56\end{array}$ & $\begin{array}{l}\mathbf{N} \\
\mathbf{N} \\
\mathbf{N} \\
\mathbf{N} \\
\mathbf{N}\end{array}$ & $\begin{array}{l}\mathbf{N} \\
\mathbf{N} \\
\mathbf{N} \\
\mathbf{N} \\
\mathbf{N}\end{array}$ & & $\begin{array}{l}0.03 \\
.02 \\
.02 \\
.02 \\
.02\end{array}$ & & $\begin{array}{l}\mathbf{N} \\
\mathbf{N} \\
\mathbf{N} \\
\mathbf{N} \\
\mathbf{N}\end{array}$ & $\begin{array}{r}300 \\
300 \\
700 \\
50 \\
70\end{array}$ & $\begin{array}{l}\mathbf{N} \\
\mathbf{N} \\
\mathbf{N} \\
\mathbf{N} \\
\mathbf{N}\end{array}$ & $\begin{array}{l}\mathbf{N} \\
\mathbf{N} \\
\mathbf{N} \\
\mathbf{N} \\
\mathbf{N}\end{array}$ & $\begin{array}{l}\mathbf{N} \\
\mathbf{N} \\
\mathbf{N} \\
\mathbf{N} \\
\mathbf{N}\end{array}$ & $\begin{array}{l}10 \\
10 \\
15 \\
7 \\
10\end{array}$ & $\begin{array}{r}150 \\
100 \\
100 \\
20 \\
30\end{array}$ & $\begin{array}{r}50 \\
100 \\
30 \\
30 \\
20\end{array}$ & & $\begin{array}{l}\mathbf{N} \\
\mathbf{N} \\
\mathbf{N} \\
\mathbf{N} \\
\mathbf{N}\end{array}$ & $\begin{array}{l}\mathbf{N} \\
\mathbf{N} \\
\mathbf{N} \\
\mathbf{N} \\
\mathbf{N}\end{array}$ & $\begin{array}{r}1,000 \\
700 \\
1,000 \\
700 \\
700\end{array}$ \\
\hline $\begin{array}{r}7 \\
8 \\
9 \\
10 \\
11 \\
\end{array}$ & $\begin{array}{r}218 \\
220 \\
216 \\
222 \\
\text { AGJ } 859 \\
\end{array}$ & $\begin{array}{c}\mathrm{Cx} 137 \\
150 \\
120 \\
174 \\
56-\mathrm{H} 34 \mathrm{~B} \\
\end{array}$ & $\begin{array}{l}\mathbf{N} \\
\mathbf{N} \\
\mathbf{N} \\
\mathbf{N} \\
\mathbf{N} \\
\end{array}$ & $\begin{array}{l}\mathbf{N} \\
\mathbf{N} \\
\mathbf{N} \\
\mathbf{N} \\
\mathbf{N} \\
\end{array}$ & & $\begin{array}{l}.02 \\
.03 \\
.03 \\
.02 \\
.02 \\
\end{array}$ & & $\begin{array}{l}\mathbf{N} \\
\mathbf{N} \\
\mathbf{N} \\
\mathbf{N} \\
\mathbf{3 0} \\
\end{array}$ & $\begin{array}{r}200 \\
10 \\
1,000 \\
300 \\
1,500 \\
\end{array}$ & $\begin{array}{l}\mathbf{N} \\
\mathbf{N} \\
\mathbf{N} \\
\mathbf{N} \\
\mathbf{1} \\
\end{array}$ & $\begin{array}{l}\mathbf{N} \\
\mathbf{N} \\
\mathbf{N} \\
\mathbf{N} \\
\mathbf{N} \\
\end{array}$ & $\begin{array}{l}\mathbf{N} \\
\mathbf{N} \\
\mathbf{N} \\
\mathbf{N} \\
\mathbf{N} \\
\end{array}$ & $\begin{array}{l}30 \\
10 \\
10 \\
10 \\
15 \\
\end{array}$ & $\begin{array}{r}150 \\
50 \\
10 \\
5 \\
150 \\
\end{array}$ & $\begin{array}{l}50 \\
20 \\
30 \\
30 \\
70 \\
\end{array}$ & & $\begin{array}{l}\mathbf{N} \\
\mathbf{N} \\
\mathbf{N} \\
\mathbf{N} \\
\mathbf{L} \\
\end{array}$ & $\begin{array}{l}\mathbf{N} \\
\mathbf{N} \\
\mathbf{N} \\
\mathbf{7} \\
\mathbf{}\end{array}$ & $\begin{array}{r}1,000 \\
2,000 \\
3,000 \\
2,000 \\
500 \\
\end{array}$ \\
\hline \multicolumn{20}{|c|}{ Red siltstone and conglomerate } \\
\hline $\begin{array}{l}12 \\
13 \\
14 \\
15 \\
16\end{array}$ & $\begin{array}{r}\text { AFE 210 } \\
211 \\
204 \\
205 \\
206\end{array}$ & $\begin{array}{cc}67 \mathrm{ACx} & 65 \mathrm{~A} \\
66 \\
\mathrm{Hx} 221 \\
213 \\
219 \mathrm{~A}\end{array}$ & $\begin{array}{l}\mathbf{N} \\
\mathbf{N} \\
\mathbf{N} \\
\mathbf{N} \\
\mathbf{N}\end{array}$ & $\begin{array}{l}\mathbf{N} \\
\mathbf{N} \\
\mathbf{N} \\
\mathbf{N} \\
\mathbf{N}\end{array}$ & & $\begin{array}{r}0.02 \\
.02 \\
.02 \\
.03 \\
.02\end{array}$ & & $\begin{array}{l}\mathbf{N} \\
\mathbf{N} \\
\mathbf{N} \\
\mathbf{N} \\
\mathbf{N}\end{array}$ & $\begin{array}{r}150 \\
100 \\
100 \\
200 \\
70\end{array}$ & $\begin{array}{l}\mathbf{N} \\
\mathbf{N} \\
\mathbf{N} \\
\mathbf{N} \\
\mathbf{N}\end{array}$ & $\begin{array}{l}\mathbf{N} \\
\mathbf{N} \\
\mathbf{N} \\
\mathbf{N} \\
\mathbf{N}\end{array}$ & $\begin{array}{l}\mathbf{N} \\
\mathbf{N} \\
\mathbf{N} \\
\mathbf{N} \\
\mathbf{N}\end{array}$ & $\begin{array}{l}20 \\
10 \\
20 \\
20 \\
10\end{array}$ & $\begin{array}{r}200 \\
50 \\
200 \\
200 \\
150\end{array}$ & $\begin{array}{r}50 \\
70 \\
5 \\
20 \\
5\end{array}$ & & $\begin{array}{l}\mathbf{N} \\
\mathbf{N} \\
\mathbf{N} \\
\mathbf{N} \\
\mathbf{N}\end{array}$ & $\begin{array}{l}\mathbf{N} \\
\mathbf{N} \\
\mathbf{N} \\
\mathbf{N} \\
\mathbf{N}\end{array}$ & $\begin{array}{r}1,000 \\
1,000 \\
700 \\
1,000 \\
1,500\end{array}$ \\
\hline $\begin{array}{l}17 \\
18 \\
19 \\
20 \\
\end{array}$ & $\begin{array}{l}\text { ACF } 102 \\
\text { ACE } 613 \\
\text { ACF } 057 \\
\text { AGJ } 860 \\
\end{array}$ & 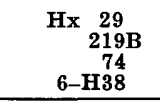 & $\begin{array}{l}\mathbf{N} \\
\mathbf{L} \\
\mathbf{N} \\
\mathbf{N} \\
\end{array}$ & $\begin{array}{l}\mathbf{N} \\
\mathbf{N} \\
\mathbf{N} \\
\mathbf{L}\end{array}$ & & $\begin{array}{l}\mathrm{N} \\
\mathrm{N} \\
\mathrm{N} \\
.02 \\
\end{array}$ & & $\begin{array}{l}10 \\
15 \\
20 \\
10 \\
\end{array}$ & $\begin{array}{r}150 \\
300 \\
>5,000 \\
300 \\
\end{array}$ & $\begin{array}{l}\mathbf{N} \\
\mathbf{L} \\
\mathbf{N} \\
\mathbf{L}\end{array}$ & $\begin{array}{l}\mathbf{N} \\
\mathbf{N} \\
\mathbf{N} \\
\mathbf{N}\end{array}$ & $\begin{array}{l}\mathbf{N} \\
\mathbf{N} \\
\mathbf{N} \\
\mathbf{N} \\
\end{array}$ & $\begin{array}{l}15 \\
70 \\
30 \\
20 \\
\end{array}$ & $\begin{array}{r}500 \\
1,000 \\
1,000 \\
300 \\
\end{array}$ & $\begin{array}{l}30 \\
20 \\
20 \\
70 \\
\end{array}$ & 0.09 & $\begin{array}{l}\mathbf{N} \\
\mathbf{L} \\
\mathbf{L} \\
\mathbf{L} \\
\end{array}$ & $\begin{array}{l}N \\
N \\
5 \\
5 \\
\end{array}$ & $\begin{array}{r}>5,000 \\
1,500 \\
150 \\
700 \\
\end{array}$ \\
\hline \multicolumn{20}{|c|}{ Limestone } \\
\hline 21 & AFE 224 & $67 \mathrm{ACx} 308$ & $\mathbf{N}$ & $\mathbf{N}$ & & 0.04 & & $\mathbf{N}$ & 50 & $\mathbf{N}$ & $\mathbf{N}$ & $\mathbf{N}$ & 5 & 5 & $\mathrm{~L}$ & - & $\mathbf{N}$ & $\mathbf{N}$ & 1,000 \\
\hline \multicolumn{20}{|c|}{ Basalt and gabbro (includes greenstone) } \\
\hline $\begin{array}{l}22 \\
23 \\
24 \\
25 \\
26\end{array}$ & $\begin{array}{r}\text { AFE } 208 \\
215 \\
221 \\
\text { ACF } 007 \\
009\end{array}$ & $\begin{array}{rr}67 \mathrm{ACx} & 52 \\
114 \\
163 \\
\mathrm{Hx} 113 \\
121\end{array}$ & $\begin{array}{l}\mathrm{N} \\
\mathrm{N} \\
\mathrm{N} \\
0.5 \\
\mathrm{~N}\end{array}$ & $\begin{array}{l}\mathbf{N} \\
\mathbf{N} \\
\mathbf{N} \\
\mathbf{N} \\
\mathbf{N}\end{array}$ & $\begin{array}{l}\mathbf{N} \\
\mathbf{N} \\
\mathbf{N} \\
\mathbf{N} \\
\mathbf{N}\end{array}$ & $\begin{array}{l}0.04 \\
\mathrm{~N} \\
.13 \\
.04 \\
.04\end{array}$ & $\overline{-}$ & $\begin{array}{l}\mathbf{N} \\
\mathbf{N} \\
\mathbf{N} \\
\mathbf{L} \\
20\end{array}$ & $\begin{array}{r}700 \\
300 \\
300 \\
70 \\
500\end{array}$ & $\begin{array}{l}\mathbf{N} \\
\mathbf{N} \\
\mathbf{N} \\
\mathbf{N} \\
\mathbf{L}\end{array}$ & $\begin{array}{l}\mathbf{N} \\
\mathbf{N} \\
\mathbf{N} \\
\mathbf{N}\end{array}$ & $\begin{array}{l}\mathbf{N} \\
\mathbf{N} \\
\mathbf{N} \\
\mathbf{N} \\
\mathbf{N}\end{array}$ & $\begin{array}{l}20 \\
10 \\
20 \\
50 \\
50\end{array}$ & $\begin{array}{l}100 \\
30 \\
200 \\
300 \\
100\end{array}$ & $\begin{array}{r}50 \\
15 \\
20 \\
100 \\
500\end{array}$ & - & $\begin{array}{l}\mathbf{N} \\
\mathbf{N} \\
\mathbf{N} \\
\mathbf{N} \\
\mathbf{N}\end{array}$ & $\begin{array}{l}\mathbf{N} \\
\mathbf{N} \\
\mathbf{N} \\
\mathbf{N}\end{array}$ & $\begin{array}{r}700 \\
700 \\
700 \\
700 \\
1,000\end{array}$ \\
\hline $\begin{array}{l}27 \\
28 \\
\end{array}$ & $\begin{array}{r}\text { AGJ } 854 \\
\quad 852 \\
\end{array}$ & $\begin{array}{r}56-\mathrm{H} 18 \\
\mathrm{H} 2 \mathrm{~B} \\
\end{array}$ & $\mathbf{N}$ & $\begin{array}{l}\mathbf{N} \\
\mathbf{N} \\
\end{array}$ & $\begin{array}{l}\mathbf{N} \\
\mathbf{N} \\
\end{array}$ & $\begin{array}{l}.02 \\
.04 \\
\end{array}$ & & $\begin{array}{l}10 \\
10 \\
\end{array}$ & $\begin{array}{l}300 \\
500 \\
\end{array}$ & $\begin{array}{l}\mathbf{N} \\
\mathbf{L}\end{array}$ & $\stackrel{\mathbf{N}}{\mathbf{N}}$ & $\begin{array}{l}\mathbf{N} \\
\mathbf{N} \\
\end{array}$ & $\begin{array}{l}\mathbf{5 0} \\
\mathbf{5 0} \\
\end{array}$ & $\begin{array}{r}70 \\
100 \\
\end{array}$ & $\begin{array}{l}300 \\
300 \\
\end{array}$ & & $\begin{array}{l}\mathbf{L} \\
\mathbf{L}\end{array}$ & $\begin{array}{l}5 \\
5 \\
\end{array}$ & $\begin{array}{l}1,000 \\
1,500 \\
\end{array}$ \\
\hline \multicolumn{20}{|c|}{ Tuff } \\
\hline $\begin{array}{l}29 \\
30 \\
\end{array}$ & $\begin{array}{r}\text { AFE } 209 \\
207 \\
\end{array}$ & $\begin{array}{cc}67 \mathrm{ACx} & 58 \\
& 29 \mathrm{~A} \\
\end{array}$ & $\mathbf{N}$ & $\begin{array}{l}\mathbf{N} \\
\mathbf{N}\end{array}$ & $\mathbf{N}$ & $\begin{array}{r}0.04 \\
.04 \\
\end{array}$ & - & $\mathbf{N}$ & $\begin{array}{l}300 \\
500 \\
\end{array}$ & $\mathbf{N}$ & $\mathbf{N}$ & $\mathbf{N}$ & $\begin{array}{l}10 \\
15 \\
\end{array}$ & $\begin{array}{r}5 \\
100 \\
\end{array}$ & $\begin{array}{l}10 \\
20 \\
\end{array}$ & & $\begin{array}{l}\mathbf{N} \\
\mathbf{N} \\
\end{array}$ & $\mathbf{N}$ & $\begin{array}{r}1,500 \\
700 \\
\end{array}$ \\
\hline \multicolumn{20}{|c|}{ Intermediate igneous rocks (quartz diorite) } \\
\hline $\begin{array}{l}31 \\
32 \\
33 \\
34 \\
35\end{array}$ & $\begin{array}{r}\text { AFE 212 } \\
213 \\
203 \\
217 \\
\text { ACE } 616\end{array}$ & $\begin{array}{rr}67 \mathrm{ACx} \quad 85 \\
89 \\
124 \\
133 \\
67 \mathrm{AHx} 229\end{array}$ & $\begin{array}{l}\mathbf{N} \\
\mathbf{N} \\
\mathbf{N} \\
\mathbf{N} \\
\mathbf{N}\end{array}$ & $\begin{array}{l}\mathbf{N} \\
\mathbf{N} \\
\mathbf{N} \\
\mathbf{N} \\
\mathbf{N}\end{array}$ & $\begin{array}{l}\mathbf{N} \\
\mathbf{N} \\
\mathbf{N} \\
\mathbf{N} \\
\mathbf{N}\end{array}$ & $\begin{array}{c}\mathrm{N} \\
0.02 \\
.02 \\
.02 \\
.02\end{array}$ & - & $\begin{array}{l}\mathbf{N} \\
\mathbf{N} \\
\mathbf{N} \\
\mathbf{N} \\
\mathbf{1 0}\end{array}$ & $\begin{array}{l}1,000 \\
1,000 \\
300 \\
1,000 \\
1,500\end{array}$ & $\begin{array}{l}\mathbf{N} \\
\mathbf{N} \\
\mathbf{N} \\
\mathbf{L} \\
\mathbf{N}\end{array}$ & $\begin{array}{l}\mathbf{N} \\
\mathbf{N} \\
\mathbf{N} \\
\mathbf{N} \\
\mathbf{N}\end{array}$ & $\begin{array}{l}\mathbf{N} \\
\mathbf{N} \\
\mathbf{N} \\
\mathbf{N} \\
\mathbf{N}\end{array}$ & $\begin{array}{c}10 \\
15 \\
10 \\
5 \\
10\end{array}$ & $\begin{array}{l}50 \\
30 \\
10 \\
70 \\
70\end{array}$ & $\begin{array}{l}10 \\
30 \\
10 \\
20 \\
20\end{array}$ & & $\begin{array}{l}20 \\
20 \\
\mathbf{N} \\
30 \\
\mathrm{~N}\end{array}$ & $\begin{array}{l}\mathbf{N} \\
\mathbf{N} \\
\mathbf{N} \\
\mathbf{N} \\
5\end{array}$ & $\begin{array}{r}2,000 \\
2,000 \\
1,000 \\
700 \\
1,000\end{array}$ \\
\hline $\begin{array}{l}36 \\
37 \\
38 \\
\end{array}$ & $\begin{array}{r}\text { ACF } 002 \\
003 \\
006 \\
\end{array}$ & $\begin{array}{l}103 \\
107 \\
118 \\
\end{array}$ & $\begin{array}{l}N \\
L \\
L\end{array}$ & $\begin{array}{l}\mathbf{N} \\
\mathbf{N} \\
\mathbf{N}\end{array}$ & $\begin{array}{l}\mathbf{N} \\
\mathbf{N} \\
\mathbf{N} \\
\end{array}$ & $\begin{array}{l}\mathbf{N} \\
\mathbf{N} \\
.04 \\
\end{array}$ & & $\begin{array}{l}20 \\
15 \\
10 \\
\end{array}$ & $\begin{array}{r}300 \\
700 \\
1,500 \\
\end{array}$ & $\begin{array}{l}\mathbf{L} \\
\mathbf{L} \\
\mathbf{1}\end{array}$ & $\begin{array}{l}\mathbf{N} \\
\mathbf{N} \\
\mathbf{N}\end{array}$ & $\begin{array}{l}\mathbf{N} \\
\mathbf{N} \\
\mathbf{N}\end{array}$ & $\begin{array}{l}30 \\
30 \\
20 \\
\end{array}$ & $\begin{array}{l}300 \\
200 \\
300 \\
\end{array}$ & $\begin{array}{l}30 \\
15 \\
30 \\
\end{array}$ & & $\begin{array}{l}30 \\
30 \\
30\end{array}$ & $\begin{array}{l}\mathbf{N} \\
\mathbf{N} \\
\mathbf{N} \\
\end{array}$ & $\begin{array}{r}700 \\
1,000 \\
700 \\
\end{array}$ \\
\hline \multicolumn{20}{|c|}{ Granite rocks (quartz porphyry, felsite, aplite) } \\
\hline $\begin{array}{l}39 \\
40 \\
41 \\
\end{array}$ & $\begin{array}{l}\text { ACF } 058 \\
\text { AGJ } 858 \\
\end{array}$ & $\begin{array}{r}67 \mathrm{AHx} 135 \mathrm{~B} \\
169 \\
56-\mathrm{H} 34 \mathrm{~A} \\
\end{array}$ & $\begin{array}{l}0.7 \\
\dot{N}^{7} \\
\end{array}$ & $\begin{array}{l}\mathrm{L} \\
\mathrm{N} \\
\mathrm{L}\end{array}$ & $\begin{array}{l}\mathbf{N} \\
\mathbf{N} \\
\mathbf{N} \\
\end{array}$ & $\begin{array}{c}\mathbf{N} \\
\mathrm{N} \\
0.04\end{array}$ & $\begin{array}{l}\mathbf{N} \\
\mathbf{N} \\
\mathbf{N}\end{array}$ & $\begin{array}{l}15 \\
\mathbf{L} \\
50\end{array}$ & $\begin{array}{r}700 \\
1,000 \\
700 \\
\end{array}$ & $\begin{array}{c}1.5 \\
1 \\
2 \\
\end{array}$ & $\begin{array}{l}\mathbf{N} \\
\mathbf{N} \\
\mathbf{N}\end{array}$ & $\begin{array}{l}\mathbf{N} \\
\mathbf{N} \\
\mathbf{N}\end{array}$ & $\begin{array}{l}7 \\
5 \\
\text { N } \\
\end{array}$ & $\begin{array}{l}15 \\
\mathrm{~L} \\
\mathrm{~L} \\
\end{array}$ & $\begin{array}{r}55 \\
50 \\
7 \\
\end{array}$ & - & $\begin{array}{l}20 \\
\mathrm{~N} \\
\end{array}$ & $\begin{array}{l}\mathrm{L} \\
\mathrm{N} \\
\mathrm{N}\end{array}$ & $\begin{array}{l}700 \\
200 \\
150 \\
\end{array}$ \\
\hline dete & ination & & 0.5 & 200 & 10 & 0.02 & 0.05 & 10 & 5 & 1 & 10 & 20 & 5 & 5 & 5 & 0.01 & 20 & 5 & 10 \\
\hline
\end{tabular}

See footnotes at end of table.

1,100 samples from the southern Alaska Range about 125 miles southwest (Reed and Elliott, 1968a, b, c,; Elliott and Reed, 1968). These areas are the closest ones to the district for which analyses are available. The northern Talkeetna Mountains are not known to be strongly mineralized; the southern Alaska Range area is known to be but is in a province characterized principally by silver, lead, and zinc rather than arsenic and gold.

A general enrichment in gold is suggested by its estimated median concentration of 0.001-0.005 ppm. This concentration is approximately the same as the crustal abundance of gold, but Fischer and Fisher
(1968, p. 2) have estimated that the gold in streams draining nonauriferous regions may be within the range $0.000 \mathrm{X}$ to $0.0000 \mathrm{X} \mathrm{ppm}$ or "probably one or two orders less than the crustal abundance."

In summary, the geochemistry of stream-sediment samples from the district not only indicates the location of metalliferous deposits within a drainage but also suggests a wide primary dispersion of elements, including silver, zinc, and arsenic. The evidence also suggests that the district is a mineralized region characterized by gold, arsenic, copper, and a few other metals.

\section{ZONING}

Geologic knowledge of the district is not yet at a 
TABLE 6.-Analyses of representative rock types of the Upper Chulitna district-Continued

\begin{tabular}{|c|c|c|c|c|c|c|c|c|c|c|c|c|c|c|c|c|c|c|}
\hline $\begin{array}{c}\text { Sample } \\
\text { No. }\end{array}$ & $\begin{array}{l}\text { Lab. } \\
\text { No. }\end{array}$ & $\begin{array}{c}\text { Field } \\
\text { No. }\end{array}$ & $\mathrm{Nb}$ & $\mathrm{Ni}$ & $\mathbf{P b}$ & $\mathbf{S b}$ & Sc & Sn & $\mathbf{S r}$ & $\mathbf{v}$ & $\mathbf{w}$ & $\mathbf{Y}$ & $\mathbf{Z n}$ & $\mathbf{Z r}$ & $\mathbf{F e}$ & $\mathbf{M g}$ & $\mathbf{C a}$ & $\mathbf{T i}$ \\
\hline \multicolumn{19}{|c|}{ Argillite, graywacke, siltstone, hornfels } \\
\hline $\begin{array}{l}1 \\
2 \\
3 \\
4 \\
5\end{array}$ & $\begin{array}{r}\text { AFE } 214 \\
223 \\
219 \\
202 \\
201\end{array}$ & $\begin{array}{rc}67 \mathrm{ACx} & 95 \\
144 \\
147 \mathrm{~A} \\
\mathrm{Hx} 100 \\
56\end{array}$ & $\begin{array}{l}10 \\
\mathbf{L} \\
10 \\
\mathbf{N} \\
\mathrm{L}\end{array}$ & $\begin{array}{r}50 \\
70 \\
70 \\
5 \\
10\end{array}$ & $\begin{array}{l}N \\
10 \\
10 \\
L \\
L\end{array}$ & $\begin{array}{l}\mathbf{N} \\
\mathbf{N} \\
\mathbf{N} \\
\mathbf{N} \\
\mathbf{N}\end{array}$ & $\begin{array}{l}20 \\
10 \\
15 \\
10 \\
10\end{array}$ & $\begin{array}{l}\mathbf{N} \\
\mathbf{N} \\
\mathbf{N} \\
\mathbf{N} \\
\mathbf{N}\end{array}$ & $\begin{array}{l}500 \\
100 \\
200 \\
100 \\
100\end{array}$ & $\begin{array}{r}300 \\
100 \\
200 \\
100 \\
70\end{array}$ & $\begin{array}{l}\mathbf{N} \\
\mathbf{N} \\
\mathbf{N} \\
\mathbf{N} \\
\mathbf{N}\end{array}$ & $\begin{array}{l}20 \\
15 \\
20 \\
15 \\
10\end{array}$ & $\begin{array}{l}\mathbf{N} \\
\mathbf{N} \\
\mathbf{N} \\
\mathbf{N} \\
\mathbf{N}\end{array}$ & $\begin{array}{r}100 \\
100 \\
200 \\
70 \\
50\end{array}$ & $\begin{array}{l}\mathbf{5} \\
\mathbf{3} \\
\mathbf{3} \\
\mathbf{2} \\
\mathbf{2}\end{array}$ & $\begin{array}{r}0.7 \\
.7 \\
.7 \\
1.7\end{array}$ & $\begin{array}{l}2 \\
1 \\
1.5 \\
5 \\
7\end{array}$ & $\begin{array}{l}1 \\
.3 \\
.5 \\
.5 \\
.3\end{array}$ \\
\hline $\begin{array}{r}7 \\
8 \\
9 \\
10 \\
11 \\
\end{array}$ & $\begin{array}{r}218 \\
220 \\
216 \\
222 \\
\text { AGJ } 859 \\
\end{array}$ & $\begin{array}{r}\text { Cx } 137 \\
150 \\
120 \\
174 \\
56-\mathbf{H 4 B} \\
\end{array}$ & $\begin{array}{l}\mathbf{N} \\
\mathbf{N} \\
\mathbf{L} \\
\mathbf{N} \\
\mathbf{1 0} \\
\end{array}$ & $\begin{array}{r}100 \\
20 \\
10 \\
5 \\
100 \\
\end{array}$ & $\begin{array}{l}\mathbf{N} \\
\mathrm{L} \\
\mathbf{1 0} \\
\mathbf{L} \\
\mathbf{2 0} \\
\end{array}$ & $\begin{array}{l}\mathbf{N} \\
\mathbf{N} \\
\mathbf{N} \\
\mathbf{N} \\
\mathbf{N} \\
\end{array}$ & $\begin{array}{l}20 \\
15 \\
10 \\
20 \\
15 \\
\end{array}$ & $\begin{array}{l}\mathbf{N} \\
\mathbf{N} \\
\mathbf{N} \\
\mathbf{N} \\
\mathbf{N}\end{array}$ & $\begin{array}{l}200 \\
150 \\
150 \\
500 \\
100 \\
\end{array}$ & $\begin{array}{l}200 \\
150 \\
150 \\
150 \\
150 \\
\end{array}$ & $\begin{array}{l}\mathbf{N} \\
\mathbf{N} \\
\mathbf{N} \\
\mathbf{N} \\
\mathbf{N}\end{array}$ & $\begin{array}{l}20 \\
15 \\
10 \\
20 \\
15 \\
\end{array}$ & $\begin{array}{r}\mathbf{N} \\
\mathbf{N} \\
\mathbf{N} \\
\mathbf{N} \\
\mathbf{2 0 0}\end{array}$ & $\begin{array}{l}50 \\
70 \\
50 \\
70 \\
70 \\
\end{array}$ & $\begin{array}{l}\mathbf{3} \\
\mathbf{3} \\
\mathbf{3} \\
\mathbf{3} \\
\mathbf{3} \\
\mathbf{3} \\
\end{array}$ & $\begin{array}{r}1.5 \\
.7 \\
.7 \\
.7 \\
1.5 \\
\end{array}$ & $\begin{array}{l}5 \\
7 \\
2.15 \\
.3 \\
\end{array}$ & $\begin{array}{l}.5 \\
.3 \\
.3 \\
.3 \\
.7 \\
\end{array}$ \\
\hline \multicolumn{19}{|c|}{ Red siltstone and conglomerate } \\
\hline $\begin{array}{l}12 \\
13 \\
14 \\
15 \\
16\end{array}$ & $\begin{array}{r}\text { AFE } 210 \\
211 \\
204 \\
205 \\
206\end{array}$ & $\begin{array}{c}67 \mathrm{ACx} \\
65 \mathrm{~A} \\
\mathrm{Hx} \\
221 \\
213 \\
219 \mathrm{~A}\end{array}$ & $\begin{array}{l}\mathbf{L} \\
\mathbf{L} \\
\mathbf{L} \\
\mathbf{L} \\
\mathbf{N}\end{array}$ & $\begin{array}{r}150 \\
70 \\
150 \\
150 \\
200\end{array}$ & $\begin{array}{l}\mathbf{N} \\
\mathbf{N} \\
\mathbf{N} \\
\mathbf{N} \\
\mathbf{N}\end{array}$ & $\begin{array}{l}\mathbf{N} \\
\mathbf{N} \\
\mathbf{N} \\
\mathbf{N} \\
\mathbf{N}\end{array}$ & $\begin{array}{r}20 \\
7 \\
20 \\
20 \\
10\end{array}$ & $\begin{array}{l}\mathbf{N} \\
\mathbf{N} \\
\mathbf{N} \\
\mathbf{N} \\
\mathbf{N}\end{array}$ & $\begin{array}{l}100 \\
300 \\
100 \\
700 \\
100\end{array}$ & $\begin{array}{r}200 \\
200 \\
100 \\
70 \\
70\end{array}$ & $\begin{array}{l}\mathbf{N} \\
\mathbf{N} \\
\mathbf{N} \\
\mathbf{N} \\
\mathbf{N}\end{array}$ & $\begin{array}{l}10 \\
15 \\
15 \\
20 \\
10\end{array}$ & $\begin{array}{l}\mathbf{N} \\
\mathbf{N} \\
\mathbf{N} \\
\mathbf{N} \\
\mathbf{N}\end{array}$ & $\begin{array}{l}50 \\
10 \\
70 \\
50 \\
10\end{array}$ & $\begin{array}{l}\mathbf{3} \\
\mathbf{3} \\
\mathbf{5} \\
\mathbf{5} \\
\mathbf{3}\end{array}$ & $\begin{array}{l}1.5 \\
1 \\
1.5 \\
1.5 \\
1.5\end{array}$ & $\begin{array}{l}7 \\
7 \\
1 \\
7 \\
7\end{array}$ & $\begin{array}{r}0.5 \\
.1 \\
.7 \\
.3 \\
.2\end{array}$ \\
\hline $\begin{array}{l}17 \\
18 \\
19 \\
20 \\
\end{array}$ & $\begin{array}{l}\text { ACF 102 } \\
\text { ACE } 613 \\
\text { ACF } 057 \\
\text { AGJ } 860 \\
\end{array}$ & $\begin{array}{c}\mathrm{Hx} \quad 29 \\
219 \mathrm{~B} \\
74 \\
6-\mathrm{H} 38 \\
\end{array}$ & $\begin{array}{l}\mathbf{N} \\
\mathbf{3 0} \\
\mathbf{N} \\
\mathbf{1 0} \\
\end{array}$ & $\begin{array}{r}15 \\
500 \\
150 \\
100 \\
\end{array}$ & $\begin{array}{l}\mathbf{3 0} \\
\mathbf{3 0} \\
\mathbf{N} \\
\mathbf{L} \\
\end{array}$ & $\begin{array}{l}\mathbf{N} \\
\mathbf{N} \\
\mathbf{N} \\
\mathbf{N}\end{array}$ & $\begin{array}{l}30 \\
20 \\
20 \\
20 \\
\end{array}$ & $\begin{array}{l}\mathbf{N} \\
\mathbf{N} \\
\mathbf{N} \\
\mathbf{N}\end{array}$ & $\begin{array}{l}\mathbf{1 5 0} \\
\mathbf{2 0 0} \\
\mathbf{N} \\
150 \\
\end{array}$ & $\begin{array}{r}\mathbf{1 5 0} \\
70 \\
1,500 \\
\mathbf{3 0 0} \\
\end{array}$ & $\begin{array}{l}\mathbf{N} \\
\mathbf{N} \\
\mathbf{N} \\
\mathbf{N}\end{array}$ & $\begin{array}{l}15 \\
15 \\
20 \\
15 \\
\end{array}$ & $\begin{array}{l}\mathbf{N} \\
\mathbf{N} \\
\mathbf{N} \\
\mathbf{L} \\
\end{array}$ & $\begin{array}{r}30 \\
15 \\
100 \\
70 \\
\end{array}$ & $\begin{array}{l}\mathbf{3} \\
\mathbf{7} \\
\mathbf{2} \\
\mathbf{5} \\
\end{array}$ & $\begin{array}{r}7 \\
10 \\
1 \\
3 \\
\end{array}$ & $2^{20}{ }^{.5}$ & $\begin{array}{l}.15 \\
.3 \\
.2 \\
.7 \\
\end{array}$ \\
\hline \multicolumn{19}{|c|}{ Limestone } \\
\hline 21 & AFE 224 & $67 \mathrm{ACx} 308$ & $\mathbf{N}$ & $\mathbf{N}$ & $\mathbf{N}$ & $\mathbf{N}$ & 10 & $\mathbf{N}$ & 300 & $\mathbf{L}$ & $\mathbf{N}$ & 20 & $\mathbf{N}$ & 10 & 0.2 & 0.3 & 720 & 0.01 \\
\hline \multicolumn{19}{|c|}{ Basalt and gabbro (includes greenstone) } \\
\hline $\begin{array}{l}22 \\
23 \\
24 \\
25 \\
26\end{array}$ & $\begin{array}{r}\text { AFE 208 } \\
215 \\
221 \\
\text { ACF } 007 \\
009\end{array}$ & $\begin{array}{rr}67 \mathrm{ACx} & 52 \\
114 \\
163 \\
\mathrm{Hx} 113 \\
121\end{array}$ & $\begin{array}{l}\mathbf{N} \\
\mathbf{N} \\
\mathbf{N} \\
\mathbf{N} \\
\mathbf{N}\end{array}$ & $\begin{array}{r}50 \\
5 \\
100 \\
70 \\
50\end{array}$ & $\begin{array}{r}\mathbf{N} \\
\mathbf{N} \\
\mathbf{N} \\
100 \\
20\end{array}$ & $\begin{array}{l}\mathbf{N} \\
\mathbf{N} \\
\mathbf{N} \\
\mathbf{N} \\
\mathbf{N}\end{array}$ & $\begin{array}{l}20 \\
20 \\
20 \\
30 \\
30\end{array}$ & $\begin{array}{l}\mathbf{N} \\
\mathbf{N} \\
\mathbf{N} \\
\mathbf{N} \\
\mathbf{N}\end{array}$ & $\begin{array}{l}\mathbf{3 0 0} \\
\mathbf{3 0 0} \\
\mathbf{3 0 0} \\
\mathbf{2 0 0} \\
\mathbf{5 0 0}\end{array}$ & $\begin{array}{l}200 \\
200 \\
200 \\
100 \\
200\end{array}$ & $\begin{array}{l}\mathbf{N} \\
\mathbf{N} \\
\mathbf{N} \\
\mathbf{N} \\
\mathbf{N}\end{array}$ & $\begin{array}{l}15 \\
15 \\
15 \\
15 \\
30\end{array}$ & $\begin{array}{l}\mathbf{N} \\
\mathbf{N} \\
\mathbf{N} \\
\mathbf{N} \\
\mathbf{L}\end{array}$ & $\begin{array}{r}20 \\
20 \\
20 \\
30 \\
150\end{array}$ & $\begin{array}{l}\mathbf{3} \\
\mathbf{3} \\
\mathbf{3} \\
\mathbf{5} \\
\mathbf{7}\end{array}$ & $\begin{array}{l}\mathbf{2} \\
1 \\
2 \\
\mathbf{3} \\
\mathbf{2}\end{array}$ & $\begin{array}{l}1 \\
3 \\
3 \\
1.5 \\
1\end{array}$ & $\begin{array}{l}0.3 \\
.05 \\
.3 \\
.^{.03}\end{array}$ \\
\hline $\begin{array}{l}27 \\
28 \\
\end{array}$ & $\begin{array}{r}\text { AGJ } 854 \\
852 \\
\end{array}$ & $\begin{array}{r}56-\mathrm{H} 18 \\
\mathrm{H} 2 \mathrm{~B} \\
\end{array}$ & $\begin{array}{l}10 \\
15 \\
\end{array}$ & $\begin{array}{r}70 \\
100 \\
\end{array}$ & $\stackrel{\mathbf{N}}{\mathbf{N}}$ & $\mathbf{N}$ & $\begin{array}{l}\mathbf{1 5} \\
\mathbf{3 0} \\
\end{array}$ & $\stackrel{\mathbf{N}}{\mathbf{N}}$ & $\begin{array}{l}150 \\
700 \\
\end{array}$ & $\begin{array}{l}150 \\
300 \\
\end{array}$ & $\mathbf{N}$ & $\begin{array}{l}\mathbf{3 0} \\
\mathbf{3 0} \\
\end{array}$ & $\begin{array}{c}\mathbf{L} \\
\mathbf{2 0 0} \\
\end{array}$ & $\begin{array}{l}100 \\
300 \\
\end{array}$ & $\begin{array}{l}10 \\
10 \\
\end{array}$ & $\begin{array}{l}\mathbf{9} \\
\mathbf{2} \\
\end{array}$ & $\begin{array}{l}\mathbf{5} \\
\mathbf{3} \\
\end{array}$ & $\begin{array}{l}>1 \\
>1\end{array}$ \\
\hline \multicolumn{19}{|c|}{ Tuff } \\
\hline $\begin{array}{l}29 \\
30 \\
\end{array}$ & $\begin{array}{r}\text { AFE 209 } \\
207 \\
\end{array}$ & $\begin{array}{rl}67 \mathrm{ACx} & 58 \\
& 29 \mathrm{~A} \\
\end{array}$ & $\begin{array}{l}\mathbf{N} \\
\mathbf{N} \\
\end{array}$ & $\begin{array}{r}5 \\
70 \\
\end{array}$ & $\begin{array}{l}\mathbf{L} \\
\mathbf{N} \\
\end{array}$ & $\begin{array}{l}\mathbf{N} \\
\mathbf{N} \\
\end{array}$ & $\begin{array}{l}20 \\
20 \\
\end{array}$ & $\begin{array}{l}\mathbf{N} \\
\mathbf{N} \\
\end{array}$ & $\begin{array}{l}\mathbf{3 0 0} \\
\mathbf{5 0 0} \\
\end{array}$ & $\begin{array}{l}150 \\
200 \\
\end{array}$ & $\mathbf{N}$ & $\begin{array}{l}20 \\
15 \\
\end{array}$ & $\begin{array}{l}\mathbf{N} \\
\mathbf{N} \\
\end{array}$ & $\begin{array}{l}50 \\
20 \\
\end{array}$ & $\begin{array}{l}\mathbf{3} \\
\mathbf{3} \\
\end{array}$ & $\begin{array}{ll}1.5 \\
\end{array}$ & $\begin{array}{l}\mathbf{5} \\
\mathbf{5} \\
\end{array}$ & $\begin{array}{r}0.5 \\
.3 \\
\end{array}$ \\
\hline \multicolumn{19}{|c|}{ Intermediate igneous rocks (quartz diorite) } \\
\hline $\begin{array}{l}31 \\
32 \\
33 \\
34 \\
35\end{array}$ & $\begin{array}{r}\text { AFE 212 } \\
213 \\
203 \\
217 \\
\text { ACE } 616\end{array}$ & $\begin{array}{rr}67 \mathrm{ACx} & 85 \\
89 \\
124 \\
133 \\
67 \mathrm{AHx} 229\end{array}$ & $\begin{array}{l}10 \\
L \\
L \\
10 \\
20\end{array}$ & $\begin{array}{r}10 \\
7 \\
5 \\
10 \\
15\end{array}$ & $\begin{array}{l}10 \\
10 \\
L \\
10 \\
30\end{array}$ & $\begin{array}{l}\mathbf{N} \\
\mathbf{N} \\
\mathbf{N} \\
\mathbf{N} \\
\mathbf{N}\end{array}$ & $\begin{array}{r}20 \\
20 \\
10 \\
15 \\
7\end{array}$ & $\begin{array}{l}\mathbf{N} \\
\mathbf{N} \\
\mathbf{N} \\
\mathbf{N} \\
10\end{array}$ & $\begin{array}{r}700 \\
700 \\
500 \\
1,000 \\
150\end{array}$ & $\begin{array}{l}200 \\
300 \\
200 \\
200 \\
100\end{array}$ & $\begin{array}{l}\mathbf{N} \\
\mathbf{N} \\
\mathbf{N} \\
\mathbf{N} \\
\mathbf{N}\end{array}$ & $\begin{array}{l}20 \\
20 \\
10 \\
15 \\
15\end{array}$ & $\begin{array}{l}\mathbf{N} \\
\mathbf{N} \\
\mathbf{N} \\
\mathbf{N} \\
\mathbf{N}\end{array}$ & $\begin{array}{r}150 \\
150 \\
100 \\
150 \\
70\end{array}$ & $\begin{array}{l}\mathbf{5} \\
\mathbf{5} \\
\mathbf{3} \\
\mathbf{3} \\
\mathbf{5}\end{array}$ & $\begin{array}{l}1 \\
1 \\
1 \\
1 \\
2\end{array}$ & $\begin{array}{l}\mathbf{7} \\
\mathbf{5} \\
\mathbf{5} \\
\mathbf{5} \\
\mathbf{2}\end{array}$ & $\begin{aligned} 1 \\
>1 \\
.5 \\
.5 \\
.3\end{aligned}$ \\
\hline $\begin{array}{l}36 \\
37 \\
38 \\
\end{array}$ & $\begin{array}{r}\text { ACF } 002 \\
003 \\
006 \\
\end{array}$ & $\begin{array}{l}103 \\
107 \\
118 \\
\end{array}$ & $\begin{array}{l}15 \\
15 \\
\mathrm{~N} \\
\end{array}$ & $\begin{array}{l}70 \\
70 \\
50 \\
\end{array}$ & $\begin{array}{r}20 \\
100 \\
70 \\
\end{array}$ & $\begin{array}{l}\mathbf{N} \\
\mathbf{N} \\
\mathbf{N}\end{array}$ & $\begin{array}{l}20 \\
20 \\
20 \\
\end{array}$ & $\begin{array}{l}\mathbf{N} \\
\mathbf{N} \\
\mathbf{N}\end{array}$ & $\begin{array}{l}\mathbf{3 0 0} \\
\mathbf{5 0 0} \\
\mathbf{3 0 0} \\
\end{array}$ & $\begin{array}{l}100 \\
100 \\
100 \\
\end{array}$ & $\begin{array}{l}\mathbf{N} \\
\mathbf{N} \\
\mathbf{N} \\
\end{array}$ & $\begin{array}{l}20 \\
20 \\
20 \\
\end{array}$ & $\begin{array}{l}\mathbf{N} \\
\mathbf{N} \\
\mathbf{L}\end{array}$ & $\begin{array}{l}150 \\
150 \\
150 \\
\end{array}$ & $\begin{array}{l}\mathbf{5} \\
\mathbf{5} \\
\mathbf{5} \\
\end{array}$ & $\begin{array}{l}1.5 \\
1.5 \\
2\end{array}$ & $\begin{array}{l}1 \\
1 \\
1 \\
\end{array}$ & $\begin{array}{l}.3 \\
.3 \\
.3 \\
\end{array}$ \\
\hline \multicolumn{19}{|c|}{ Granite rocks (quartz porphyry, felsite, aplite) } \\
\hline $\begin{array}{l}39 \\
40 \\
41 \\
\end{array}$ & $\begin{array}{r}\text { ACF 058 } \\
061 \\
\text { AGJ } 858 \\
\end{array}$ & $\begin{array}{c}67 \mathrm{AHX} 135 \mathrm{~B} \\
169 \\
56-\mathrm{H} 34 \mathrm{~A} \\
\end{array}$ & $\begin{array}{r}10 \\
\mathbf{N} \\
20 \\
\end{array}$ & $\begin{array}{r}5 \\
\mathbf{L}^{7} \\
\end{array}$ & $\begin{array}{l}50 \\
10 \\
15 \\
\end{array}$ & $\begin{array}{l}\mathbf{N} \\
\mathbf{N} \\
\mathbf{N}\end{array}$ & $\begin{array}{l}\mathbf{5} \\
\mathbf{N} \\
\mathbf{L}\end{array}$ & $\begin{array}{l}\mathbf{L} \\
\mathbf{N} \\
\mathbf{N}\end{array}$ & $\begin{array}{l}100 \\
200 \\
100 \\
\end{array}$ & $\begin{array}{l}30 \\
15 \\
\mathbf{L} \\
\end{array}$ & $\begin{array}{l}\mathbf{N} \\
\mathbf{N} \\
\mathbf{N}\end{array}$ & $\begin{array}{l}15 \\
\mathbf{L} \\
\mathrm{L} \\
\end{array}$ & $\begin{array}{l}\mathbf{N} \\
\mathbf{N} \\
\mathbf{N} \\
\end{array}$ & $\begin{array}{l}70 \\
70 \\
70 \\
\end{array}$ & $\begin{aligned} 2 \\
1.5 \\
.3 \\
\end{aligned}$ & $\begin{array}{l}0.3 \\
.5 \\
.07 \\
\end{array}$ & $\begin{array}{r}0.5 \\
.5 \\
.1 \\
\end{array}$ & $\begin{array}{c}0.3 \\
.1 \\
.07 \\
\end{array}$ \\
\hline$\underset{\text { deter }}{\text { Limits }}$ & $\begin{array}{l}\text { of } \\
\text { nination ... }\end{array}$ & . & 10 & 5 & 10 & 100 & $\mathbf{5}$ & 10 & 50 & 10 & 50 & 10 & 200 & 20 & 0.05 & 0.02 & 0.05 & 0.001 \\
\hline
\end{tabular}

stage where clear-cut zonal relations are apparent, but there are strong hints of zonation on three scales-ore body, local mineralized areas or belts, and throughout the district. The most convincing case for zoning can be made in the northern part of the district near the Golden Zone mine.

Published assay data on channel samples, mill tests, and drill cores from the Golden Zone ore body suggest a peripheral and possibly upward enrichment of copper or copper and gold relative to arsenic. Composite channel samples of the U.S. Bureau of Mines, cited previously, suggest that ore from the 100 -foot level has more copper and less arsenic than ore from the 200 -foot level, but with negligible difference in gold. Assays from the U.S. Bureau of Mines drill hole No. 1 (Mulligan and others, 1967) further suggest a peripheral enrichment of copper relative to gold at the eastern margin of the deposit:

\begin{tabular}{|c|c|c|c|}
\hline Samples & Location & $\begin{array}{c}\text { Copper } \\
\text { (percent) }\end{array}$ & $\begin{array}{c}\text { Gold } \\
\text { (oz. perton) }\end{array}$ \\
\hline $9-16$ & $\begin{array}{l}\text { Inferred east edge of } \\
\text { breccia pipe and adjacent } \\
\text { country rock }\end{array}$ & ... 0.47 & 0.08 \\
\hline $17-35$ & $\begin{array}{l}\text { Breccia pipe inside and } \\
\text { below samples } 9-16\end{array}$ & .14 & .17 \\
\hline
\end{tabular}

Enrichment of copper in the marginal parts of the deposit is supported by the fact that ore produced from 


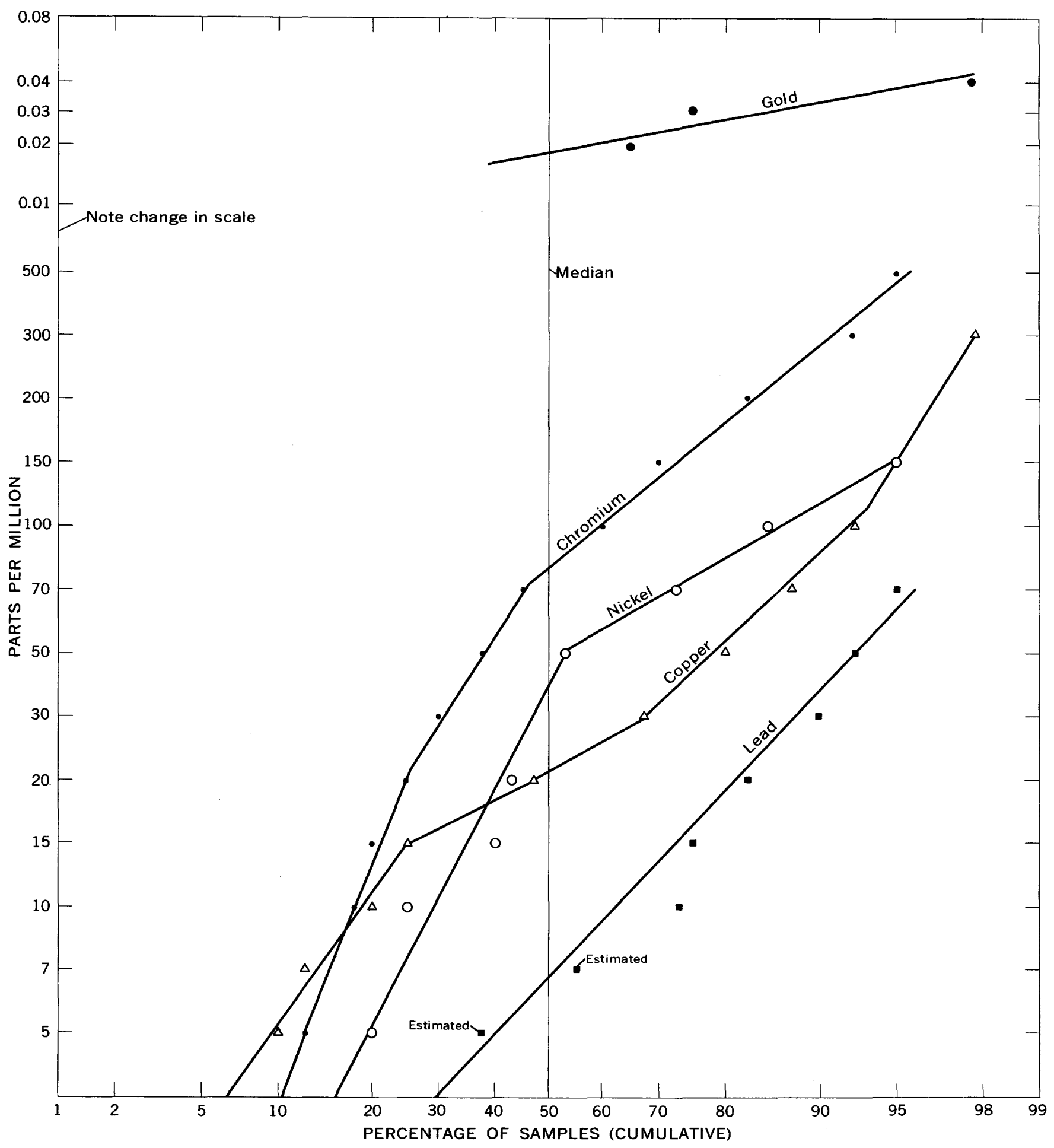

FigURE 2.-Frequency-distribution diagrams for gold, copper, lead, chromium, and nickel in bedrock.

this outer zone has a calculated assay of about 1.20 percent copper, which is much higher than the average copper content of the ore body.

On a somewhat larger scale, there is a suggestion from rock samples that deposits with more zinc, lead, and possibly silver exist to the east and south of the
Golden Zone deposit than in the deposit itsuif and nearby veins. The Golden Zone deposit and the nearby veins like the Little vein are predominantly arsenopyrite; sphalerite is present locally but is not abundant. The Mayflower and East veins exposed to the east contain higher proportions of galena and sphalerite and 


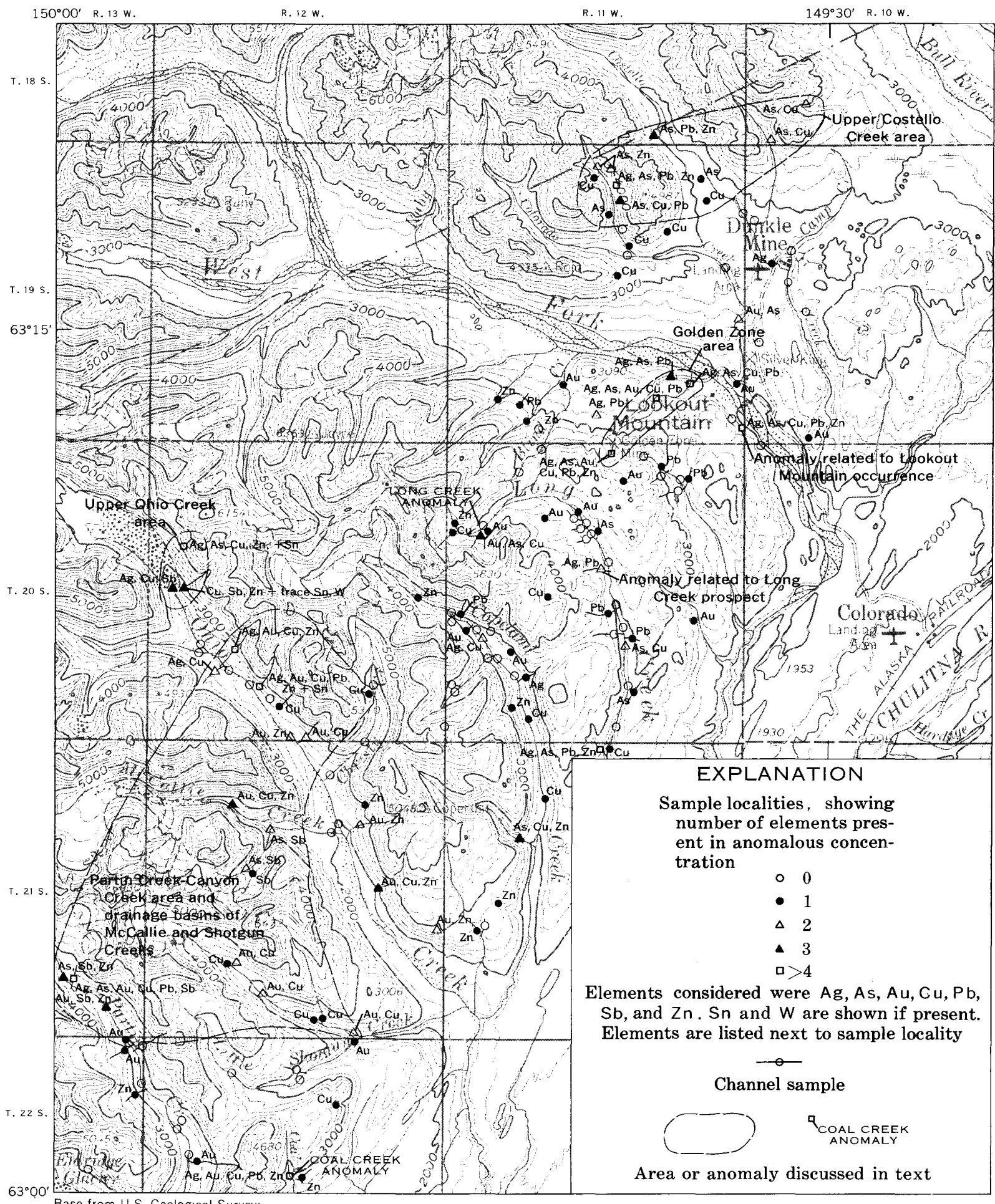
$63^{\circ} 00^{\prime} \frac{\text { Base from U.S. Geological Survey: }}{\text { Base }}$

1:250,000 Healy, 1956

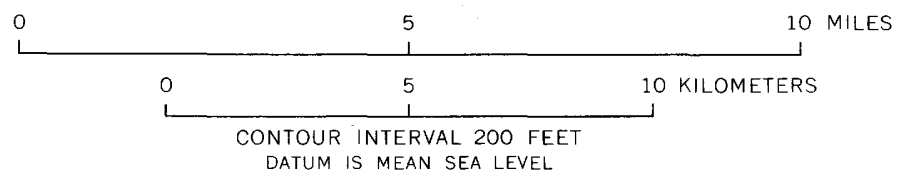

FIGURE 3.-Elements present in anomalous concentration in stream-sediment samples. 


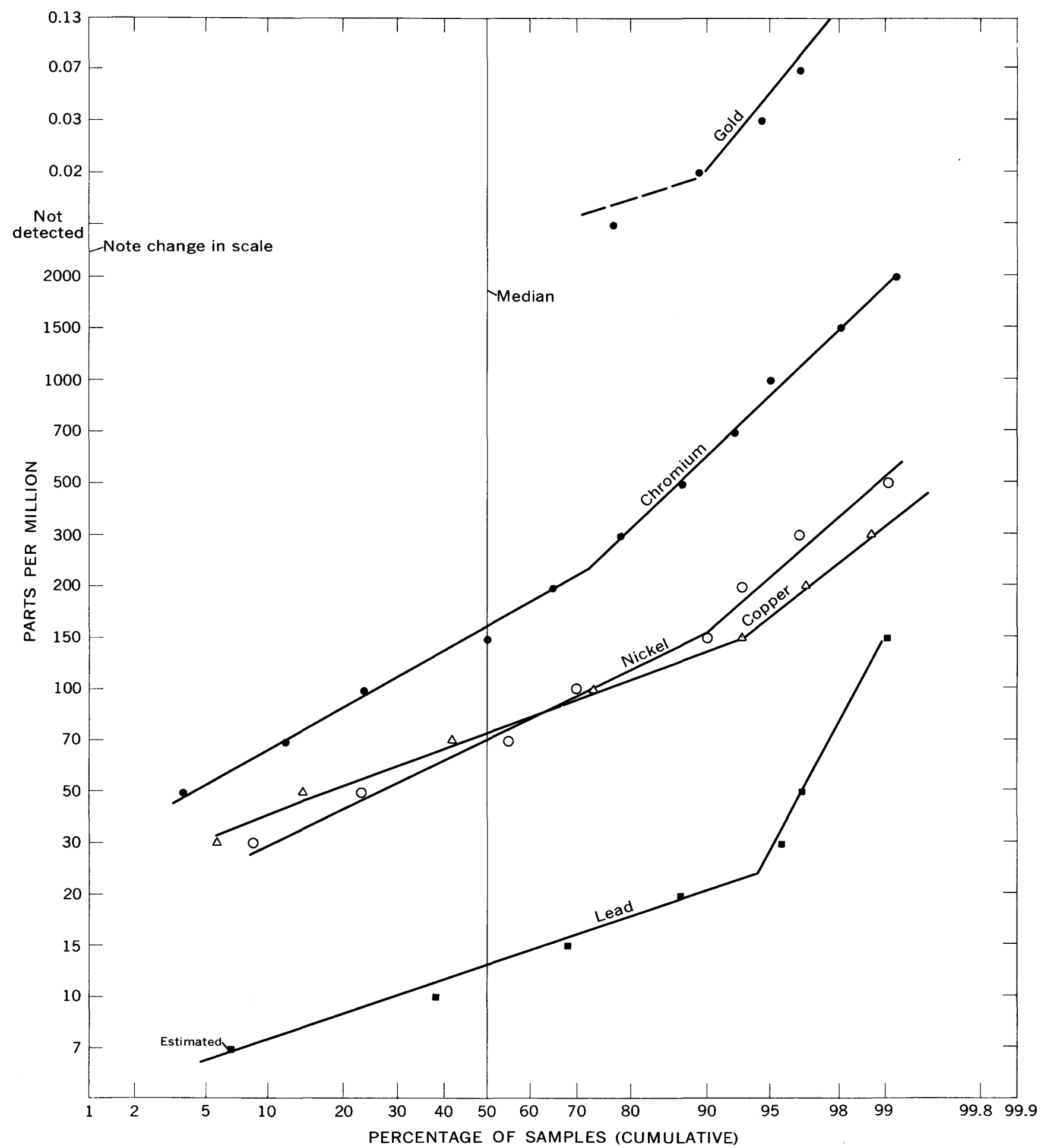

FIGURE 4.-Frequency-distribution diagrams for gold, chromium, copper, nickel, and lead in stream-sediment samples.

locally had high silver assays. Galena and sphalerite also occur on fracture surfaces within the Bryn Mawr fault zone to the east. The mineralized rock at the Lookout Mountain deposit, approximately 2 miles to the east, is characterized by silver, zinc, and lead, as are other nearby dike rocks (table 10). Analyses of stream-sediment samples in the Golden Zone area also show that zinc, lead, and silver apparently are enriched peripherally to the areas of highest copper and gold concentrations. 


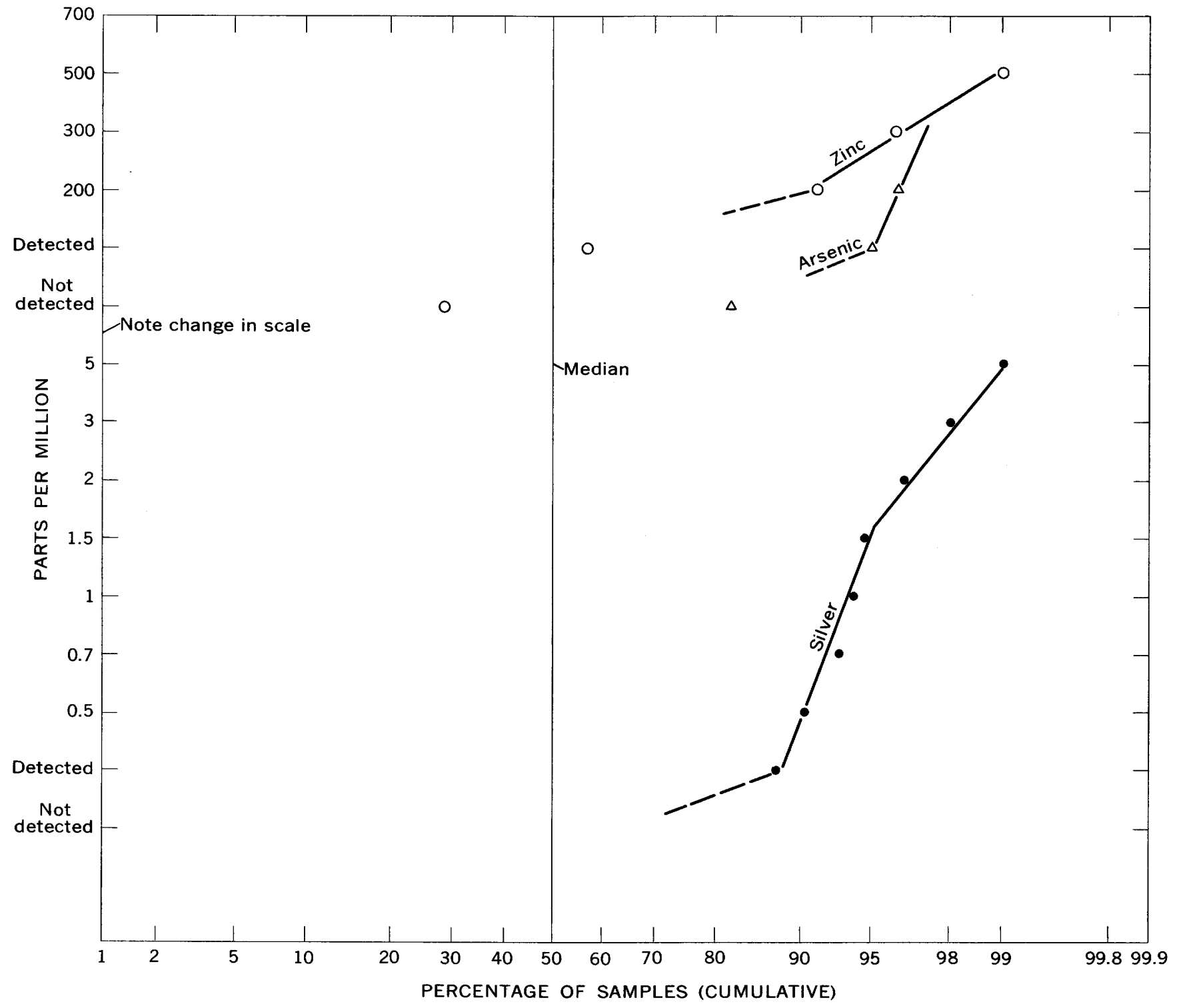

Figure 5.-Frequency-distribution diagrams for silver, zinc, and arsenic in stream sediments.

TABLE 7.-Comparison of medians and percent of element detection in bedrock and stream-sediment samples

[Median to nearest point or range in series 1, 1.5, 2, 3, 5, 7, 10, 15, and so on]

\begin{tabular}{|c|c|c|c|c|c|}
\hline & \multicolumn{2}{|c|}{ Stream sediments } & \multicolumn{2}{|l|}{ Bedrock } & \multirow[b]{2}{*}{ 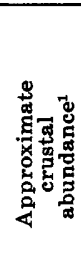 } \\
\hline & $\begin{array}{l}\text { Median } \\
(\mathrm{ppm})\end{array}$ & 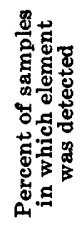 & $\frac{\text { Median }}{(\mathbf{p p m})}$ & 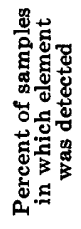 & \\
\hline $\begin{array}{l}\text { Ag } \\
\text { As } \\
\text { Au } \\
\text { Ar }\end{array}$ & $\begin{array}{c}<0.5 \\
<200 \\
\widetilde{\widetilde{F}}^{2} .001-.005 \\
70 \\
70 \\
70 \\
>10<15 \\
<200\end{array}$ & $\begin{array}{r}39 \\
18 \\
24 \\
\approx \mathbb{2}_{0}^{100} \\
\mathbb{\approx}_{>00}^{100} \\
>95 \\
41\end{array}$ & $\begin{array}{c}<0.5 \\
<200 \\
>701<.02 \\
70 \\
>30<50 \\
\quad< \\
\quad<200\end{array}$ & 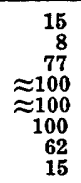 & $\begin{array}{l}{ }_{1.951}^{0.051} \\
{ }_{.004}^{.004} \\
30 \\
15 \\
15 \\
60\end{array}$ \\
\hline
\end{tabular}

1Abundance in high-calcium granitic rocks of Turekian and Wedepohl

2Estimate from projections on frequency-distribution diagram (fig. 4).
Zoning on a similar scale possibly exists in upper Ohio Creek, although the evidence is indirect. The tinbearing greisen and associated vein material in upper Ohio Creek and the deposits near Canyon Creek contain virtually the same metals-silver, copper, lead, zinc, antimony, and tin-but in different proportions. Arsenic is abundant at both places, but tin is proportionately higher at Ohio Creek and copper and zinc at Canyon Creek.

Regional-scale zoning is suggested by streamsediment data given in the preceding section, which show weakly anomalous amounts of zinc, silver, arsenic, and molybdenum on the northwest, north, and east sides of the northern part of the district. This kind of zoning corresponds to similar zoning peripheral to many mining districts. Molybdenum, though charac- 
teristically a centrally distributed element, may not be abnormal for it is known locally, as in the western part of the Central City district, Colorado, as a minor element of peripheral lead-zinc-silver deposits.

\section{ROCK ALTERATION}

Mineral deposits of the district are associated with several types of altered rocks. Argillic and propylitic facies are widely distributed near mineral deposits in detrital and volcanic rocks, respectively. Sericitic alteration is characteristic of porphyry near some deposits, and tactite and greisen are locally developed in rocks of favorable composition. Chemical data suggest widespread introduction of sulfur, arsenic, hydrogen, and carbon dioxide during alteration, although quantitative data are available only from the Golden Zone.

Very strongly altered rocks are exposed near the Golden Zone mine. The country rock of the region is siltstone and conglomerate (breccia) of the red-bed unit. Near the mine and especially along Bryn Mawr Creek, the rocks are pale green, argillaceous, and, where weathered, highly jarositic. They contain finely disseminated pyrite and locally arsenopyrite and other sulfides are present on fracture surfaces. On strike, the rocks in Long Creek are hematitic red beds, and it seems clear that the ferric iron of the red beds was reduced in the alteration process. A U.S. Bureau of Mines drill hole in Bryn Mawr Creek shows that the rock is highly argillized down to at least 300 feet, and similar-appearing argillic rock was found in the lowermost 25 feet of a Bureau of Mines 1,025-foot drill hole through the Golden Zone. These findings suggest that at least some of the argillic alteration is deep and hypogene.

The quartz diorite porphyry that contains the Golden Zone deposit is strongly altered near ore. The altered rocks are very pale brown and in places have a greenish tinge. The dominant alteration, evident from hand specimens and thin sections, took place during the formation of sericite, quartz, and iron-bearing carbonate. Comparison of chemical analyses, in gramequivalents per $1,000 \mathrm{cc}$, shows that the main chemical changes were the addition of $\mathrm{H}, \mathrm{CO}_{2}, \mathrm{As}$, and $\mathrm{S}$, and the loss of $\mathrm{Na}$ and the divalent cations $\mathrm{Fe}^{2+}, \mathrm{Mg}$, and $\mathrm{Ca}$ (table 8). The concentration of $\mathrm{Si}$ is virtually the same in altered and unaltered rocks, but the concentrations of $\mathrm{Al}$ and $\mathrm{Fe}^{3+}$ are slightly larger in the altered rocks.

Alteration calculations were made on the basis of both equal volume and gram-equivalents per equal volume. Comparison of the weight percent analyses suggests a loss of $\mathrm{SiO}_{2}$, but an appreciable difference in the density of altered and unaltered rocks offsets this. The conventional grams per 1,000 cc calculation, in tables 8 and 9 , shows the same relative changes as the gram-equivalent calculation but masks changes in elements of relatively light atomic weight, especially hydrogen (see Hemley and Jones, 1964, p. 544-546).

Trace-element analyses suggest the addition, during alteration, of silver, arsenic, boron, some cobalt and copper, and molybdenum, lead, and tin (table 9). Strontium and barium, like the major divalent cations, were partly removed. Zirconium and scandium apparently were nearly unaffected.

Thin sections show that propylitic alteration is char-

TABLE 8.-Chemical composition of altered and unaltered biotite quartz diorite porphyry from the Golden Zone stock and gains and losses in alteration

[Analysts: Standard rock analyses by E. Englemen and Elaine L. Munson:

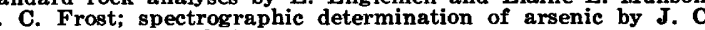
Hamilton; density by R. G. Wehr]

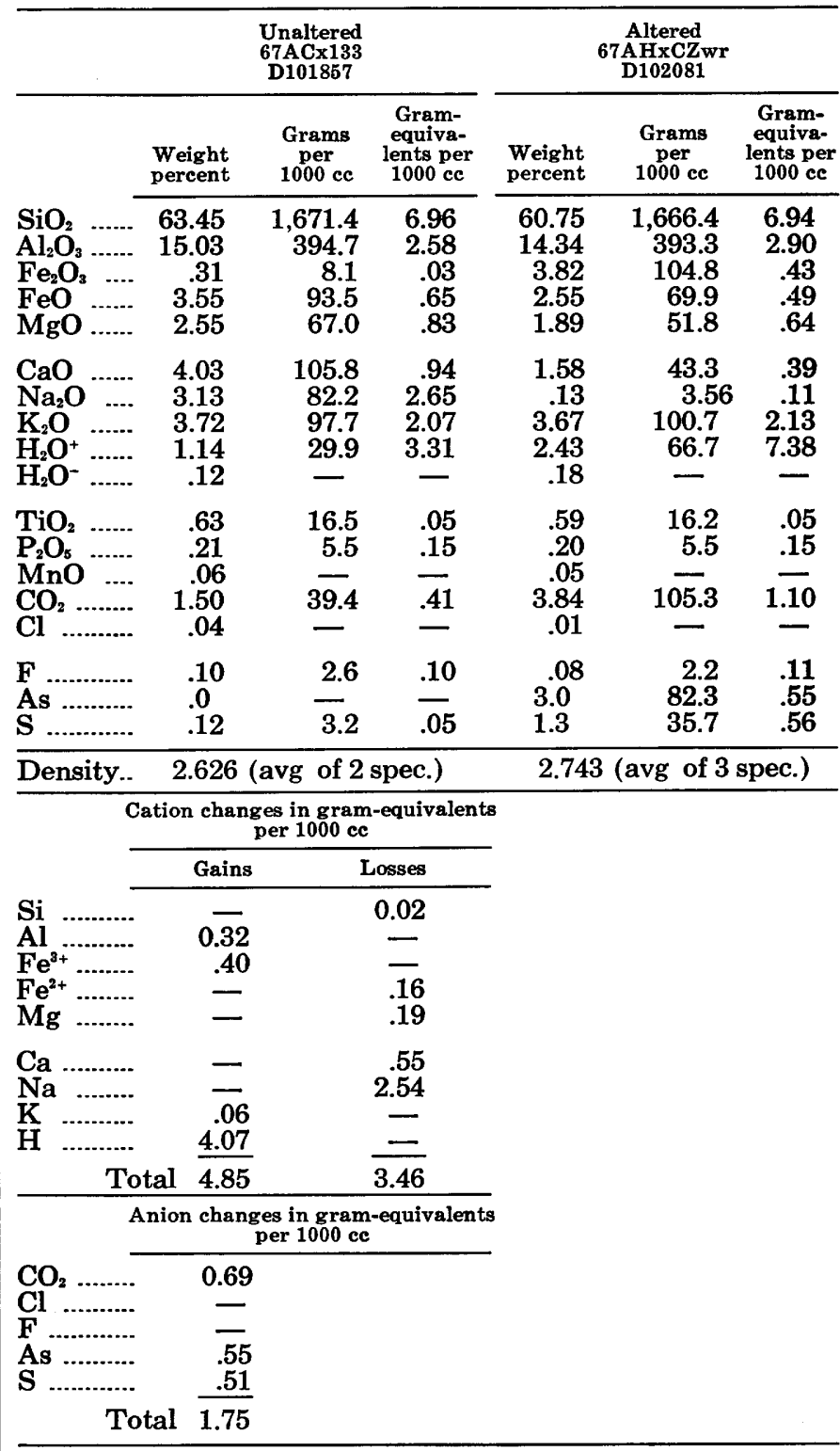


acteristic of basaltic hosts of mineralization in the Partin Creek and Canyon Creek areas and that argillic and locally sericitized rocks are present near mineral occurrences in siltstone and hornfels. At the Silver King prospect, pale-green tactite that is composed of garnet and epidote is in the calcareous hornfels in an area that is cut by numerous dikes of quartz diorite porphyry. Similar rocks probably exist in other limestone-bearing terranes of the region, as in the Partin Creek-Canyon Creek area. Greisen was found in the Ohio Creek tin-bearing granite stock. The greisen, principally a medium-grained pale-green to almost white rock, is composed of quartz, muscovite, arsenopyrite, and probably topaz; it contains strongly embayed remnant grains of albite-oligoclase from the parent igneous rock. Locally, the greisen contains stubby tourmaline crystals as much as 1-inch long; coarse-grained muscovite and quartz are interstitial to the tourmaline.

TABLE 9.-Trace-element composition of altered and unaltered biotite quartz diorite porphyry from the Golden Zone stock [Analysts, $J$. C. Hamilton and R. H. Heidel. Results given in parts per
million. $\mathbf{N}=$ not detected.]

\begin{tabular}{|c|c|c|}
\hline & $\begin{array}{c}\text { Unaltered } \\
\text { 67ACx133 } \\
\text { D101857 } \\
\end{array}$ & $\begin{array}{c}\text { Altered } \\
\text { 67AHxGZ } \\
\text { D102081 }\end{array}$ \\
\hline $\begin{array}{l}\text { Ag } \\
\text { As } \\
\text { Au } \\
\text { B } \\
\text { Ba }\end{array}$ & $\begin{array}{r}N \\
N \\
N \\
20 \\
3,000\end{array}$ & $\begin{array}{r}7 \\
30,000 \\
N \\
150 \\
500\end{array}$ \\
\hline $\begin{array}{l}\mathrm{Be} \\
\mathrm{Bi} \\
\mathrm{Cd} \\
\mathrm{Ce}\end{array}$ & $\begin{array}{r}\mathbf{1} \\
\mathbf{N} \\
\mathbf{N} \\
\mathbf{1 0}\end{array}$ & $\begin{array}{l}\mathbf{1} \\
\mathbf{N} \\
\mathbf{N} \\
30\end{array}$ \\
\hline $\begin{array}{l}\text { Cr } \\
\text { Cu } \\
\text { Ga } \\
\text { La } \\
\text { Li }\end{array}$ & $\begin{array}{r}70 \\
150 \\
50 \\
70 \\
\mathrm{~N}\end{array}$ & $\begin{array}{r}70 \\
300 \\
30 \\
\mathbf{N} \\
\mathbf{N}\end{array}$ \\
\hline $\begin{array}{l}\text { Mo } \\
\text { Nb } \\
\text { Ni } \\
\text { Pb } \\
\text { Sb }\end{array}$ & $\begin{array}{r}\mathrm{N} \\
10 \\
30 \\
10 \\
\mathrm{~N}\end{array}$ & $\begin{array}{r}5 \\
\mathbf{L} \\
20 \\
30 \\
\mathbf{N}\end{array}$ \\
\hline $\begin{array}{l}\text { Sc } \\
\text { Sn } \\
\text { Sr } \\
\text { V } \\
\text { W }\end{array}$ & $\begin{array}{r}20 \\
\mathbf{N} \\
1,500 \\
100 \\
\mathbf{N}\end{array}$ & $\begin{array}{r}15 \\
15 \\
100 \\
100 \\
\mathrm{~N}\end{array}$ \\
\hline $\begin{array}{l}\text { Y } \\
\text { Yb } \\
\mathbf{Z n} \\
\mathbf{Z r}\end{array}$ & $\begin{array}{r}20 \\
2 \\
\mathbf{N} \\
150\end{array}$ & $\begin{array}{r}10 \\
1 \\
\mathbf{N} \\
150\end{array}$ \\
\hline
\end{tabular}

\section{ORIGIN}

The epigenetic ore deposits, probably of early Tertiary age, are related in a general way to the hypabyssal igneous intrusive rocks of the area. They formed after the emplacement of the hypabyssal rocks and before the formation of coal-bearing beds of Oligocene age. A genetic relation of these deposits with igneous rocks is suggested partly because of close spatial association and partly because similar rock series elsewhere have associated mineral deposits of similar mineralogic character. The association of auriferous rocks with diorites and quartz diorites along the trend of the Alaska Range is a well-documented one, as shown in the Juneau gold belt (Spencer, 1906), at Valdez Creek (Ross, 1933b), and in the Slana area (Richter and Matson, 1968). The association of tin-bearing greisen with granite is worldwide.

\section{DESCRIPTION OF MINERALIZED AREAS AND PROSPECTS}

This part of the report describes individual occurrences or prospects, and if the amount of information warants, summarizes the areal geology. Areas or prospects are described in geographic order, starting with the northeastern part of the district and going generally southwestward. Some of the data are from recent circulars or from open-file reports. Other data on prospects long inactive or poorly exposed are taken from reports by Ross (1933a) and Capps (1919) and from unpublished material.

\section{AREA NEAR COSTELLO CREEK}

The part of the district north and east of Costello Creek near the Dunkle coal mine and in the drainage area of upper Costello and Colorado Creeks contains local occurrences of mineralized rock (pl. 1).

\section{COSTELLO CREEK OCCURRENCE}

Sulfides are present on fracture surfaces and as disseminated grains in fine grained locally garnetiferous hornblende diorite porphyry over an area about $1 / 4$ mile wide by $3 / 4$ mile long east of Costello Creek. Porphyry that is near the localities of samples 1 and 2 (pl. 1 and table 10) is estimated to contain about 1-3 percent sulfides with arsenopyrite, pyrite, pyrrhotite, and chalcopyrite visible megascopically. At locality 3 , the rock is a brecciated fine-grained porphyry with minor hornfels. At sample localities 3,4 , and 5, sulfiides are estimated to make up $1 / 2-2$ percent of the rock. A granite porphyry dike at locality 6 , did not contain metals in anomalous concentration.

\section{CAMP CREEK OCCURRENCE}

Altered and weakly mineralized fine-grained porphyry locally protrudes through coal-bearing Tertiary rocks (pl. 1) for approximately $1 / 4$ mile in upper Camp Creek in sec. 5 and near the center of sec. 9; both occurrences are in T. 19 S., R. 10 W., north of the Dunkle coal mine. 
The highest metal concentration in samples from the Camp Creek occurrence was $0.6 \mathrm{ppm}$ gold, $500 \mathrm{ppm}$ copper, and 1,000 ppm zinc (sample 13, table 10). Other samples (8-12) contained appreciably less metal, but mineralization in all samples except No. 8 was indicated by the detection of zinc, bismuth, and antimony.

The occurrances in Camp Creek and in mineralized rock north of Costello Creek suggest that mineral deposits may be buried beneath the extensive cover of Tertiary and Quaternary rocks and sediments at the north end of the Upper Chulitna district.

\section{OTHER OCCURRENCES}

Sample localities 14 through 18 (pl. 1, table 10) are in the upper Costello Creek and Colorado Creek drainages. Copper minerals at localities 14 and 17 occur in or near small granite plugs. An anomalous concentration of tin was found at one copper-bearing locality (14), and tin, beryllium, and silver characterize an apparently unmineralized igneous rock at locality 15 . Sample 18 is from an altered mafic dike.

\section{SILVER KING AREA}

The Silver King area (fig. 6 is approximately bounded on the west by Colorado Creek and on the north and east by Costello Creek. The area has numerous occurrences of metallic minerals, some previously described by Ross (1933a, p. 328-330) and Capps (1919, p. 223225).

Rock units that include argillite-graywacke, limestone, conglomerate, and tuffaceous greenstone strike northeastward but are well exposed only in the canyons of Colorado and Costello Creeks. The limestone and calcareous argillite of the southwestern part of the area (fig. 6A) strike toward the Silver King prospect and apparently are the unmetamorphosed equivalents of the hornfels and tactite that are the country rocks for most of the prospect (fig. 6B). Igneous rocks, also mainly in northeast-striking units, include serpentinite, gabbro and basalt, and quartz diorite porphyry. The porphyry forms small dikelike bodies at the Silver King prospect (fig. $6 B$ ) and larger dikelike or podlike masses in the canyons of Colorado and Costello Creeks.

The Upper Chulitna fault crosses the area subparallel to the strike of rock units; it is well exposed in Colorado Creek and in Costello Creek near the Lucrata prospect. The mineralized part of the fault is referred to as the Lucrata segment (fig. 6A).

\section{SILVER KING PROSPECT}

The Silver King prospect is mainly in an area of hornfels, calc-hornfels, and tactite cut by small northeastward-trending dikes of quartz diorite porphyry.

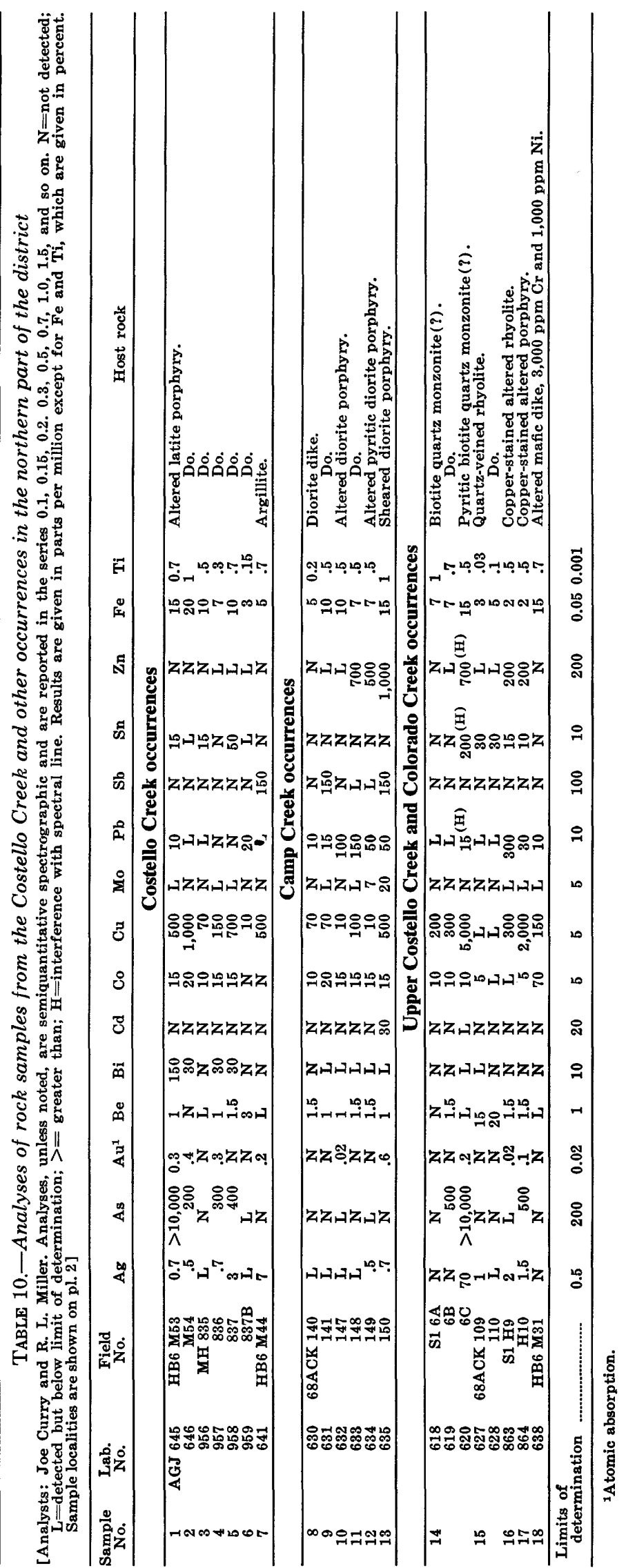




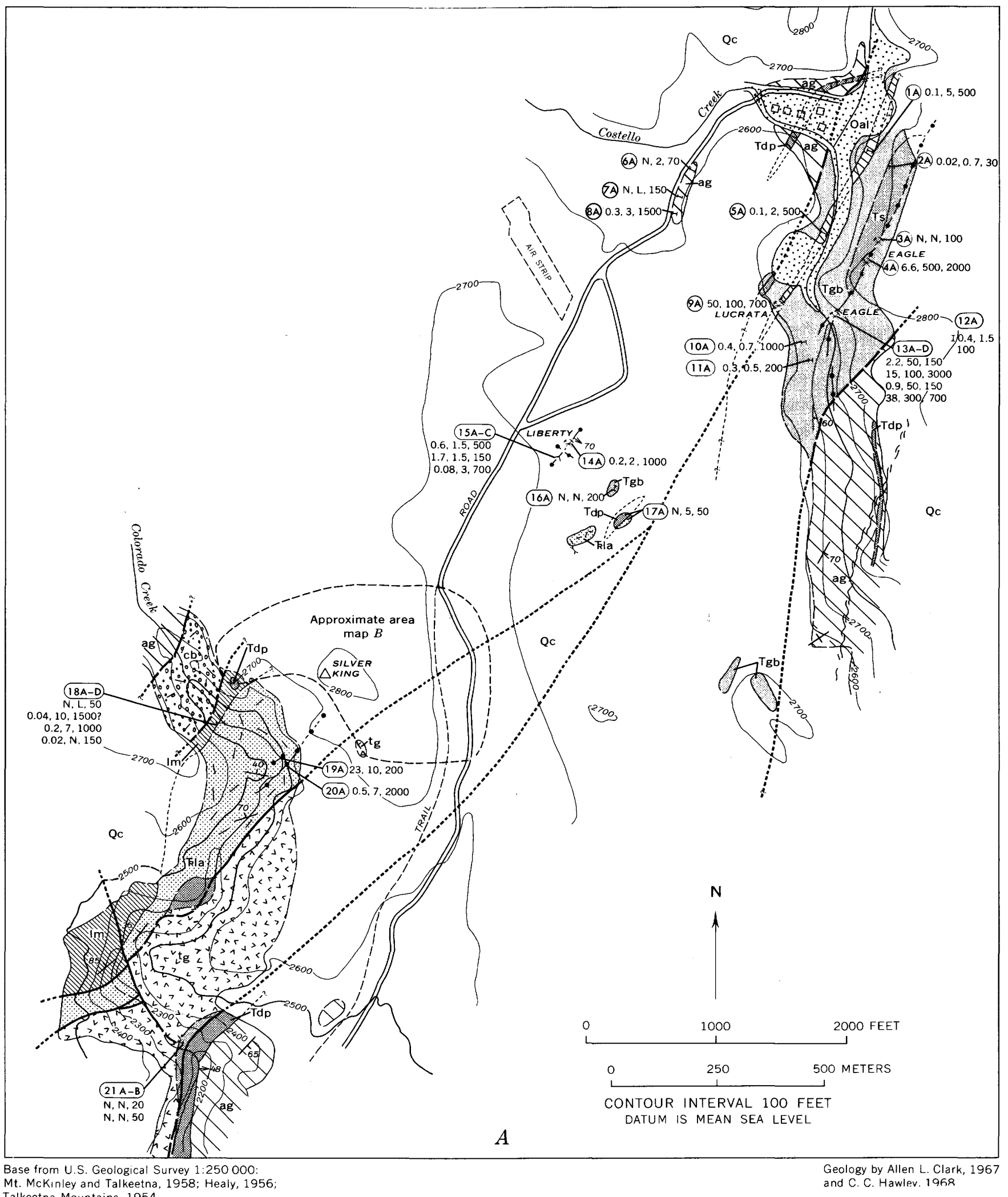

Mt. McKinley and Talkeetna, 1958; Healy, 1956; 


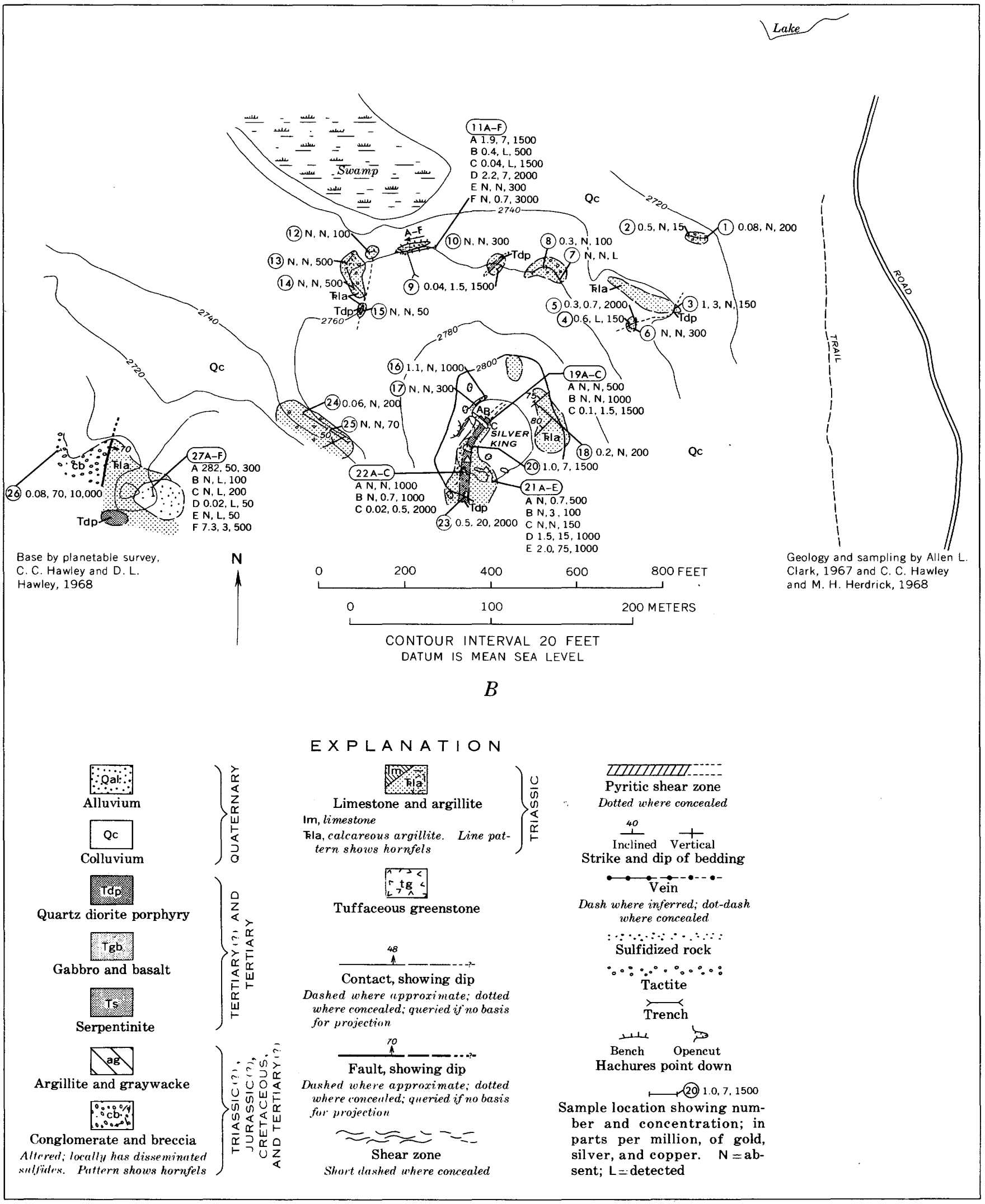

$B$, The Silver King prospect. 
Although the exposures are poor (fig. $6 B$ ), the sulfides, mainly pyrrhotite, are found in most outcrops within an area of about $400-800$ feet. The richest sulfide rocks occur on a round knob that has been extensively trenched and on an isolated knob 400 feet westsouthwest that has not been prospected.

Partial results of sampling of the Silver King prospect are shown in figure $6 B$ and in table 11. Analyses from the main trenched area show a trace to about 2 ppm gold in about half of the samples, anomalous amounts of copper in most, and silver in a few. Arsenic and antimony are locally abundant, and the characteristic trace elements of the district-bismuth and tin-are present in many samples. Stibnite is present at site 21 (fig. $6 B$ ) and in Colorado Creek below the prospect at sample sites $19 \mathrm{~A}$ and $20 \mathrm{~A}$ of figure $6 \mathrm{~A}$; $23 \mathrm{ppm}$ gold was detected in material at site $19 \mathrm{~A}$. Arsenopyrite is abundant at $19,20,21$, and 22 (fig. $6 B$ ) and in a sulfide-rich mass southwest of the main sampled area (site 27); here the richest arsenic samples contain 282 and $7.3 \mathrm{ppm}$ gold. The highest concentration of copper that was found was in highly altered conglomerate and breccia at site 26. Because terrain at this site is extremely precipitous, additional samples could not be obtained, but the conglomerate and breccia unit is inferred to project through on a northeasterly trend west and north of the main prospected area.

Because the numerous occurrences of metallic minerals and abundant tactite and hornfels suggested an intrusive nearby, the area was studied by geophysical techniques. The results are discussed in the following section.

\section{OTHER PROSPECTS AND OCCURRENCES}

The Silver King area (fig. 6A) contains the Eagle, Lucrata, and Liberty prospects and a few isolated

TABLE 11.- Analyses of rock samples from the Silver King prospect

[Analysts: E. E. Martinez, A. L. Meier, R. L. Miller, T. A. Roemer, J. E. Troxel, and Claude Huffman, Jr. Analyses, unless noted, are semiquantitative spectrographic and are reported in the series $0.1,0.15,0.2,0.3,0.5,0.7,1.0,1.5$, and so on. $\mathrm{N}=$ not detected; $\mathrm{L}=$ detected but below limit of deter-
mination; $>$ greater than. $\mathrm{H}=$ interference with spectral line. Results are given in parts per million except for Fe, which is given in percent.
Sample localities shown in figure $7 \mathrm{~B}]$

\begin{tabular}{|c|c|c|c|c|c|c|c|c|c|c|c|c|c|c|c|c|}
\hline $\begin{array}{l}\text { Sampl } \\
\text { No. }\end{array}$ & $\begin{array}{l}\text { le Lab. } \\
\text { No. }\end{array}$ & $\begin{array}{l}\text { Field } \\
\text { No. }\end{array}$ & Ag & As & $A u^{x}$ & $\mathbf{B i}$ & Co. & $\mathrm{Cu}$ & Mo & $\mathbf{N i}$ & $\mathrm{Pb}$ & $\mathbf{S b}$ & Sn & Zn & $\mathbf{F e}$ & Host rock \\
\hline $\begin{array}{l}1 \\
2 \\
3 \\
4 \\
5\end{array}$ & $\begin{array}{r}\text { AG5 } 647 \\
648 \\
649 \\
650 \\
651\end{array}$ & $\begin{array}{r}\text { HB6 M58A } \\
58 \mathrm{~B} \\
59 \\
60 \mathrm{~A} \\
60 \mathrm{~B}\end{array}$ & $\begin{array}{l}\mathbf{N} \\
N \\
N \\
L \\
0.7\end{array}$ & $\begin{array}{l}\mathbf{N} \\
\mathbf{N} \\
\mathbf{N} \\
\mathbf{L} \\
\mathbf{N}\end{array}$ & $\begin{array}{l}0.08 \\
\mathrm{~N} \\
1.3 \\
.3 \\
.06\end{array}$ & $\begin{array}{l}\mathbf{L} \\
\mathbf{L} \\
\mathbf{N} \\
\mathbf{1 0} \\
\mathbf{N}\end{array}$ & $\begin{array}{l}15 \\
15 \\
15 \\
15 \\
20\end{array}$ & $\begin{array}{r}15 \\
200 \\
150 \\
150 \\
2,000\end{array}$ & $\begin{array}{l}\mathrm{L} \\
\mathbf{N} \\
\mathrm{L} \\
\mathrm{L} \\
\mathrm{N}\end{array}$ & $\begin{array}{l}\mathbf{7 0} \\
\mathbf{5 0} \\
\mathbf{5 0} \\
\mathbf{5 0} \\
\mathbf{7 0}\end{array}$ & $\begin{array}{l}\mathrm{L} \\
\mathrm{L} \\
\mathrm{L} \\
15 \\
15\end{array}$ & $\begin{array}{l}\mathbf{N} \\
\mathbf{N} \\
\mathbf{N} \\
\mathbf{N} \\
\mathbf{N}\end{array}$ & $\begin{array}{l}\mathbf{N} \\
\mathbf{N} \\
\mathbf{N} \\
\mathbf{N} \\
\mathbf{L}\end{array}$ & $\begin{array}{r}300 \\
\mathbf{L} \\
500 \\
N \\
N\end{array}$ & $\begin{array}{l}10 \\
10 \\
20 \\
5 \\
15\end{array}$ & $\begin{array}{l}\text { Contact Metamorphased argillite. } \\
\text { Tactite. } \\
\text { Do. } \\
\text { Contact Metamorphased argillite. } \\
\text { Diorite dike. }\end{array}$ \\
\hline $\begin{array}{r}6 \\
7 \\
8 \\
9 \\
10\end{array}$ & $\begin{array}{l}652 \\
653 \\
654 \\
655 \\
656\end{array}$ & $\begin{array}{l}60 \mathrm{C} \\
61 \mathrm{~A} \\
61 \mathrm{~B} \\
62 \mathrm{~A} \\
62 \mathrm{~B}\end{array}$ & $\begin{array}{l}\mathbf{N} \\
\mathbf{N} \\
\mathbf{N} \\
1.5 \\
\mathbf{N}\end{array}$ & 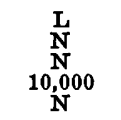 & $\begin{array}{l}\mathrm{N} \\
\mathbf{N} \\
.3 \\
.04 \\
\mathbf{N}\end{array}$ & $\begin{array}{r}\mathbf{N} \\
10 \\
10 \\
\mathbf{N} \\
100\end{array}$ & $\begin{array}{l}15 \\
10 \\
10 \\
20 \\
10\end{array}$ & $\begin{array}{r}300 \\
L_{10} \\
1,500 \\
300\end{array}$ & $\begin{array}{l}\mathbf{N} \\
\mathbf{L} \\
\mathbf{N} \\
\mathbf{N}\end{array}$ & $\begin{array}{r}70 \\
70 \\
50 \\
30 \\
150\end{array}$ & $\begin{array}{l}\mathrm{L} \\
\mathrm{L} \\
\mathrm{L} \\
\mathrm{L} \\
15\end{array}$ & $\begin{array}{l}\mathbf{N} \\
\mathbf{N} \\
\mathbf{L} \\
\mathbf{N} \\
\mathbf{N}\end{array}$ & $\begin{array}{l}\mathrm{N} \\
30 \\
30 \\
\mathrm{~L} \\
\mathbf{5 0}\end{array}$ & $\begin{array}{l}\mathbf{N} \\
\mathbf{L} \\
\mathbf{L} \\
\mathbf{L} \\
\mathbf{N}\end{array}$ & $\begin{array}{r}10 \\
20 \\
15 \\
15 \\
7\end{array}$ & $\begin{array}{l}\text { Argillite. } \\
\text { Tactite. } \\
\text { Limestone. } \\
\text { Tactite. } \\
\text { Diorite dike. }\end{array}$ \\
\hline $\begin{array}{r}11 \mathbf{A} \\
\mathbf{B} \\
\mathbf{C} \\
\mathbf{D} \\
\mathbf{E}\end{array}$ & $\begin{array}{l}657 \\
658 \\
659 \\
660 \\
661\end{array}$ & $\begin{array}{l}63 \mathrm{~A} \\
63 \mathrm{~B} \\
63 \mathrm{C} \\
63 \mathrm{D} \\
63 \mathrm{E}\end{array}$ & $\begin{array}{l}{ }^{7} \mathrm{~L} \\
\mathrm{~L} \\
\mathrm{7} \\
\mathrm{N}\end{array}$ & $\begin{array}{r}>10,000 \\
>10,000 \\
\mathbf{N} \\
>10,000 \\
\mathbf{3 0 0}\end{array}$ & $\begin{array}{l}1.9 \\
.4 \\
.04 \\
2.2 \\
\text { N }\end{array}$ & $\begin{array}{r}50 \\
\mathrm{~L} \\
100 \\
\mathrm{~L} \\
\mathrm{~L}\end{array}$ & $\begin{array}{r}70 \\
20 \\
7 \\
1,50 \\
15\end{array}$ & $\begin{array}{r}1,500 \\
500 \\
1,500 \\
2,000 \\
300\end{array}$ & $\begin{array}{l}\mathbf{N} \\
\mathbf{N} \\
\mathbf{N} \\
\mathbf{3 0} \\
\mathbf{L}\end{array}$ & $\begin{array}{r}20 \\
30 \\
70 \\
200 \\
70\end{array}$ & $\begin{array}{l}30 \\
10 \\
L \\
15 \\
10\end{array}$ & $\begin{array}{l}\mathrm{L} \\
\mathbf{N} \\
\mathbf{N} \\
\mathrm{N}^{150}\end{array}$ & $\begin{array}{l}\mathbf{N} \\
15 \\
\mathbf{N} \\
\mathbf{N} \\
\mathbf{N}\end{array}$ & $\begin{array}{l}\mathbf{N} \\
\mathbf{N} \\
\mathbf{N} \\
\mathbf{L} \\
\mathbf{L}\end{array}$ & $\begin{array}{r}20 \\
15 \\
20 \\
>20 \\
15\end{array}$ & $\begin{array}{l}\text { Tactite. } \\
\text { Diorite dike. } \\
\text { Tactite. } \\
\text { Do. } \\
\text { Diorite dike. }\end{array}$ \\
\hline $\begin{array}{l}12^{F} \\
13 \\
15\end{array}$ & $\begin{array}{l}662 \\
663 \\
664 \\
665 \\
666\end{array}$ & $\begin{array}{l}63 \mathrm{~F} \\
64 \\
65 \mathrm{~A} \\
65 \mathrm{~B} \\
65 \mathrm{C}\end{array}$ & $\begin{array}{l}\dot{N}^{7} \\
\mathbf{N} \\
\mathbf{N}\end{array}$ & $\begin{array}{l}1,500 \\
\mathbf{N} \\
\mathbf{N} \\
\mathbf{N}\end{array}$ & $\begin{array}{l}\mathbf{N} \\
\mathbf{N} \\
\mathbf{N} \\
\mathbf{N}\end{array}$ & $\begin{array}{l}\mathbf{L} \\
\mathbf{L} \\
\mathbf{N} \\
\mathbf{N} \\
\mathbf{L}\end{array}$ & $\begin{array}{l}10 \\
15 \\
15 \\
15 \\
15\end{array}$ & $\begin{array}{r}1,500 \\
10 \\
500 \\
500 \\
50\end{array}$ & $\begin{array}{l}\mathbf{N} \\
\mathbf{N} \\
\mathbf{N} \\
\mathbf{N}\end{array}$ & $\begin{array}{r}70 \\
70 \\
100 \\
100 \\
70\end{array}$ & $\begin{array}{l}10 \\
15 \\
N \\
N \\
L\end{array}$ & $\begin{array}{l}\mathbf{N} \\
\mathbf{N} \\
\mathbf{N} \\
\mathbf{N} \\
\mathbf{N}\end{array}$ & $\begin{array}{l}\mathrm{L} \\
\mathrm{N} \\
15 \\
\mathbf{3 0} \\
\mathrm{N}\end{array}$ & $\begin{array}{l}\mathbf{N} \\
\mathbf{L} \\
\mathbf{L} \\
\mathbf{L} \\
\mathbf{L}\end{array}$ & $\begin{array}{l}20 \\
10 \\
20 \\
20 \\
15\end{array}$ & $\begin{array}{l}\text { Tactite. } \\
\text { Limestone } \\
\text { Tactite. } \\
\text { Do. } \\
\text { Diorite dike. }\end{array}$ \\
\hline $\begin{array}{l}16 \\
17 \\
18 \\
19 \mathrm{~A} \\
\mathrm{~B}\end{array}$ & $\begin{array}{l}667 \\
668 \\
669 \\
670 \\
671\end{array}$ & $\begin{array}{l}66 \\
67 \\
68 \\
69 \mathrm{~A} \\
69 \mathrm{~B}\end{array}$ & $\begin{array}{l}\mathbf{N} \\
\mathbf{N} \\
\mathbf{N} \\
\mathbf{N} \\
\mathbf{N}\end{array}$ & $\begin{array}{c}\mathbf{N} \\
\mathbf{N} \\
\mathbf{N} \\
700 \\
10,000\end{array}$ & $\begin{array}{l}1.1 \\
\mathbf{N} \\
.2 \\
\mathbf{N}\end{array}$ & $\begin{array}{l}\mathbf{N} \\
70 \\
\mathbf{N} \\
\mathbf{L} \\
\mathbf{L}\end{array}$ & $\begin{array}{r}15 \\
15 \\
7 \\
15 \\
20\end{array}$ & $\begin{array}{r}200 \\
1,000 \\
300 \\
500 \\
1,000\end{array}$ & $\begin{array}{l}\mathbf{N} \\
\mathbf{N} \\
\mathbf{L} \\
\mathbf{N}\end{array}$ & $\begin{array}{r}70 \\
70 \\
100 \\
100 \\
100\end{array}$ & $\begin{array}{r}20 \\
\mathbf{L} \\
20 \\
\mathbf{L} \\
\mathbf{L}\end{array}$ & $\begin{array}{l}\mathbf{N} \\
\mathbf{N} \\
\mathbf{N} \\
\mathbf{N} \\
\mathbf{N}\end{array}$ & $\begin{array}{l}\mathbf{N} \\
\mathbf{N} \\
\mathbf{N} \\
\mathbf{N}\end{array}$ & $\begin{array}{c}\mathbf{N} \\
200 \\
\mathbf{L} \\
\mathbf{L}\end{array}$ & $\begin{array}{r}10 \\
20 \\
15 \\
20 \\
720\end{array}$ & $\begin{array}{l}\text { Silicious argillite. } \\
\text { Tactite. } \\
\text { Do. } \\
\text { Diorite dike. } \\
\text { Tactite. }\end{array}$ \\
\hline $\begin{array}{r}20 \\
20 \\
21 A \\
\text { B } \\
\text { C }\end{array}$ & $\begin{array}{l}672 \\
673 \\
674 \\
675 \\
676\end{array}$ & $\begin{array}{l}69 \mathrm{C} \\
70 \\
71 \mathrm{~A} \\
71 \mathrm{~B} \\
71 \mathrm{C}\end{array}$ & $\begin{array}{l}1.5 \\
7 \\
.7 \\
\stackrel{3}{N}\end{array}$ & $\begin{array}{r}>10,000 \\
>10,000 \\
500 \\
500 \\
L\end{array}$ & $\begin{array}{r}.1 \\
1.0 \\
\mathbf{N} \\
\mathbf{N}\end{array}$ & $\begin{array}{c}30 \\
50 \\
\mathbf{L} \\
15 \\
\mathbf{N}\end{array}$ & $\begin{array}{r}30 \\
150 \\
10 \\
10 \\
15\end{array}$ & $\begin{array}{r}1,800 \\
1,500 \\
500 \\
100 \\
150\end{array}$ & $\begin{array}{l}5 \\
\mathbf{L} \\
N \\
N \\
\mathrm{~L}\end{array}$ & $\begin{array}{l}50 \\
70 \\
30 \\
30 \\
50\end{array}$ & $\begin{array}{r}15 \\
70 \\
15 \\
10 \\
\mathrm{~L}\end{array}$ & $\begin{array}{l}\mathrm{L}_{500} \\
\mathrm{~N}^{100} \\
\mathrm{~N}^{\mathrm{N}}\end{array}$ & $\begin{array}{l}20 \\
15 \\
\mathrm{~N} \\
15 \\
\mathrm{~N}\end{array}$ & $\begin{array}{r}\mathrm{L} \\
200 \\
\mathbf{N} \\
\mathbf{N} \\
\mathbf{N}\end{array}$ & $\begin{array}{r}10 \\
20 \\
10 \\
15 \\
5\end{array}$ & $\begin{array}{l}\text { Diorite dike. } \\
\text { Tactite. } \\
\text { Contact metamorphased argillite. } \\
\text { Diorite dike. } \\
\text { Do. }\end{array}$ \\
\hline $\begin{array}{r}\underset{\mathbf{E}}{21 \mathrm{D}} \\
\underset{\mathbf{E}}{22 \mathrm{~A}} \\
\underset{\mathbf{B}}{\mathrm{C}}\end{array}$ & $\begin{array}{r}\text { AGJ } 677 \\
678 \\
679 \\
680 \\
681\end{array}$ & $\begin{array}{r}\text { HB6 M71D } \\
\mathbf{E} \\
\text { M72 } \\
\mathbf{B} \\
\mathbf{C}\end{array}$ & $\begin{array}{l}15 \\
>5 \\
N^{1} \\
0.7 \\
.5\end{array}$ & $\begin{array}{r}1,500 \\
700 \\
500 \\
200 \\
200\end{array}$ & $\begin{array}{l}1.8 \\
2.0 \\
\mathrm{~N} \\
\mathrm{~N} \\
.02\end{array}$ & $\begin{array}{r}\mathrm{L} \\
\mathrm{N} \\
\mathrm{L} \\
10 \\
10\end{array}$ & $\begin{array}{c}7 \\
\mathrm{~L} \\
15 \\
10 \\
7\end{array}$ & $\begin{array}{l}1,000 \\
1,000 \\
1,000 \\
1,000 \\
1,000\end{array}$ & $\begin{array}{l}\mathbf{N} \\
\mathbf{L} \\
\mathbf{L} \\
\mathbf{L} \\
\mathbf{5}\end{array}$ & $\begin{array}{l}\mathbf{5 0} \\
\mathbf{L} \\
\mathbf{5 0} \\
30 \\
\mathbf{3 0}\end{array}$ & $\begin{array}{r}\mathrm{L} \\
1,500 \\
10 \\
10 \\
10\end{array}$ & $\begin{array}{r}2,000 \\
>10,000 \\
1,000 \\
L^{150}\end{array}$ & $\begin{array}{l}N \\
N \\
20 \\
10 \\
10\end{array}$ & $\begin{array}{l}\mathbf{N} \\
\mathbf{N} \\
\mathbf{L} \\
\mathbf{N} \\
\mathbf{N}\end{array}$ & $\begin{array}{l}20 \\
.2 \\
15 \\
15 \\
15\end{array}$ & $\begin{array}{l}\text { Tactite. } \\
\text { Stibnite. } \\
\text { Diorite dike. } \\
\text { Tactite. } \\
\text { Diorite dike. }\end{array}$ \\
\hline $\begin{array}{l}23 \\
24 \\
25 \\
27 \\
27\end{array}$ & $\begin{array}{r}682 \\
683 \\
684 \\
617 \\
\text { ACK } 018\end{array}$ & $\begin{array}{r}\text { M73 } \\
\text { M74A } \\
\text { M74B } \\
\text { SK41 } \\
\text { 67ACK } 162\end{array}$ & $\begin{array}{l}20 \\
\mathbf{N} \\
\mathbf{N} \\
\mathbf{7 0} \\
\mathbf{5 0}\end{array}$ & $\underset{\substack{\mathbf{N} \\
\underset{10,000^{2} 2}{\mathbf{N}}}}{\mathbf{H}}$ & $\begin{array}{l}.5 \\
\stackrel{5}{N} \\
.06 \\
.08\end{array}$ & $\begin{array}{l}\underset{70}{N} \\
\stackrel{L}{N} \\
>1,000\end{array}$ & $\begin{array}{r}70 \\
15 \\
15 \\
150 \\
150\end{array}$ & $\begin{array}{r}2,000 \\
70 \\
200 \\
10,000 \\
300\end{array}$ & $\begin{array}{l}\mathbf{N} \\
\mathrm{L} \\
\mathrm{L} \\
\mathbf{N} \\
\mathbf{N}\end{array}$ & $\begin{array}{c}30 \\
70 \\
100 \\
500 \\
5\end{array}$ & $\begin{array}{c}10 \\
N \\
L \\
20 \\
200\end{array}$ & $\begin{array}{l}200 \\
\mathbf{N}^{200} \\
\mathbf{N}_{200}\end{array}$ & $\begin{array}{l}30 \\
30 \\
50 \\
\mathbf{N} \\
70\end{array}$ & $\begin{array}{c}\mathbf{N} \\
200 \\
200 \\
500 \\
\mathbf{N}\end{array}$ & $\begin{array}{r}>20 \\
>20 \\
>20 \\
15 \\
15\end{array}$ & $\begin{array}{l}\text { Do. } \\
\text { Contact Metamorphased argillite. } \\
\text { Do. } \\
\text { Conglomerate. } \\
\text { Altered diorite dike. }\end{array}$ \\
\hline $\begin{array}{l}\mathbf{B} \\
\mathbf{C} \\
\mathbf{D} \\
\mathbf{E} \\
\mathbf{F}\end{array}$ & $\begin{array}{r}\text { ACL } 010 \\
011 \\
012 \\
013 \\
014\end{array}$ & $\begin{array}{r}296 \mathbf{A} \\
\mathbf{B} \\
\mathbf{C} \\
\mathbf{D} \\
\mathbf{E}\end{array}$ & $\begin{array}{l}\mathbf{L} \\
\mathbf{L} \\
\mathbf{N} \\
\mathbf{L} \\
\mathbf{3}\end{array}$ & $\begin{array}{r}\mathbf{N} \\
200 \\
N^{\mathbf{2}} \\
200 \\
>10,000\end{array}$ & $\begin{array}{l}\mathbf{N} \\
\mathbf{N} \\
\mathbf{0 2} \\
\mathbf{N} \\
27.3\end{array}$ & $\begin{array}{r}\mathbf{N} \\
\mathbf{N} \\
\mathbf{N} \\
\mathbf{3 0 0}\end{array}$ & $\begin{array}{r}\mathbf{N} \\
\mathbf{N} \\
5 \\
10 \\
700\end{array}$ & $\begin{array}{r}100 \\
200 \\
20 \\
50 \\
500\end{array}$ & $\begin{array}{l}5 \\
5 \\
N \\
5 \\
N\end{array}$ & $\begin{array}{r}20 \\
5 \\
30 \\
50 \\
30\end{array}$ & $\begin{array}{l}20 \\
10 \\
10 \\
10 \\
20\end{array}$ & $\begin{array}{l}\mathbf{N} \\
\mathbf{N} \\
\mathbf{N} \\
\mathbf{N} \\
200\end{array}$ & $\begin{array}{c}20 \\
100 \\
\mathbf{N} \\
\mathbf{N}\end{array}$ & $\begin{array}{r}\mathbf{N} \\
200 \\
\mathbf{N} \\
\mathbf{N} \\
\mathbf{N}\end{array}$ & $\begin{array}{r}10 \\
15 \\
2 \\
5 \\
15\end{array}$ & $\begin{array}{l}\text { Contact Metamorphased argillite. } \\
\text { Do. } \\
\text { Contact metamorphased greywacke } \\
\text { Arsenopyrite vein. }\end{array}$ \\
\hline \multicolumn{2}{|c|}{$\begin{array}{l}\text { Limits of } \\
\text { determination }\end{array}$} & $\ldots+\cdots+\cdots+\cdots$ & 0.5 & 200 & 0.02 & 10 & 5 & 5 & 5 & 2 & 10 & 100 & 10 & 200 & 0.05 & \\
\hline
\end{tabular}


occurrences of mineralized rocks, as at sample localities $6-8 \mathrm{~A}, 10$, and 11A. Partial results of analyses from the prospects and other mineralized locales are in figure $6 A$ and in table 12.

The Eagle prospect, or Northern Light group (Capps, 1919 , p. 224), is on the east side of Costello Creek south of the Dunkle coal mine. The prospect is on a set of northeastward-striking veins [which are] subparallel to and about 400 feet east of the Lucrata segment of the Upper Chulitna fault. The veins are a few inches to 4 feet wide and contain sulfide-rich masses as much as $\mathbf{1}$ foot in diameter. Arsenopyrite is the most abundant sulfide. One vein can be followed 700 feet from Costello Creek northeastward (fig. 6A) to two prospect pits; it is inferred that it continues on the wall of a serpentinite body for about another 1,000 feet. In Costello Creek a 62-foot-long adit, artly a drift and partly a crosscut, was driven on subparallel vein fissures of the vein set. Samples of mineralized material that were collected near the Eagle adit and prospect pits contain a trace to more than $1 \mathrm{oz}$ gold per ton and from slightly more than $1 \mathrm{oz}$ to $15 \mathrm{oz}$ silver per ton. Ross (1933a) reported assays of $0.2-2.10 \mathrm{oz}$ gold per ton and estimated about 12,000 tons of $\$ 5-10$ rock. The tonnage estimate appears to be minimal, as Ross traced the vein for only about 300 feet.

The Lucrata prospect is in the north-northeasttrending Lucrata segment of the Upper Chulitna fault zone. According to Harry Townsend (unpul. data, 1925), the deposit consists of sulfide-rich pods in the fault zone; the largest pod measures about 4 by 5 feet. A pod about 3 by 3 feet assayed 1.26 oz gold per ton, $3.8 \mathrm{oz}$ silver per ton and 21.25 percent arsenic. Because the Lucrata segment is pyritized and is weakly auriferous at localities $1 \mathrm{~A}$ and $5 \mathrm{~A}$, the shear zone should be prospected further.

At the Liberty prospect, weakly auriferous material $(14 \mathrm{~A}, 15 \mathrm{~A}-\mathrm{C})$ is found in northeast- and northwestoriented vein sets.

At sites $10 \mathrm{~A}$ and $11 \mathrm{~A}$ chalcopyrite or pyrrhotite is disseminated in basalt and gabbro. Weakly sulfidized rock is exposed on a roadcut leading to the Dunkle mine (6-8A); a small vein contained a trace of gold and a 200 -foot-long (7A) chip sample showed trace amounts of $\mathrm{Ag}, \mathrm{As}$, and $\mathrm{Bi}$.

\section{GOLDEN ZONE AREA}

The Golden Zone area, as defined here, extends south from the West Fork of Chulitna Creek to near Long Creek and is nearly centered in the Golden Zone mine (pl. 2). The area contains many kinds of metallic minerals, and in the vicinity of the Golden Zone mine and in the central part of the Bryn Mawr fault, it is strongly mineralized. The main known prospects and occurrences include the Riverside, Lookout Mountain, Copper King, and Long Creek; a mine, the Golden Zone; and nearby veins such as the East, Little, Mayflower, and Lindfors.

\section{GEOLOGIC SETTING}

The Golden Zone area is underlain by layered rocks of pre-Permian, Permian(?), and Triassic age that have been folded, complexly faulted, locally altered and intruded by rocks ranging in composition from ultramafic to granite of possible Tertiary age (pl. 2). Although the area has been mapped in much greater detail than the rest of the district, the geologic relations have been only partly determined because the rocks are only poorly to moderately well exposed.

Argillite and interlayered argillite-graywacke of prePermian age crop out in the eastern part of the area and in scattered parts of the area west of the Upper Chulitna fault and east of the Bryn Mawr fault. The pre-Permian rocks west of the Upper Chulitna fault are generally well bedded; near faults, and east of the Upper Chulitna fault, the rocks are strongly cleaved and bedding is generally not recognizable.

At various places, unconformably overlying the prePermian rocks are a dominant unit of red siltstone, conglomerate or breccia, and minor units of basalt and crystal tuff. In most places the siltstone and conglomerate unit has not been subdivided in mapping. Locally, however, the siltstone and conglomerate were subdivided as shown on plate 2 , and in the faultbounded slice that includes the Golden Zone deposit on plate 2. The coarse clastic rocks of the unit are lithologically diverse. East of the Golden Zone, the main clasts are angular red chert and siltstone, 1-2 inches wide, set in a porous matrix. In Long Creek and on a rounded knob just south of Long Creek in the southwestern map area (pl. 2), a conglomerate contains round boulders as much as 2 feet in diameter in a tuffaceous matrix. Both of these rocks, the angular clast conglomerate and tuffaceous conglomerate, are stratified rocks; in contrast, angular clast conglomerate or breccia exposed about 2,000 feet southwest of the Golden Zone is nonstratified, is completely surrounded by argillite, and may be an agglomerate or volcanic breccia emplaced in the argillite.

A rock unit, west of the dominant red-bed unit near the Golden Zone mine, is faulted against the red-bed unit and grades westward from argillite-graywacke into calcareous argillite and sandy limestone. These rocks are believed to be overturned and to be correlative with a limestone-argillite sequence that normally overlies the red beds. The western part of the Golden Zone area, in the Blind Creek shear zone, is composed of slices of red beds, limestone, and argillite. 
TABLE 12.-Analyses of rock samples from other prospects and occurrences in the Silver King area

[Analysts: E. E. Martinez, $R$. L. Miller, A. $L$. Meier. Analyses, unless noted, are semiquantitative spectrographic and are reported in the series $0.1,0.15,0.2,0.3,0.5,0.7,1.0,1.5$, and so on. $N=$ not
detected; $L=$ detected but below limit of determination; $>=$ greater than. Results are given in parts per million except Fe, which is given in percent]

\begin{tabular}{|c|c|c|c|c|c|c|c|c|c|c|c|c|c|c|c|c|}
\hline $\begin{array}{l}\text { ample } \\
\text { No. }\end{array}$ & $\begin{array}{l}\text { Lab. } \\
\text { No. }\end{array}$ & $\begin{array}{c}\text { Field } \\
\text { No. }\end{array}$ & Ag & As & $\mathbf{A} \mathbf{u}^{1}$ & $\mathbf{B i}$ & Co & $\mathrm{Cu}$ & Mo & $\mathrm{Ni}$ & $\mathbf{P b}$ & $\mathbf{S b}$ & Sn & $\mathbf{z}_{\mathbf{n}}$ & $\mathrm{Fe}$ & Host rock \\
\hline $\begin{array}{l}\mathrm{A} \\
2 \mathrm{~A} \\
3 \mathrm{~A} \\
4 \mathrm{~A} \\
\mathbf{5 A}\end{array}$ & $\begin{array}{r}\text { AGJ } 603 \\
604 \\
601 \\
602 \\
\text { ACK } 009\end{array}$ & $\begin{array}{r}\text { SK } 10 \\
11 \\
7 \\
8 \\
67 \mathrm{ACx} 135\end{array}$ & $\begin{array}{c}5 \\
N^{.7} \\
500 \\
2\end{array}$ & $\begin{array}{r}500 \\
300 \\
>10,000 \\
700\end{array}$ & $\begin{array}{l}0.1 \\
.02 \\
\mathbf{N}^{\circ} \\
6.6 \\
.1\end{array}$ & $\begin{array}{l}\mathrm{N}^{30} \\
\mathrm{~N}^{100} \\
\mathrm{~L}\end{array}$ & $\begin{array}{c}10 \\
150 \\
100 \\
L \\
30\end{array}$ & $\begin{array}{r}500 \\
30 \\
100 \\
2,000 \\
500\end{array}$ & $\begin{array}{l}30 \\
\mathbf{N} \\
\mathbf{N} \\
\mathbf{N} \\
\mathbf{N}\end{array}$ & $\begin{array}{r}50 \\
5,000 \\
5,000 \\
10 \\
70\end{array}$ & $\begin{array}{r}50 \\
10 \\
L, 000 \\
15\end{array}$ & $\begin{array}{l}\mathbf{N} \\
\mathbf{N} \\
\mathbf{N} \\
3,000 \\
\mathrm{~N}\end{array}$ & $\begin{array}{l}30 \\
\mathrm{~N} \\
\mathrm{~L} \\
\mathrm{~N} \\
\mathbf{2 0}\end{array}$ & $\begin{array}{c}\mathbf{N} \\
\stackrel{N}{N} \\
10,000 \\
N\end{array}$ & $\begin{array}{c}10 \\
15 \\
7 \\
10 \\
7\end{array}$ & $\begin{array}{l}\text { Lucrata segment, Upper Chulitna fault. } \\
\text { Serpentinite on wall of Eagle Vein. } \\
\text { Do. } \\
\text { Eagle Vein. Prospect pit. } \\
\text { Lucrata segment, upper Chulitna fault. }\end{array}$ \\
\hline $\begin{array}{r}6 \mathrm{~A} \\
7 \mathrm{~A} \\
8 \mathrm{~A} \\
9 \mathrm{~A} \\
10 \mathrm{~A}\end{array}$ & $\begin{array}{r}\text { AGJ } 605 \\
606 \\
607 \\
\text { ACK } 010 \\
\text { AGJ } 614\end{array}$ & $\begin{array}{r}\text { SK } 18 \\
19 \\
20 \\
67 \mathrm{ACx} 136 \\
\text { SK } 18\end{array}$ & $\begin{array}{c}2 \\
\mathrm{~L} \\
3 \\
100 \\
\quad .2\end{array}$ & $\begin{array}{r}\mathrm{L}_{200} \\
>10,000 \\
>10,000 \\
\mathrm{~N}\end{array}$ & $\begin{array}{l}\mathrm{N} \\
\mathrm{N} \\
50 \\
.4\end{array}$ & $\begin{array}{c}L \\
L \\
20 \\
1,000 \\
15\end{array}$ & $\begin{array}{r}10 \\
15 \\
20 \\
300 \\
15\end{array}$ & $\begin{array}{r}70 \\
150 \\
1,500 \\
700 \\
1,000\end{array}$ & $\begin{array}{l}\mathbf{L} \\
\mathbf{7} \\
\mathbf{N} \\
\mathbf{N} \\
\mathbf{N}\end{array}$ & $\begin{array}{r}30 \\
70 \\
50 \\
30 \\
150\end{array}$ & $\begin{array}{l}200 \\
\mathrm{~L} \\
\mathrm{~N} \\
\mathbf{7 0 0} \\
\mathrm{L}\end{array}$ & 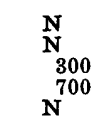 & $\begin{array}{l}\mathbf{N} \\
\mathbf{N} \\
\mathbf{N} \\
\mathbf{N} \\
\mathbf{L}\end{array}$ & $\begin{array}{l}700 \\
\mathbf{N} \\
\mathbf{L} \\
\mathbf{N}\end{array}$ & $\begin{array}{l}7 \\
10 \\
20 \\
20 \\
15\end{array}$ & $\begin{array}{l}\text { Roadcut. Porphyry dike. } \\
\text { Roadcut. } 200 \text {-foot chip sample. } \\
\text { Roadcut. } 1-3 \text { inch vein. } \\
\text { Lucrata vein. } \\
\text { Gabbro-basalt. Disseminated pyrrhotite-chalcopyrite. }\end{array}$ \\
\hline $\begin{array}{r}11 \mathrm{~A} \\
12 \mathrm{~A} \\
13 \mathrm{~A} \\
\mathbf{B} \\
\mathbf{C}\end{array}$ & $\begin{array}{r}\text { ACK } 011 \\
022 \\
023 \\
024 \\
025\end{array}$ & 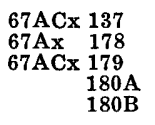 & $\begin{array}{c}.5 \\
1.5 \\
50 \\
100 \\
50\end{array}$ & $\begin{array}{r}500 \\
N \\
3,000 \\
>10,000 \\
1,500\end{array}$ & $\begin{array}{r}.3 \\
.4 \\
2.2 \\
15.9 \\
.9\end{array}$ & $\begin{array}{l}\mathrm{N}_{20}^{15} \\
100 \\
\mathrm{~N}^{-}\end{array}$ & $\begin{array}{r}300 \\
20 \\
\mathbf{N} \\
15 \\
10\end{array}$ & $\begin{array}{r}200 \\
100 \\
150 \\
3,000 \\
150\end{array}$ & $\begin{array}{l}\mathbf{N} \\
\mathbf{N} \\
\mathbf{N} \\
\mathbf{N} \\
\mathbf{N}\end{array}$ & $\begin{array}{r}150 \\
100 \\
10 \\
20 \\
7\end{array}$ & $\begin{array}{l}\mathrm{L} \\
10 \\
300 \\
500 \\
300\end{array}$ & $\begin{array}{l}\mathrm{L} \\
\mathrm{N} \\
500 \\
3,000 \\
700\end{array}$ & $\begin{array}{l}10 \\
\mathbf{N} \\
\mathbf{N} \\
\mathbf{N} \\
\mathbf{5 0}\end{array}$ & $\begin{array}{l}\mathbf{N} \\
\mathbf{N} \\
\mathbf{L} \\
\mathbf{3 0 0} \\
\mathbf{N}\end{array}$ & $\begin{array}{c}10 \\
7 \\
1.5 \\
15 \\
1.5\end{array}$ & $\begin{array}{l}\text { Gabbro-basalt. Disseminated pyrrhotite. } \\
\text { Do. } \\
\text { Eagle prospect. Arsenopyrite-bearing greenstone. } \\
\text { Do. } \\
\text { Do. }\end{array}$ \\
\hline $\begin{array}{r}\mathrm{D} \\
14 \mathrm{~A} \\
15 \mathrm{~A} \\
\mathbf{B} \\
\mathbf{C}\end{array}$ & $\begin{array}{r}033 \\
\text { AGJ } 608 \\
609 \\
610 \\
\text { ACK } 019\end{array}$ & $\begin{array}{r}181 \\
\mathrm{SK}_{21} \\
22 \mathrm{~A} \\
22 \mathrm{~B} \\
67 \mathrm{Cx} \quad 166\end{array}$ & $\begin{array}{c}300 \\
10 \\
1.5 \\
1.5 \\
3\end{array}$ & $\begin{array}{l}>10,000 \\
>10,000 \\
>10,000 \\
\stackrel{N}{N}\end{array}$ & $\begin{array}{c}38 \\
.2 \\
.6 \\
1.7 \\
.08\end{array}$ & $\begin{array}{r}30 \\
\mathrm{~L}^{20} \\
\mathrm{~N}^{70}\end{array}$ & $\begin{array}{r}15 \\
100 \\
N \\
200 \\
20\end{array}$ & $\begin{array}{r}700 \\
1,000 \\
500 \\
150 \\
700\end{array}$ & $\begin{array}{l}\mathbf{N} \\
\mathbf{2 0} \\
\mathbf{3 0} \\
\mathbf{3 0} \\
\mathbf{N}\end{array}$ & $\begin{array}{r}200 \\
50 \\
50 \\
7 \\
50\end{array}$ & $\begin{array}{r}1,500 \\
100 \\
\mathrm{~L} \\
1,000 \\
15\end{array}$ & $\begin{array}{r}7,000 \\
500 \\
1,500 \\
700 \\
150\end{array}$ & $\begin{array}{l}\mathbf{N} \\
\mathbf{N} \\
\mathbf{N} \\
\mathbf{N} \\
\mathbf{N}\end{array}$ & $\begin{array}{l}1,500 \\
\stackrel{N}{N} \\
\mathbf{N} \\
\mathbf{N}\end{array}$ & $\begin{array}{r}7 \\
5 \\
5 \\
20 \\
10\end{array}$ & $\begin{array}{l}\text { Do. } \\
\text { Liberty prospect. Arsenopyrite vein. } \\
\text { Arsenopyrite-bearing hornfelsed argillite. } \\
\text { Arsenopyrite vein. } \\
\text { Gossan. }\end{array}$ \\
\hline $\begin{array}{r}16 \mathrm{~A} \\
17 \mathrm{~A} \\
18 \mathrm{~A} \\
\mathbf{B} \\
\mathbf{C}\end{array}$ & $\begin{array}{r}\text { AGJ } 611 \\
612 \\
\text { ACL } 015 \\
016 \\
017\end{array}$ & $\begin{array}{r}\text { SK } 23 \\
24 \\
67 \mathrm{ACx} 297 \\
297 \mathrm{~A} \\
297 \mathrm{~B}\end{array}$ & $\begin{array}{c}\mathbf{N} \\
5 \\
\mathbf{L} \\
10 \\
7\end{array}$ & $\begin{array}{r}\mathrm{L}^{300} \\
200 \\
500 \\
700\end{array}$ & $\begin{array}{l}\mathrm{N} \\
\mathrm{N} \\
\mathrm{N} \\
.04 \\
.2\end{array}$ & $\begin{array}{l}\mathrm{L} \\
\mathrm{N} \\
\mathrm{N} \\
\mathrm{N} \\
15\end{array}$ & $\begin{array}{l}20 \\
50 \\
5 \\
15 \\
70\end{array}$ & $\begin{array}{r}200 \\
50 \\
50 \\
1,500 \\
1,000\end{array}$ & $\begin{array}{r}\mathbf{N} \\
\mathbf{L} \\
\mathbf{N} \\
10 \\
5\end{array}$ & $\begin{array}{r}100 \\
300 \\
50 \\
30 \\
\mathbf{5 0}\end{array}$ & $\begin{array}{l}\text { L } \\
15 \\
10 \\
10 \\
15\end{array}$ & $\begin{array}{l}\mathbf{L} \\
\mathbf{N} \\
\mathbf{N} \\
\mathbf{N} \\
\mathbf{N}\end{array}$ & $\begin{array}{l}N \\
N \\
20 \\
50 \\
15\end{array}$ & $\begin{array}{l}\mathbf{N} \\
\mathbf{N} \\
\mathbf{N} \\
200 \\
\mathbf{N}\end{array}$ & $\begin{array}{r}10 \\
15 \\
2 \\
10 \\
7\end{array}$ & $\begin{array}{l}\text { Mafic rock. } \\
\text { Porphyry. } \\
\text { Tactite: magnatite, epidote, garnet, and actinolite. } \\
\text { Do. } \\
\text { Contact metamorphosed argillite. }\end{array}$ \\
\hline $\begin{array}{r}\mathrm{D} \\
19 \mathrm{~A} \\
20 \mathrm{~A} \\
\end{array}$ & $\begin{array}{l}018 \\
019 \\
020 \\
\end{array}$ & $\begin{array}{l}297 \mathrm{C} \\
298 \\
299\end{array}$ & $\begin{array}{r}N \\
10 \\
7\end{array}$ & $\begin{array}{r}500 \\
7,000 \\
10,000\end{array}$ & $\begin{array}{l}.02 \\
.5\end{array}$ & $\begin{array}{l}10 \\
10 \\
10\end{array}$ & $\begin{array}{r}10 \\
7 \\
300\end{array}$ & $\begin{array}{r}150 \\
200 \\
2,000\end{array}$ & $\begin{array}{l}\mathbf{N} \\
\mathbf{5 0}\end{array}$ & $\begin{array}{l}30 \\
30 \\
30\end{array}$ & $\begin{array}{r}10 \\
300 \\
20\end{array}$ & $\begin{aligned} \mathrm{N} \\
>10,000 \\
200\end{aligned}$ & $\begin{array}{l}\mathbf{N} \\
\mathbf{N} \\
\mathbf{N}\end{array}$ & $\underset{1,500}{N}$ & $\begin{array}{l}3 \\
7 \\
1.5\end{array}$ & $\begin{array}{l}\text { Quartz diorite porphyry. } \\
\text { Stibnite-quartz vein material. } \\
\text { Arsenopyrite, sparse stibnite, vein. }\end{array}$ \\
\hline $\begin{array}{l}\text { Limits } \\
\text { deterr }\end{array}$ & $\begin{array}{l}\text { of } \\
\text { mination }\end{array}$ & 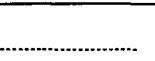 & 0.5 & 200 & 0.02 & 10 & 5 & 5 & 5 & 2 & 10 & 100 & 10 & 200 & 0.05 & \\
\hline
\end{tabular}

${ }^{1}$ Atomic absorption. 
The sedimentary and volcanic rocks of the Golden Zone area are locally strongly altered and can be correlated only by tracing them into less altered facies. The rocks that are bounded by the Bryn Mawr fault and a subparallel fault to the west, near the Golden Zone, consist of sulfidized and argillic altered palegreen siltstone and dense, calcitic, almost white conglomerate or breccia with sparse pyrrhotite and arsenopyrite. These rocks project both northeast and southwest into interlayered red siltstone and conglomerate or breccia and apparently are their altered equivalents.

Intruded into the layered rocks are serpentinite, basalt and gabbro, and porphyritic rocks of intermediate to granitic composition. Diorite porphyry forms an elongate dike in the northwest part of the map area (pl. 2), and quartz diorite porphyry forms the Golden Zone stock and a series of dikes of northeast strike. The main masses of granitic rocks, chiefly quartz porphyry and felsite, are at the Lookout Mountain occurrence and the Copper King prospect.

Porphyritic rocks of both intermediate and granite composition and mafic or ultramafic rocks have been weakly mineralized in many places. As shown by analyses, dikes of the area contain detectable and locally anomalous amounts of elements such as gold, copper, lead, bismuth, arsenic, and zinc (table 13 and pl. 2).

The major faults of the area strike north-northeast; they are, from east to west (pl. 2) : (1) Upper Chulitna fault, (2) Bryn Mawr fault, (3) a subparallel fault 1,000-3,000 feet west of the Bryn Mawr fault, and (4) branches of the Blind Creek fault. Although the trace of the faults on the surface suggests that the Upper Chulitna fault and Bryn Mawr faults could have general westerly dips, nearly vertical to steep eastward dips are observed in their rare exposures as in Bryn Mawr Creek. By inference from two outcrops in the northwest part of the area, the Bryn Mawr and its associated fault to the west may be cut off to the north by a fault of northeast strike (pl. 2). About 2 miles east of the Golden Zone mine, a fault of northwest strike displaces the red-bed-argillite contact and, although the critical fault junction is not actually exposed, the northwest-striking fault is inferred to offset the Upper Chulitna fault.

The main mineralized vein fissues in the Golden Zone area belong to the same set as the Bryn Mawr fault, which is locally mineralized. The vein fissues include the Lindfors, Little, East, and Mayflower veins, which are shown on plate 2 .

\section{GOLDEN ZONE MINE}

The Golden Zone mine is the most important mine of the district. Besides gold, the deposit contains significant amounts of copper and silver and trace amounts of rare elements, including antimony, bismuth, cadmium, molybdenum, and tin.

Discovery of placer gold in Bryn Mawr Creek in about 1907 led to the discovery of the outcrop of the Golden Zone deposit and to extensive prospecting and staking in the area in 1909. A short adit (100-foot level) was driven into the Golden Zone breccia pipe in 1915, but little additional work was done until 1934, when the American Smelting and Refining Co. optioned the property and contracted with the owners to drive a lower sampling adit, the start of the present 200 -foot level. According to the late Lon Wells, former owner, and Ralph Tuck, then of the U.S. Geological Survey (unpub. data, 1934), the adit was driven for 347 feet. It entered mineralized rock at about 200 feet and was still in mineralized rock at the face. Though a 50-foot mineralized interval assayed about $\$ 8$ per ton, the option was dropped. At about this time, W. E. Dunkle bought a half interest in the property and, during or before 1937, extended the 200-foot level on through the deposit. In 1937 the property was again optioned, this time by Anaconda Mining Co., which carried on a fairly extensive diamond drilling program before the option was dropped. At that time the prospect reverted to a group led by Dunkle, who felt that the explora-

TABLE 13.-Analyses of dike rocks from the Golden Zone mine area

[Analysts: E. E. Martinez, R. L. Miller, A. L. Meier, Analyses, unless noted, are semiquantitative spectrographic and are reported in the series 0.1, 0.15, $0.2,0.3,0.5,0.7,1.0,1.5$, and so on. $\mathbf{N}=$ not detected; $\mathbf{L}=$ detected but below limit of determination; .... not looked for; $>=$ greater than. Results are given in parts per million except $\mathrm{Fe}$ and $\mathrm{Ti}$, which are given in percent]

\begin{tabular}{|c|c|c|c|c|c|c|c|c|c|c|c|c|c|c|c|c|c|c|}
\hline $\begin{array}{l}\text { Sample } \\
\text { No. }\end{array}$ & $\begin{array}{l}\text { Lab } \\
\text { No. }\end{array}$ & & $\begin{array}{l}\text { Fiel } \\
\text { No }\end{array}$ & & Ag & As & $\mathrm{Au}^{1}$ & $\mathbf{B i}$ & Cd & $\mathbf{C u}$ & Mo & $\mathbf{P b}$ & $\mathbf{S b}$ & Sn & $\mathbf{Z n}$ & $\mathrm{Fe}$ & $\mathbf{T i}$ & Host rock \\
\hline $\begin{array}{r}\text { D1 } \\
2 \\
3 \\
4 \\
5\end{array}$ & $\begin{array}{l}\text { ACF } \\
\text { D101 } \\
\text { ACF }\end{array}$ & $\begin{array}{l}067 \\
858 \\
058 \\
059 \\
002\end{array}$ & $\begin{array}{l}\text { 68AHx } \\
\text { 67AHx }\end{array}$ & $\begin{array}{l}192 \mathrm{~A} \\
253 \\
135 \mathrm{~B} \\
144 \\
107\end{array}$ & $\begin{array}{c}N \\
N \\
0.7 \\
.5 \\
\mathbf{L}\end{array}$ & $\begin{array}{l}\mathbf{N} \\
\mathbf{N} \\
\mathbf{L} \\
\mathbf{N} \\
\mathbf{N}\end{array}$ & $\begin{array}{l}\mathbf{N} \\
\mathbf{N} \\
\mathbf{N} \\
\mathbf{N} \\
\mathbf{N}\end{array}$ & $\begin{array}{l}\mathbf{L} \\
\mathbf{N} \\
\mathbf{N} \\
\mathbf{N} \\
\mathbf{N}\end{array}$ & $\begin{array}{l}\mathbf{N} \\
\mathbf{N} \\
\mathbf{N} \\
\mathbf{N} \\
\mathbf{N}\end{array}$ & $\begin{array}{r}20 \\
30 \\
5 \\
20 \\
15\end{array}$ & $\begin{array}{l}\mathbf{N} \\
\mathbf{N} \\
\mathbf{L} \\
\mathbf{N} \\
\mathbf{N}\end{array}$ & $\begin{array}{r}10 \\
10 \\
50 \\
70 \\
100\end{array}$ & $\begin{array}{l}\mathbf{N} \\
\mathbf{N} \\
\mathbf{N} \\
\mathbf{N} \\
\mathbf{N}\end{array}$ & $\begin{array}{l}\mathbf{L} \\
\mathbf{N} \\
\mathbf{L} \\
\mathbf{N} \\
\mathbf{N}\end{array}$ & $\begin{array}{l}\mathbf{N} \\
\mathbf{N} \\
\mathbf{N} \\
\mathbf{L} \\
\mathbf{N}\end{array}$ & $\begin{array}{r}3 \\
\cdots \\
2 \\
3 \\
5\end{array}$ & $\begin{array}{l}0.3 \\
. .3 \\
.3 \\
.2 \\
.3\end{array}$ & $\begin{array}{l}\text { Quartz diorite. } \\
\text { Biotite diorite. } \\
\text { Felsic porphyry. } \\
\text { Quartz diorite. } \\
\text { Felsic porphyry. }\end{array}$ \\
\hline $\begin{array}{l}6 \\
7 \\
8 \\
4 \mathrm{~A} \\
3 \mathrm{~A}\end{array}$ & $\begin{array}{l}\text { ACE } \\
\text { AGJ } \\
\text { ACF }\end{array}$ & $\begin{array}{l}002 \\
616 \\
941 \\
014 \\
013\end{array}$ & $\begin{array}{r}\text { 68ACS } \\
\mathrm{Hx}\end{array}$ & $\begin{array}{l}107 \\
229 \\
868 \mathrm{~B} \\
145 \\
137\end{array}$ & $\begin{array}{l}\mathrm{L} \\
\mathrm{N} \\
\dot{\mathrm{L}}^{7} \\
1.5\end{array}$ & $\begin{array}{l}\mathbf{N} \\
\mathbf{N} \\
\mathbf{N} \\
\mathbf{N} \\
\mathbf{L}\end{array}$ & $\begin{array}{l}\mathbf{N} \\
0.02 \\
\mathbf{N} \\
\mathbf{N} \\
.06\end{array}$ & $\begin{array}{l}\mathbf{N} \\
\mathbf{N} \\
\mathbf{N} \\
\mathbf{N} \\
\mathbf{N}\end{array}$ & $\begin{array}{r}\mathbf{N} \\
\mathbf{N} \\
\mathbf{N} \\
\mathbf{N} \\
20\end{array}$ & $\begin{array}{l}15 \\
20 \\
20 \\
30 \\
30\end{array}$ & $\begin{array}{l}\mathbf{N} \\
\mathbf{5} \\
\mathbf{L} \\
\mathbf{N} \\
\mathbf{N}\end{array}$ & $\begin{array}{r}100 \\
30 \\
1,500 \\
30 \\
70\end{array}$ & $\begin{array}{l}\mathbf{N} \\
\mathbf{N} \\
300 \\
\mathbf{N} \\
\mathbf{N}\end{array}$ & $\begin{array}{l}\mathbf{N} \\
10 \\
\mathbf{5 0} \\
\mathbf{N} \\
\mathbf{2 0}\end{array}$ & $\begin{array}{c}\mathbf{N} \\
\mathbf{N} \\
\mathbf{7 0 0} \\
\mathbf{N} \\
\mathbf{3 0 0}\end{array}$ & $\begin{array}{l}\mathbf{5} \\
\mathbf{5} \\
\mathbf{3} \\
\mathbf{3} \\
\mathbf{3}\end{array}$ & $\begin{array}{l}.3 \\
.3 \\
.2 \\
.15 \\
1.5\end{array}$ & $\begin{array}{l}\text { Do. } \\
\text { Biotite diorite. } \\
\text { Quartz porphyry. } \\
\text { Rhyolite. } \\
\text { Basalt. }\end{array}$ \\
\hline \multicolumn{5}{|c|}{$\begin{array}{l}\text { Limits of } \\
\text { determination .. }\end{array}$} & 0.5 & 200 & 0.02 & 10 & 5 & 5 & 5 & 2 & 10 & 10 & 200 & 0.05 & 0.001 & \\
\hline
\end{tabular}

${ }^{1}$ Atomic absorption. 
tion had showed enough to warrant the construction of a mill, to drive stoping drifts on the two working levels, and to start a crosscut adit to cut the deposit about 500 feet below the surface. The crosscut or haulage adit never reached the ore body, but an ore pass raise was driven, allowing partly underground transportation of the ore from the working adits to the mill. Dunkle's original plans called for a still deeper $21 / 2$ mile tunnel driven from the Riverside group of claims, but this project was never started.

Development of the property was rapid, and the mine came into production in 1941. By 1942, however, the mine was closed at least partly because of War Production Board Order L-208, which closed most gold mines. During 1941-1942 the mine shipped 869 tons of bulk flotation concentrates containing 1,581 ounces gold, 8,617 ounces silver, 21 tons copper, and about 3,000 pounds lead. Zinc, if recovered, was not reported. According to records held by Rea Beckwith (oral commun., 1967), the concentrates were produced from 1,730 tons of crude ore, indicating an average grade of $0.91 \mathrm{oz}$ per ton gold, about $5 \mathrm{oz}$ per ton silver, and about 1.2 percent copper. This grade is appreciably higher than that indicated by the bulk of the drilling and channel sampling, but it is not unreasonably high, as all the stoping was in the known high-grade part of the deposit. The only high-grade ore was stoped reflected in part pressure from stockholders (F. F. Barnes, unpub. data, 1941). The mine did not reopen after the war, but the U.S. Bureau of Mines drilled one long diamond drill hole through the deposit in 1950 and several short ones near it in 1950 and 1951 (Mulligan and others, 1967). Since that time there has been no activity other than assessment work and surficial mapping and sampling in the district.

The Golden Zone deposit has been explored by two adits, by surface cuts, and by numerous diamond drill holes. Mine workings in approximately correct orientation are shown in figure 7A. The apex of the mineralized body is at approximately 3,645 feet and the so-called 100- and 200-foot levels are at about 3,554 and 3,470 feet, respectively. With the exception of short stoping drifts with raises on bothe the 100 - and 200 -foot levels, the mine workings are crosscuts driven for exploration purposes. A cresscut adit (500-ft level) with its portal at about 3,160-feet altitude stops approximately 1,000 feet short of the deposit.

The Golden Zone deposit is nearly in the center of an irregular and approximately tadpoled-shaped (in plan) stock of biotite quartz diorite porphyry that has maximum dimensions of about 600 by 1,000 feet. Drifts and drill holes show that the stock has vertical contacts (section $A-A^{\prime}, \mathrm{pl} .2$ ). Judged from surface exposures, assay maps (Mulligan and others, 1967), and unpub- lished geological maps, the main part of the mineral deposit is in a breccia pipe about 200 or more feet in diameter. The outer part of the pipe has concentric and almost veinlike masses of breccia that surround the inner shattered rocks (figs. $7 A$ and $7 B$ ). Ore, chiefly arsenopyrite and subordinately chalcopyrite, sphalerite, pyrite, and quartz, fill the extensive open spaces of the breccias and fractures in the shattered rock (fig. 8). Relatively high grade parts of the deposit are in the breccia zone; relatively low grade parts are in the shattered core of the pipe and in an envelope of fractured and altered porphyry that surrounds the pipe. The total extent of mineralized rock in the pipe and halo is in a body about 400 -feet wide.

The grade of the deposit is known locally (figs. $7 A$, $7 B$ ), but the average grade of the mineralized rock in the central part of the pipe and in the envelope around it is undetermined. The average grade could be critical in the exploitation of the deposit. Assays of samples from the well-mineralized breccia zone on the 200 -foot level range from approximately 0.06 to $0.6 \mathrm{oz}$ gold per ton (fig. 7A) and generally show an ounce or more silver per ton. Composited samples from the 200 -foot level that were used by the U.S. Bureau of Mines in a mill test (Mulligan and others, 1967) assayed $0.23 \mathrm{oz}$ gold per ton, $1.25 \mathrm{oz}$ silver per ton, and 0.24 percent copper. The arithmetic mean of 228 samples in the halo outside the well-mineralized zone is $0.04 \mathrm{oz}$ gold per ton, but samples from the core are too few to compute a meaningful average.

Assays of samples from the 100 -foot adit range from a trace in gold to more than $0.40 \mathrm{oz}$ gold per ton, more than 1 percent copper, and 6 oz silver per ton (fig. $7 B$ ). Assays of samples from surface cuts locally exceed $1 \mathrm{oz}$ gold per ton, but in general are comparable to those samples from the two adits, and from the intersections in drill holes down to about 300 feet below the 200 -foot level (Mulligan and others, 1967).

\section{OTHER OCCURRENCES}

Several veins, including the Little and East, are so close to the Golden Zone that it might be feasible to mine them from underground workings driven to develop the Golden Zone deposit.

\section{LITTLE VEIN}

The Little vein is on the south side of Bryn Mawr Creek opposite the Golden Zone workings and is probably cut by the 200 -foot level crosscut of the Golden Zone mine (fig. $7 A$ ). On the surface the Little vein is in porphyry (pl. 2); the vein strikes north-northeast, or approximately parallel to the local southeast contact of the Golden Zone stock. Most workings on the vein 
are caved, but the vein can be projected through old pits and a short caved adit for about 300 feet and toward another vein exposure in Bryn Mawr Creek about 300 feet to the north (sample locality $8 \mathrm{~B}, \mathrm{pl} .2$ ). One sample of scorodite-stained dump material (table 14 , No. 6B) assayed 25 ppm gold, approximately 0.7 oz per ton, a value generally consistent with fire-assay results on six samples reported by Ross (1933a, p. 323) given below:

Assays of sample from Little vein

\begin{tabular}{|c|c|c|c|c|}
\hline $\begin{array}{l}\text { Sample } \\
\text { No. } \\
\text { of Ross } \\
\text { (1933a) }\end{array}$ & $\begin{array}{l}\text { Gold } \\
\text { (oz. per } \\
\text { ton) }\end{array}$ & $\begin{array}{l}\text { Silver } \\
\text { (oz. per } \\
\text { ton) }\end{array}$ & $\begin{array}{c}\text { Arsenic } \\
\text { (percent) }\end{array}$ & Sampler \\
\hline R...grab (dump) & 2.58 & 4.70 & 33.22 & Harry Townsend. \\
\hline S ....1.0 foot & .48 & 2.40 & 23.61 & Do. \\
\hline g ....grab (opencuts) & .86 & 11.60 & 18.10 & J. G. Shephard. \\
\hline $6 \ldots . .3 .0$ feet & .16 & 2.40 & - & C. P. Ross. \\
\hline $7 \ldots . .6$ foot & .99 & 6.60 & - & Do. \\
\hline $8 \ldots . .0$ feet & .36 & 2.40 & 一 & Do. \\
\hline
\end{tabular}

Vein material at sample locality $8 \mathrm{~B}$ was also auriferous (table 14), containing about $1 \mathrm{oz}$ gold per ton.

EAST VEIN

The East vein is exposed in Bryn Mawr Creek and was intersected in the crosscut adit level of the Golden Zone mine (pl. 2). The vein strikes about N. $25^{\circ}$ E., dips $75^{\circ} \mathrm{NW}$, and ranges in width from slightly more than 1 foot to about 3 feet. Sulfides make up as much as 80 percent of the 1 -foot widths of the vein which are exposed in Bryn Mawr Creek. They are, in order of abundance, pyrite, arsenopyrite, sphalerite, galena, and chalcopyrite. The vein in the crosscut adit was reported to be as wide as 8 feet and to contain as much as 1.5 oz gold per ton with some silver and copper (Anchorage Weekly Times, July 20,1939).

A sample rich in arsenopyrite and another rich in galena-sphalerite (table 14, No. 14B) were collected from the East vein in Bryn Mawr Creek. Both samples show considerable gold, more than 1 percent arsenic, and 1 percent or more lead and zinc. The results of analyses of four channel samples taken across about $1 \frac{1}{2}$ foot widths by the U.S. Bureau of Mines (Mulligan and others, 1967) indicate $0.01-0.90 \mathrm{oz}$ per ton gold, 1.2-8.5 oz per ton silver, and as much as 1.8 percent lead and 1.7 percent zinc.

Sulfide-bearing rock also occurs near a short dike about 150-200 feet upstream from the East vein at localities 12 and 13B. Strongly jarositic and pyritic rock that was sampled downstream as locality $15 \mathrm{~B}$ contains $500 \mathrm{ppm}$ of copper but no gold or silver.

\section{MAYFLOWER VEIN}

The Mayflower vein is a set of northeastward-trend- ing veins that are exposed in shallow trenches and opencuts. A shallow shaft near locality $21 \mathrm{~B}$ (pl. 2) on the vein is caved.

The wallrock is calcitized and contact metamorphased volcanic conglomerate with disseminated pyrite and arsenopyrite. A dike of fresh biotite quartz diorite porphyry is partly exposed in the trench system that explores the veins; like the veins, it strikes northnortheast and dips steeply.

The main vein of the lode system ranges in width from a few inches to about 15 feet and can be traced through prospect pits for about 600 feet. Arsenopyrite, chalcopyrite, and pyrite are visible locally, but most vein material is oxidized and composed of limonite.

Results of sampling by the authors (pl. 1, samples 16-22B, table 15), the U.S. Bureau of Mines, and the owner W. H. Greene, indicate very low to moderate values in gold, silver, copper, lead, and zinc. A 5-foot channel sample taken by the Bureau of Mines at about the location of our sample No. B16 (a 15-foot chip sample) shows $0.14 \mathrm{oz}$ per ton gold, $0.25 \mathrm{oz}$ per ton silver, and 0.10 percent copper with trace amounts of lead and zinc. Two samples that were collected by Greene from the now-caved shaft (near locality 21B) and analyzed by the Alaska State Division of Mines and Minerals showed about 10 percent combined base metals (copper, lead, and zinc) and about $3 \mathrm{oz}$ per ton silver with a trace of gold (W. H. Greene, written commun., 1951).

Data on occurrences that are farther away from the Golden Zone than the Little and East veins are summarized below. Analyses of rock samples and streamsediment samples from the mapped area (pl. 2) are given in table 15.

RIVERSIDE

The Riverside prospect mentioned by Ross (1933a) was located by the authors, but the area is overgrown by willows and prospect pits are caved (pl. 2). The deposit was reported by $\mathrm{H}$. Townsend (unpub. data, 1925) to consist of two north-trending steely dipping veins cutting limestone bedrock. Townsend's sketch map of the prospect and the results of his assays are shown in figure 9.

\section{BANNER}

Gold-bearing arsenopyrite veins crop out in and near shallow, largely caved prospect pits south of the Riverside prospect; an old claim identifies the location as Banner No. 5 (locality 2, pl. 2, table 15). Similar arsenopyrite-bearing material is exposed at locality 1 .

\section{LINDFORS}

South of the Golden Zone mine are some very poorly exposed veins in prospect pits and a shallow shaft excavated before 1920 . Other veins can be inferred from 


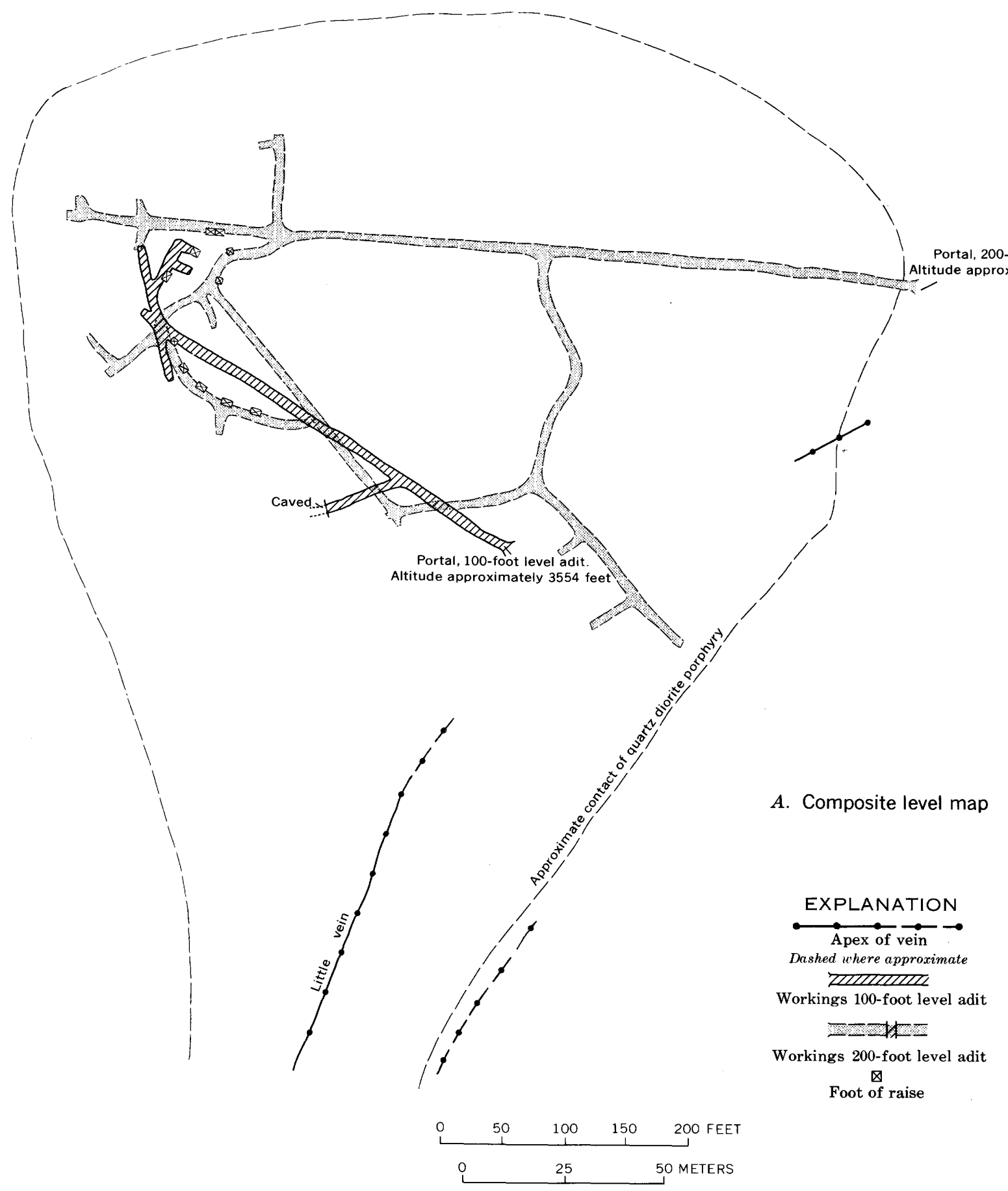

FIGURE 7.-Mine workings at the Golden Zone mine showing assays.

anomalous metal values found in colluvial materials that were collected from shallow trenches in the same general area. The mapped structures include the Lindfors group of veins briefly described by Capps $(1919, \mathrm{p}$. $226)$ and Ross (1933a, p. 321) and possibly the Golden Zone Extension noted by Capps (1919, p. 230).

The veins at the Lindfors prospect strike northeast, dip vary steeply, and form a set parallel to a dike of biotite quartz diorite porphyry. Veins are exposed discontinuously in prospect pits for about 1,000 feet on strike and over a width of at least 100 feet. Individual vein structures of the set range in width from an inch to 1 or 2 feet. Samples from vein exposures or from dump materials which were collected next to shallow prospect pits (loc. 7A, B, C, E, F, and G; pl. 2; and table 16) contain gold in amounts ranging from about 


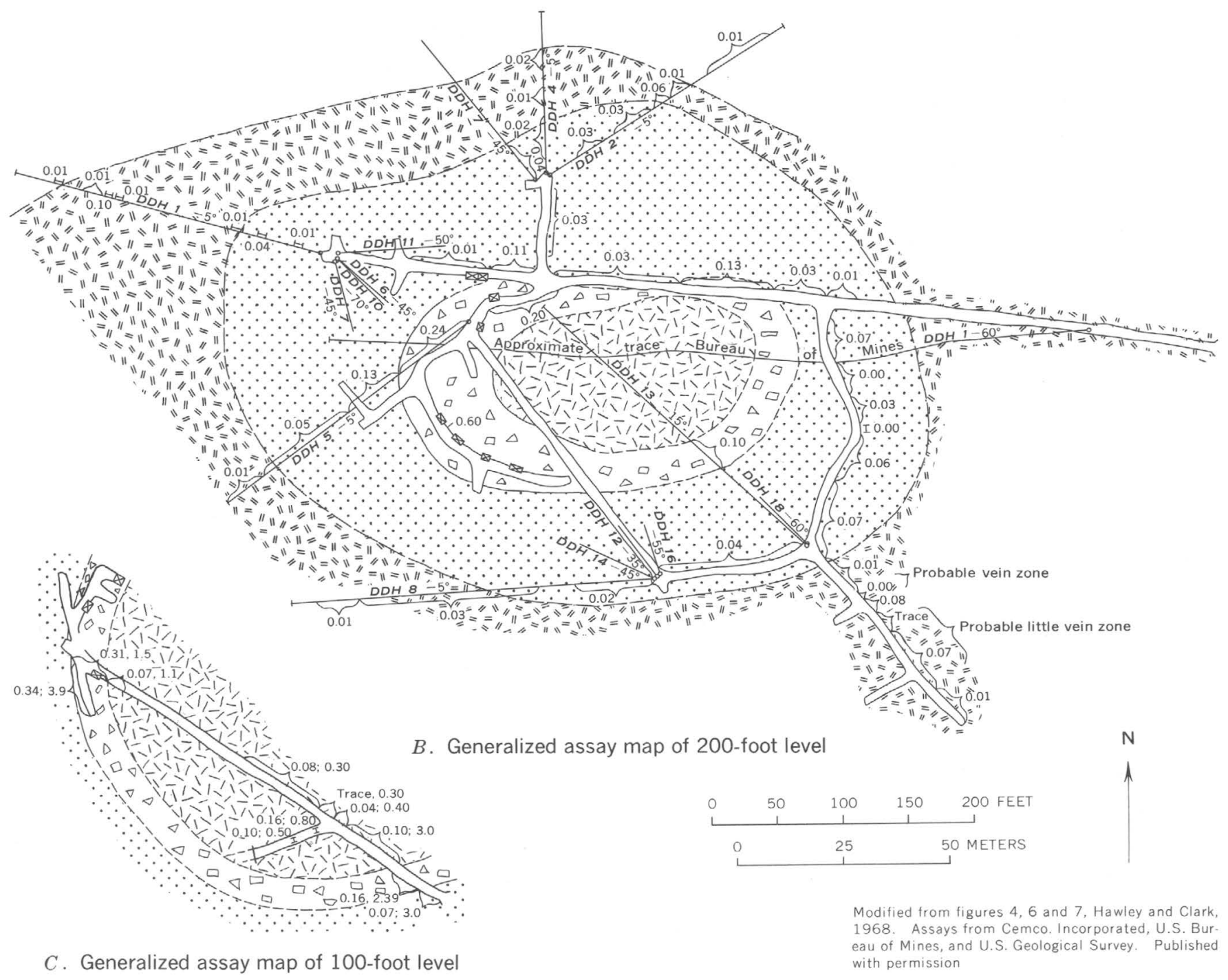

C. Generalized assay map of 100 -foot level

o. Incorporated, U.S. Burwith permission

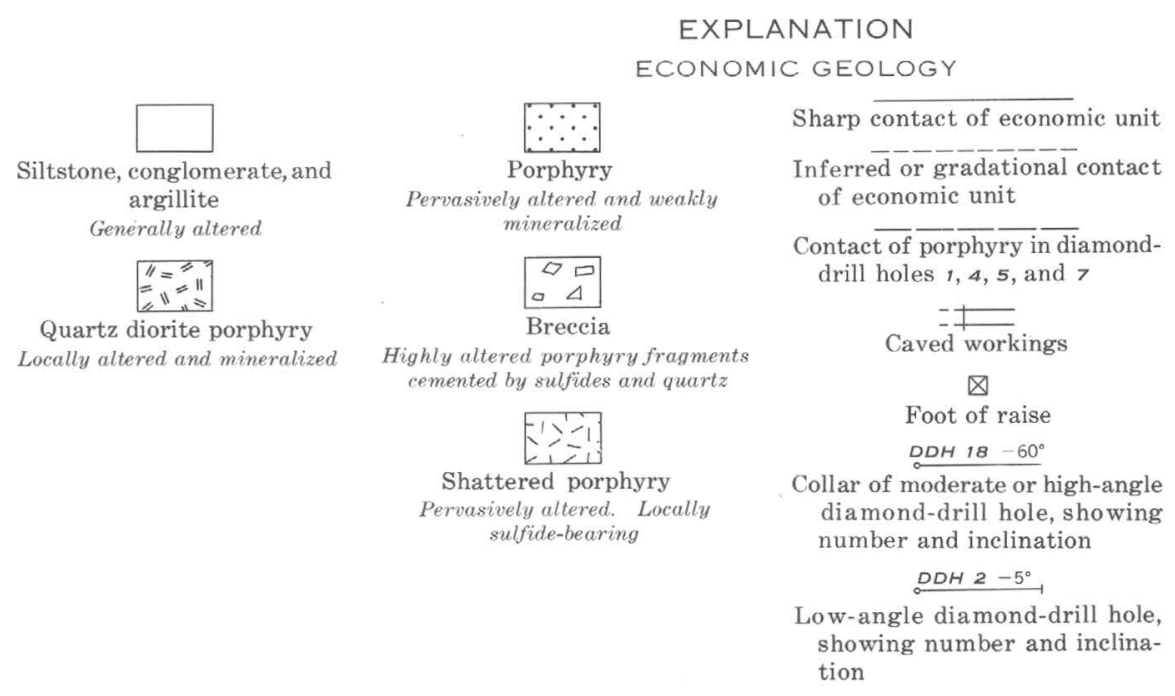

Assay data used in compilation

Sample locality, showing gold in ounce per ton

$0.10 ; 0.50$

Sample locality, showing gold and silver, in order, in ounce per ton

$$
\overbrace{}^{0.01}
$$

Sampled interval, showing average concentration of gold in ounce per ton

$$
\text { 0.08: } 0.30
$$

Sampled interval, showing average concentration of gold and silver, in order, in ounce per ton 

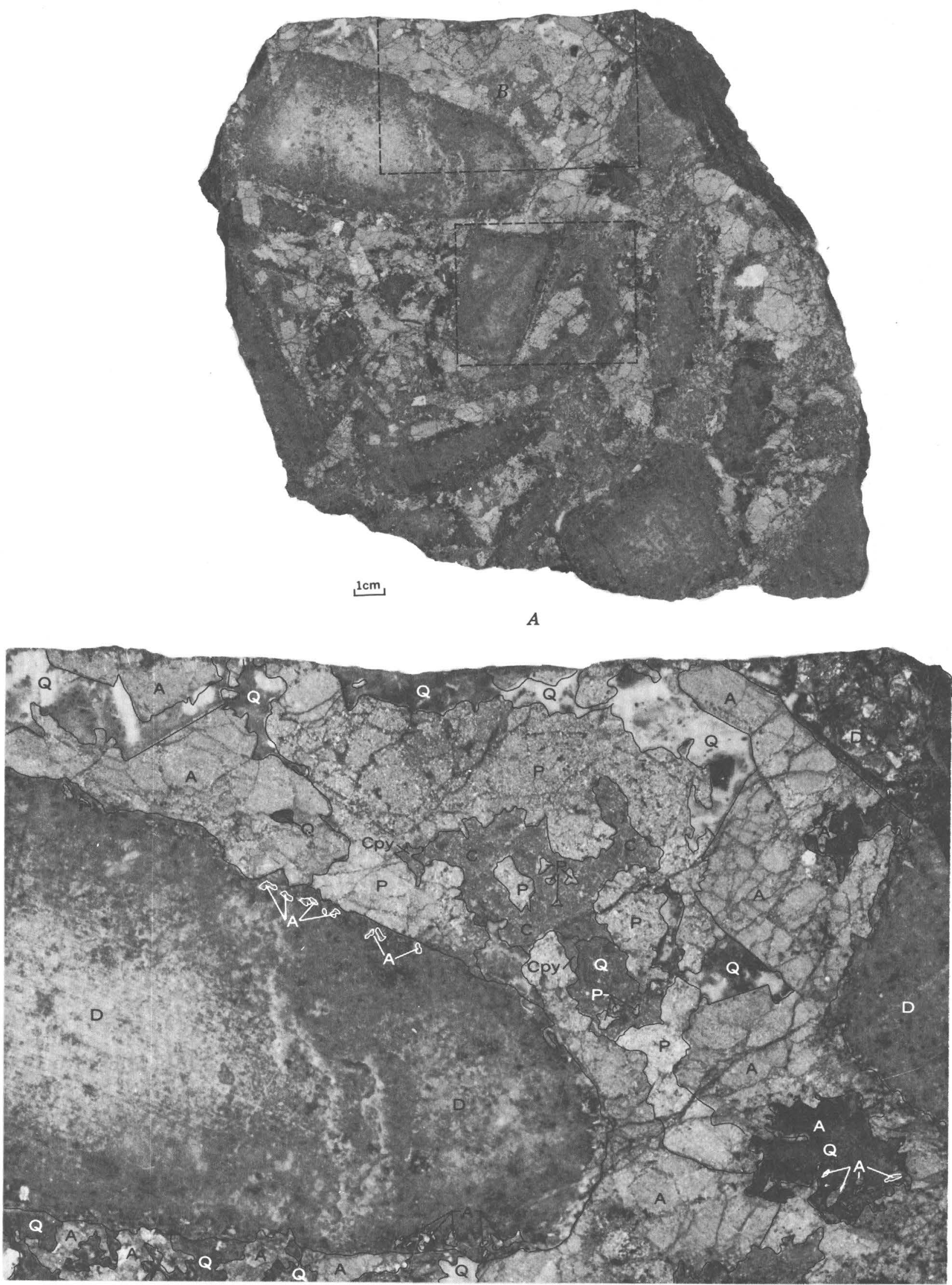


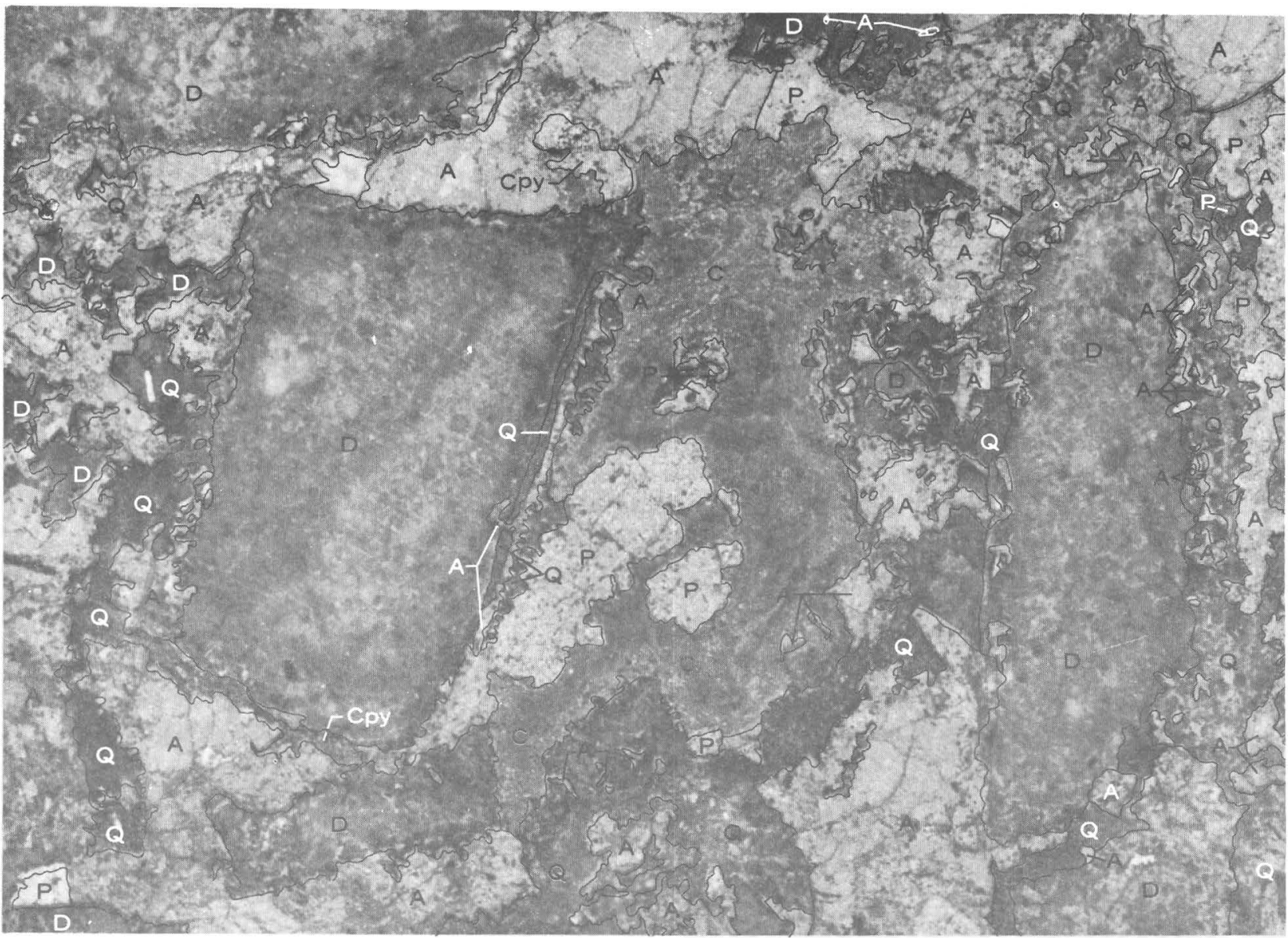

FIGURE 8.-Sulfides in breccia, Golden Zone deposit. A, Specimen of the Golden Zone breccia pipe with angular to subrounded fragments of altered quartz diorite incorporated in a matrix of quartz, pyrite, and arsenopyrite. Area of figures $8 B$ and $8 C$ marked by dashed lines. $B$, Silicified quartz diorite breccia fragments (D) are surrounded by a matrix of arsenopyrite (A), pyrite (P), quartz (Q), and minor chalcopyrite (Cpy). Quartz is emplaced along crystal faces of arsenopyrite. Small euhedral crystals of arsenopyrite replace the breccia fragment near the margins. Arsenopyrite

$0.2 \mathrm{ppm}$ to $14 \mathrm{ppm}$. The samples also consistently contain lead and zinc; antimony is locally present in strongly anomalous amounts, and bismuth, cadmium, and tin were detected in trace amounts in some samples.

Colluvial samples from south of the vein exposures in an old trench also show the presence of mineralized rock. Twelve samples were taken from the trench at 50 -foot intervals. Gold was detected in most samples, and anomalous amounts of antimony, arsenic, copper, lead, and zinc were detected in the same or in other samples. The analyses suggest that weakly mineralized bedrock underlies nearly all of the 500 -foot-long trench, and that there is a gold-bearing zone in the interval from 50-200 feet (from the west end), which is flanked on the east side by mineralized wallrocks characterized by antimony, arsenic, lead, and zinc. is normally coarsely crystalline. Actual size. C, Silicified quartz diorite breccia fragments (D) are surrounded by a matrix of arsenopyrite (A), pyrite (P), quartz (Q), colloform pyrite (C), and minor chalcopyrite (Cpy). Fragments are surrounded by a zone of quartz with minor arsenopyrite. Colloform pyrite forms around crystalline pyrite and fills interstices in arsenopyrite. Small euhedral arsenopyrite crystals replace the quartz diorite fragments near their margins. Actual size.

Other mineralized rock is indicated northwest of the exposed vein system. Here, in a series of ground sluiced trenches, gold was detected, in all but one sample, from the surficial materials collected at the toes of the excavated trenches. These trenches may be on the old Golden Zone Extension claims.

\section{LOOKOUT MOUNTAIN OCCURRENCE}

The Lookout Mountain occurrence is in a locally brecciated and poorly exposed body of quartz porphyry and felsite; this body is emplaced in strongly sheared dark-gray to black argillite and quartzite. Scattered outcrops (pl. 2) suggest that the inirusion is roughly circular and has a diameter of approximately 1,200 feet.

The intrusive rock is light colored and varies from uniformly fine-grained felsite to quartz porphyry with 
TABLE 14.-Analyses of rock samples from Golden Zone mine area

[Analysts: Spectrographic analyses by Arnold Farley, Jr., and F. E. Martinez; gold, by atomic absorption, by W. L. Campbell, A. L. Meier, R. L. Miller, and T. A. Roemer; gold, fire assay, by $0.7,1.0,1.5$, and so on. $\mathrm{N}=$ not detected; $\mathrm{L}=$ detected but below limit of determination; ....... =not looked for; $>=$ greater than; $\langle=$ less than. Results are given in parts per million except for $\mathrm{Fe}$ and Ti, which are given in percent. Sample localities are shown on pl. 2$]$

\begin{tabular}{|c|c|c|c|c|c|c|c|c|c|c|c|c|c|c|c|c|c|c|c|c|c|c|c|c|c|c|c|}
\hline $\begin{array}{l}\text { Sam. } \\
\text { No. }\end{array}$ & $\begin{array}{l}\text { Lab. } \\
\text { No. }\end{array}$ & $\begin{array}{l}\text { Fiel } \\
\text { No }\end{array}$ & & $\mathrm{Ag}$ & As & $\mathrm{Au}$ & $\mathrm{Au}^{1}$ & $\mathrm{Au}^{2}$ & $\mathrm{Bi}$ & $\mathrm{Cd}$ & Co & $\mathrm{Cu}$ & $\mathrm{Hg}^{3}$ & $\mathrm{La}$ & Mo & Mn & $\mathrm{Nb}$ & $\mathrm{Ni}$ & $\mathrm{Pb}$ & $\mathrm{Sb}$ & Se & Sn & $\mathrm{Zn}_{\mathrm{n}}$ & $\mathrm{Zr}$ & $\mathrm{Fe}$ & $\mathrm{Ti}$ & Host rock \\
\hline 1B & ACF 117 & $67 \mathrm{AHx}$ & × 43 & 200 & 7,000 & $\mathrm{~N}$ & 4.2 & 1.9 & 30 & 200 & $\langle 10\rangle$ & $>5,000$ & $\ldots . . .$. & 30 & $\mathrm{~N}$ & 300 & 20 & 5 & 300 & 200 & 15 & 30 & 7,000 & 150 & 10 & 0.3 & Golden Zone. $3 \mathrm{~B}$ and $4 \mathrm{~B}$, respec- \\
\hline $\begin{array}{l}2 \mathrm{~B} \\
3 \mathrm{~B} \\
4 \mathrm{~B} \\
5 \mathrm{~B}\end{array}$ & $\begin{array}{r}116 \\
119 \\
\text { ACE } 627 \\
\text { ACF } 093\end{array}$ & & $\begin{array}{c}42 \\
46 \\
46 \mathrm{D} \\
205\end{array}$ & $\begin{array}{r}100 \\
20 \\
10 \\
\mathrm{~L}\end{array}$ & $\begin{array}{r}>10,000 \\
>10,000 \\
3,000 \\
200\end{array}$ & $\begin{array}{l}\mathrm{L} 1 \\
\mathrm{~N} \\
\mathrm{~N} \\
\mathrm{~N}\end{array}$ & $\begin{array}{c}15 \\
5.0 \\
.4 \\
.09\end{array}$ & $\begin{array}{r}14.8 \\
5.3 \\
\cdots \cdots . . \\
\ldots \ldots .\end{array}$ & $\begin{array}{l}50 \\
70 \\
\mathrm{~N} \\
\mathrm{~L}\end{array}$ & $\begin{array}{l}50 \\
20 \\
30 \\
\mathrm{~N}\end{array}$ & $\begin{array}{r}<10 \\
20 \\
10 \\
7\end{array}$ & $\begin{array}{r}>5,000 \\
1,500 \\
500 \\
50\end{array}$ & $\ldots$ & $\begin{array}{r}30 \\
20 \\
<50 \\
\mathbf{N}\end{array}$ & $\begin{array}{l}\mathrm{N} \\
\mathrm{N} \\
\mathrm{L} \\
\mathrm{N}\end{array}$ & $\begin{array}{l}150 \\
300 \\
700 \\
700\end{array}$ & $\begin{array}{r}20 \\
<20 \\
10 \\
\mathrm{~N}\end{array}$ & $\begin{array}{l}\mathrm{L} \\
15 \\
7 \\
20\end{array}$ & $\begin{array}{l}700 \\
300 \\
500 \\
\mathrm{~L}\end{array}$ & $\begin{array}{l}500 \\
500 \\
N \\
N\end{array}$ & $\begin{array}{r}15 \\
15 \\
5 \\
15\end{array}$ & $\begin{array}{l}50 \\
N \\
N \\
N\end{array}$ & $\begin{array}{l}2,000 \\
1,000 \\
2,000 \\
N\end{array}$ & $\begin{array}{r}150 \\
100 \\
70 \\
30\end{array}$ & $\begin{array}{r}15 \\
15 \\
5 \\
5\end{array}$ & $\begin{array}{l}.3 \\
.3 \\
.3 \\
.2\end{array}$ & 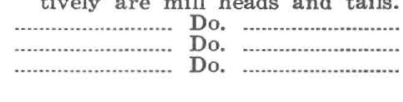 \\
\hline $\begin{array}{r}6 \mathrm{~B} \\
7 \mathrm{~B} \\
8 \mathrm{~B} \\
9 \mathrm{~B} \\
10 \mathrm{~B}\end{array}$ & $\begin{array}{l}118 \\
020 \\
021 \\
174 \\
128\end{array}$ & & $\begin{array}{r}45 \\
\text { III-2 } \\
\text { III-5 } \\
27 \\
28\end{array}$ & $\begin{array}{l}30 \\
30.5 \\
{ }^{30} \\
1.5\end{array}$ & $\begin{array}{r}>10,000 \\
500 \\
>10,000 \\
\quad 300 \\
\quad \mathrm{~N}\end{array}$ & $\begin{array}{l}202 \\
\mathrm{~N} \\
15\end{array}$ & $\begin{array}{l}25 \\
36.04 \\
\stackrel{N}{N}\end{array}$ & $\begin{array}{c}25.0 \\
\cdots \ldots . . \\
\cdots \cdots . \\
\cdots \cdots . . \\
\ldots \ldots .\end{array}$ & $\begin{array}{l}200 \\
\mathrm{~L} \\
15 \\
\mathrm{~N} \\
\mathrm{~N}\end{array}$ & $\begin{array}{l}20 \\
\text { N } \\
\text { N } \\
\text { N }\end{array}$ & $\begin{array}{r}\mathrm{N} \\
20 \\
10 \\
<10 \\
70\end{array}$ & $\begin{array}{r}300 \\
70 \\
2,000 \\
30 \\
150\end{array}$ & $\begin{array}{c}\cdots \cdots . . \\
\cdots \cdots . . \\
\cdots \cdots . . \\
\cdots \cdots . .\end{array}$ & $\begin{array}{l}20 \\
\mathbb{N} \\
N \\
30 \\
N\end{array}$ & $\begin{array}{l}N \\
N \\
N \\
N \\
N\end{array}$ & $\begin{array}{r}20 \\
1,000 \\
500 \\
700 \\
1,500\end{array}$ & $\begin{array}{l}<20 \\
\mathbb{N} \\
N \\
<20 \\
<20\end{array}$ & $\begin{array}{r}\mathrm{N} \\
150 \\
15 \\
30 \\
150\end{array}$ & $\begin{array}{r}5,000 \\
30 \\
500 \\
\mathrm{~N}\end{array}$ & $\begin{array}{l}700 \\
N \\
500 \\
N \\
N\end{array}$ & $\begin{array}{r}N \\
30 \\
5 \\
15 \\
30\end{array}$ & $\begin{array}{l}N \\
N \\
15 \\
N \\
N\end{array}$ & $\begin{array}{l}N \\
N \\
L \\
N \\
N\end{array}$ & $\begin{array}{r}30 \\
50 \\
70 \\
150 \\
70\end{array}$ & $\begin{array}{r}15 \\
5 \\
3 \\
3 \\
3 \\
7\end{array}$ & $\begin{array}{l}.03 \\
.3 \\
.1 \\
.5 \\
.3\end{array}$ & $\begin{array}{l}\text { Little vein. } \\
\text { Little vein (?) projection. } \\
\text { Altered rocks. }\end{array}$ \\
\hline $\begin{array}{l}11 \mathrm{~B} \\
12 \mathrm{~B} \\
12 \mathrm{~B} \\
13 \mathrm{~B} \\
14 \mathrm{~B}\end{array}$ & $\begin{array}{l}107 \\
008 \\
009 \\
010 \\
011\end{array}$ & & $\begin{array}{l}32 \\
126 \mathrm{~A} \\
126 \mathrm{~B} \\
127 \\
128 \mathrm{~A}\end{array}$ & $\begin{array}{r}\mathrm{N} \\
30 \\
10 \\
3 \\
150\end{array}$ & $\begin{array}{r}\mathrm{N} \\
>10,000 \\
1,500 \\
700 \\
>10,000\end{array}$ & $\begin{array}{l}\mathrm{N} \\
\mathrm{L}_{1} \\
\mathrm{~N} \\
\mathrm{~N} \\
10\end{array}$ & $\begin{array}{c}1.04 \\
14^{.4} \\
.1 \\
9.4\end{array}$ & ....... & $\begin{array}{l}\mathrm{N} \\
15 \\
\mathrm{~L} \\
10 \\
30\end{array}$ & $\begin{array}{c}\mathbf{N} \\
\mathbf{N} \\
\mathbf{N} \\
\mathbf{N} \\
300\end{array}$ & $\begin{array}{r}\mathrm{N}_{5} \\
10 \\
7 \\
15\end{array}$ & $\begin{array}{r}30 \\
200 \\
200 \\
200 \\
1,000\end{array}$ & $\begin{array}{l}0.5 \\
\ldots \ldots . . \\
\ldots \ldots . \\
\ldots \ldots . \\
\ldots \ldots . .\end{array}$ & $\begin{array}{l}30 \\
N \\
N \\
N \\
N\end{array}$ & $\begin{array}{l}N \\
N \\
N \\
N \\
N\end{array}$ & $\begin{array}{r}1,500 \\
70 \\
200 \\
150 \\
500\end{array}$ & $\begin{array}{l}20 \\
N \\
N \\
N \\
N\end{array}$ & $\begin{array}{l}30 \\
10 \\
70 \\
70 \\
30\end{array}$ & $\begin{array}{r}30 \\
7,000 \\
150 \\
30 \\
10,000\end{array}$ & $\begin{array}{c}\mathrm{N} \\
1,500 \\
\mathbf{N} \\
\mathbf{N} \\
1,500\end{array}$ & $\begin{array}{l}15 \\
10 \\
15 \\
7 \\
L^{7}\end{array}$ & $\begin{array}{c}\mathrm{N} \\
15 \\
15 \\
10 \\
\mathrm{~N}\end{array}$ & $\begin{array}{c}\mathrm{N} \\
200 \\
300 \\
\mathrm{~N} \\
10,000\end{array}$ & $\begin{array}{r}150 \\
30 \\
20 \\
20 \\
\mathrm{~N}\end{array}$ & $\begin{array}{r}10 \\
7 \\
7 \\
7 \\
10\end{array}$ & $\begin{array}{l}.5 \\
.15 \\
.3 \\
.5 \\
.03\end{array}$ & Altered rock. \\
\hline $\begin{array}{l}14 \mathrm{~B} \\
15 \mathrm{~B} \\
16 \mathrm{~B} \\
17 \mathrm{~B} \\
18 \mathrm{~B}\end{array}$ & $\begin{array}{l}012 \\
108 \\
109 \\
110 \\
111\end{array}$ & & $\begin{array}{c}128 \mathrm{~B} \\
33 \\
34 \\
35 \\
36\end{array}$ & $\begin{array}{r}100 \\
\mathbf{N} \\
\mathbf{N} \\
\mathbf{7} \\
\mathrm{N}\end{array}$ & $\begin{array}{c}>10,000 \\
\mathbf{N} \\
\mathbf{N} \\
\mathbf{N} \\
\mathbf{N}\end{array}$ & $\begin{array}{l}\mathrm{L} \\
\mathrm{N} \\
\mathrm{N} \\
\mathrm{N} \\
\mathrm{N}\end{array}$ & $\begin{array}{l}4.2 \\
\mathrm{~N} \\
.46 \\
.2 \\
.4\end{array}$ & $\ldots . .$. & $\begin{array}{l}\mathrm{L} \\
\mathrm{N} \\
\mathrm{N} \\
\mathrm{N} \\
\mathrm{N}\end{array}$ & $\begin{array}{l}500 \\
\mathbf{N} \\
\mathbf{N} \\
\mathbf{N} \\
\mathbf{N}\end{array}$ & $\begin{array}{r}10 \\
50 \\
<10 \\
20 \\
<10\end{array}$ & $\begin{array}{r}500 \\
500 \\
50 \\
1,000 \\
300\end{array}$ & $\begin{array}{c}.7 \\
.14 \\
2.2 \\
.09\end{array}$ & $\begin{array}{l}\mathrm{N} \\
20 \\
50 \\
\mathrm{~N} \\
30\end{array}$ & $\begin{array}{l}N \\
N \\
N \\
N \\
N\end{array}$ & $\begin{array}{r}500 \\
1,500 \\
1,000 \\
1,500 \\
1,500\end{array}$ & $\begin{array}{c}\mathrm{N} \\
20 \\
<20 \\
<20 \\
<20\end{array}$ & $\begin{array}{r}50 \\
150 \\
15 \\
15 \\
15\end{array}$ & $\begin{array}{c}15,000 \\
N \\
30 \\
N \\
N\end{array}$ & $\begin{array}{l}1,000 \\
\mathbf{N} \\
\mathbf{N} \\
\mathbf{N} \\
\mathbf{N}\end{array}$ & $\begin{array}{l}20 \\
30 \\
20 \\
30 \\
20\end{array}$ & $\begin{array}{l}100 \\
N \\
N \\
N \\
N\end{array}$ & $\begin{array}{c}>10,000 \\
N_{N}^{N} \\
L^{200} \\
L^{200}\end{array}$ & $\begin{array}{r}<10 \\
50 \\
70 \\
50 \\
150\end{array}$ & $\begin{array}{l}10 \\
15 \\
7 \\
20 \\
15\end{array}$ & $\begin{array}{l}.15 \\
.5 \\
.5 \\
.3\end{array}$ & 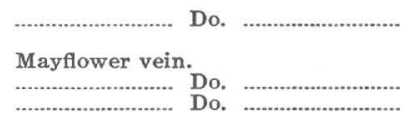 \\
\hline $\begin{array}{l}19 \mathrm{~B} \\
20 \mathrm{~B} \\
21 \mathrm{~B} \\
22 \mathrm{~B} \\
23 \mathrm{~B}\end{array}$ & $\begin{array}{r}112 \\
113 \\
114 \\
115 \\
\text { ACE } 629\end{array}$ & & $\begin{array}{r}37 \\
38 \\
40 \\
41 \\
46 \mathrm{~V} 1\end{array}$ & $\begin{array}{c}1.5 \\
10^{.5} \\
2 \\
15\end{array}$ & $\begin{array}{l}{ }_{N}^{N} \\
>10,000 \\
N^{200}\end{array}$ & $\begin{array}{l}\mathbf{N} \\
\mathbf{N} \\
\mathbf{N} \\
\mathbf{N}\end{array}$ & $\begin{array}{l}.05 \\
.7 \\
.7 \\
1\end{array}$ & $\begin{array}{c}\cdots \cdots . \\
\cdots \cdots . . \\
\cdots \cdots . . \\
\cdots \cdots . . \\
\cdots \cdots . .\end{array}$ & $\begin{array}{l}N \\
N \\
N \\
N \\
N\end{array}$ & $\begin{array}{l}\mathbf{N} \\
\mathbf{N} \\
\mathbf{N} \\
\mathbf{N} \\
\mathbf{N}\end{array}$ & $\begin{array}{r}30 \\
50 \\
100 \\
10 \\
\mathrm{~N}\end{array}$ & $\begin{array}{r}700 \\
1,000 \\
1,000 \\
500 \\
200\end{array}$ & $\begin{array}{c}.08 \\
.08 \\
.65 \\
1.1 \\
\cdots . . .\end{array}$ & $\begin{array}{r}50 \\
N \\
N 0 \\
20 \\
<50\end{array}$ & $\begin{array}{l}N \\
N \\
N \\
N \\
N \\
5\end{array}$ & $\begin{array}{r}1,000 \\
2,000 \\
1,500 \\
1,000 \\
150\end{array}$ & $\begin{array}{r}<20 \\
<20 \\
<20 \\
20 \\
20\end{array}$ & $\begin{array}{l}10 \\
30 \\
20 \\
20 \\
15\end{array}$ & $\begin{array}{l}N \\
N \\
30 \\
N \\
5,000\end{array}$ & $\begin{array}{l}N \\
N \\
N \\
N \\
{ }^{2} 50\end{array}$ & $\begin{array}{l}20 \\
15 \\
20 \\
20 \\
20\end{array}$ & $\begin{array}{l}20 \\
\mathrm{~N} \\
30 \\
\mathrm{~N} \\
\mathrm{~N}\end{array}$ & $\begin{array}{l}\mathrm{N} \\
\mathrm{L} \\
\mathrm{N} \\
\mathrm{N} \\
300\end{array}$ & $\begin{array}{r}70 \\
70 \\
70 \\
100 \\
100\end{array}$ & $\begin{array}{r}15 \\
>20 \\
15 \\
15 \\
10\end{array}$ & $\begin{array}{l}.2 \\
.2 \\
.2 \\
.3 \\
.3\end{array}$ & 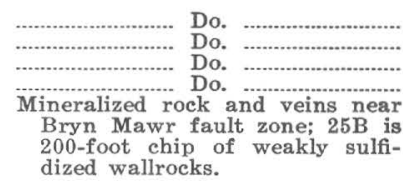 \\
\hline $\begin{array}{l}24 \mathrm{~B} \\
25 \mathrm{~B} \\
26 \mathrm{~B}\end{array}$ & $\begin{array}{r}630 \\
628 \\
\text { ACF } 168\end{array}$ & & $\begin{array}{l}46 \mathrm{~V} 2 \\
\quad 46 \mathrm{~W} \\
21\end{array}$ & $\begin{array}{l}\mathrm{L} \\
3 \\
\mathrm{~N}\end{array}$ & $\begin{array}{l}\mathrm{N} \\
\mathrm{L}\end{array}$ & $\begin{array}{l}\mathbf{N} \\
\mathbf{N}\end{array}$ & $\begin{array}{l}.06 \\
.05\end{array}$ & $\ldots$ & $\begin{array}{l}N \\
N \\
N\end{array}$ & $\begin{array}{l}\mathbf{N} \\
\mathbf{N}\end{array}$ & $\begin{array}{l}\mathrm{N} \\
10 \\
20\end{array}$ & $\begin{array}{r}50 \\
150 \\
100\end{array}$ & $\ldots . .$. & $\begin{array}{r}<50 \\
<50 \\
50\end{array}$ & $\begin{array}{l}\mathrm{L} \\
5 \\
\mathrm{~N}\end{array}$ & $\begin{array}{r}10 \\
50 \\
1,500\end{array}$ & $\begin{array}{l}10 \\
10 \\
\mathbf{N}\end{array}$ & $\begin{array}{r}50 \\
15 \\
150\end{array}$ & $\begin{array}{l}\mathrm{L} \\
100 \\
20\end{array}$ & $\begin{array}{l}{ }^{3} 100 \\
360 \\
\mathrm{~N}\end{array}$ & $\begin{array}{l}\mathrm{N} \\
\mathrm{N} \\
30\end{array}$ & $\begin{array}{l}\mathbf{N} \\
10 \\
\mathbf{N}\end{array}$ & $\begin{array}{l}\mathbf{N} \\
\mathbf{N}\end{array}$ & $\begin{array}{r}70 \\
150 \\
150\end{array}$ & $\begin{array}{l}7 \\
3 \\
7\end{array}$ & $\begin{array}{l}.15 \\
.3 \\
.5\end{array}$ & 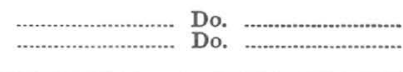 \\
\hline
\end{tabular}



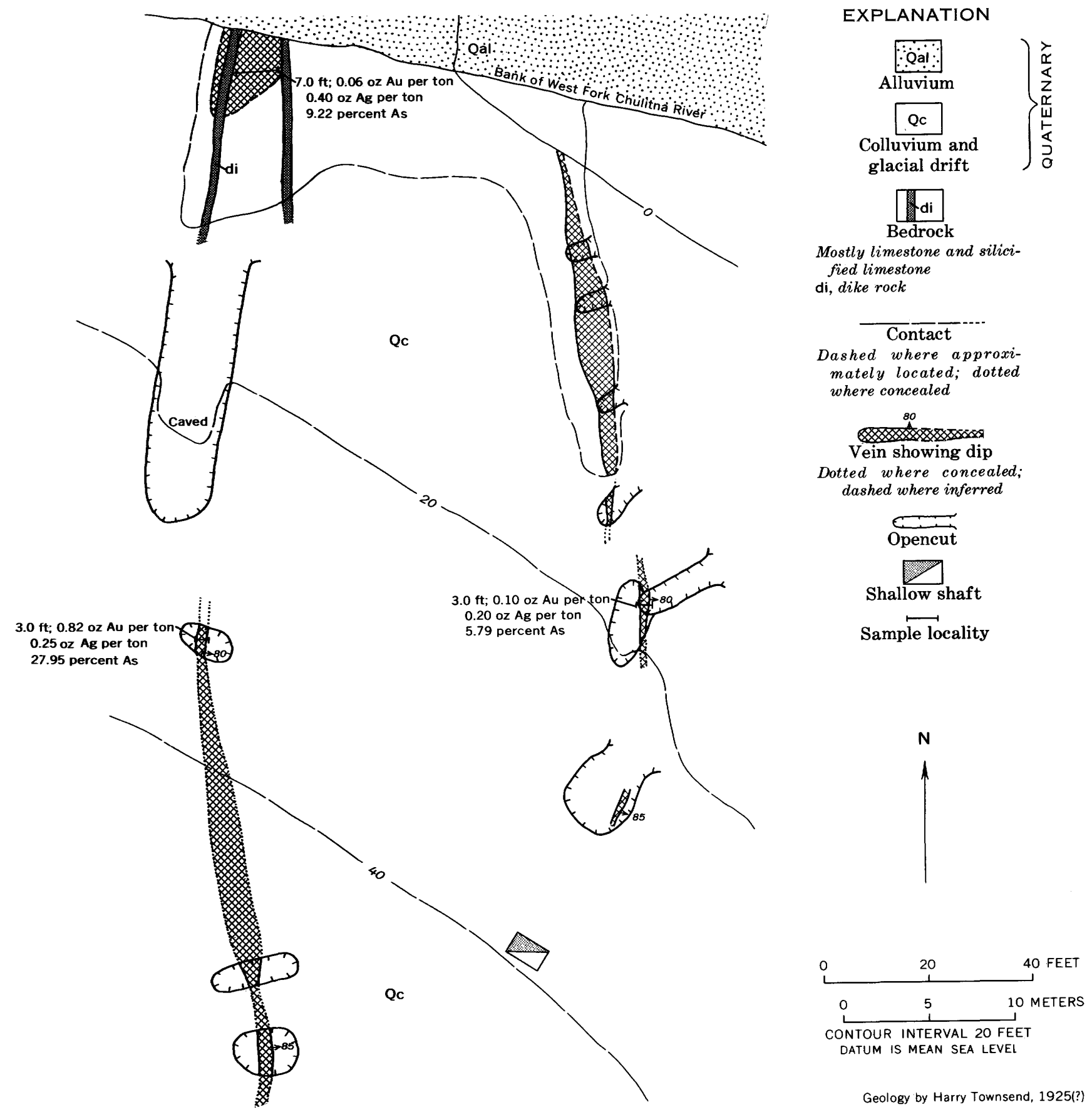

FIGURE 9.-The Riverside prospect.

quartz phenocrysts as much as $\mathbf{2 - 3}$ inches in diameter. Four samples of mineralized intrusive rock which were collected along a small gulch (samples 16A-16D, table 15) contain anomalous amounts of zinc, lead, silver, and arsenic and trace amounts of tin. Shear-zone material in the main intrusive body (samples $16 \mathrm{E}$ and $16 \mathrm{~F}$ ) is also characterized by zinc, lead, silver, and tin, as is a limonite-stained sericitic breccia (sample 16G). Similar breccia containing fragments of both intrusive and country rock is exposed west of the gulch. Silver was detected in the adjacent clastic country rocks (samples $16 \mathrm{H}$ to $16 \mathrm{~J})$.

\section{LONG CREEK PROSPECT}

Shallow trenches and prospect pits south of Long Creek (pl. 2) expose a weakly mineralized area approximately 300 feet wide by 600 feet long. Minor amounts of galena, sphalerite, pyrite, and chalcopyrite occur in massive quartz-arsenopyrite veins and as disseminations in the country rock. 
TABLE 15.-Analyses of rock and stream-sediment samples from the Golden Zone mine area

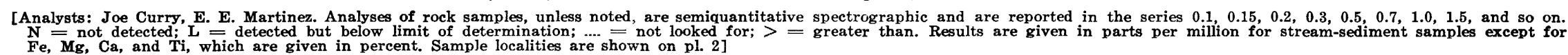

\begin{tabular}{|c|c|c|c|c|c|c|c|c|c|c|c|c|c|c|c|c|}
\hline $\begin{array}{l}\text { Sample } \\
\text { No. }\end{array}$ & $\begin{array}{l}\text { Lab. } \\
\text { No. }\end{array}$ & $\begin{array}{c}\text { Field } \\
\text { No. }\end{array}$ & $\mathrm{Ag}$ & As & $\mathrm{Au}^{1}$ & $\mathrm{Bi}$ & $\mathrm{Cd}$ & $\mathrm{Cu}$ & Mo & $\mathrm{Pb}$ & $\mathrm{Sb}$ & Sn & $\mathrm{Zn}$ & $\mathrm{Fe}$ & $\mathbf{T i}$ & Host rock \\
\hline \multicolumn{17}{|c|}{ Rock samples } \\
\hline $\begin{array}{l}\frac{1}{2} \\
3 \\
4\end{array}$ & $\begin{array}{l}\text { ACF } 090 \\
064 \\
065 \\
089 \\
087\end{array}$ & $\begin{array}{l}67 \mathrm{ACx} \underset{109}{81 \mathrm{~A}} \\
81 \mathrm{~B} \\
98 \\
83\end{array}$ & $\begin{array}{r}10 \\
3 \\
3 \\
1 \\
1\end{array}$ & $\begin{array}{r}>10,000 \\
>1000 \\
>1000 \\
\quad{ }^{700}\end{array}$ & $\begin{array}{c}8.4 \\
13.0 \\
4.8 \\
0.1 \\
.02\end{array}$ & $\begin{array}{l}100 \\
50 \\
50 \\
\mathrm{~L} \\
10\end{array}$ & $\begin{array}{l}\mathrm{N} \\
\mathrm{N} \\
\mathrm{N} \\
\mathrm{N}\end{array}$ & $\begin{array}{r}70 \\
300 \\
500 \\
150\end{array}$ & $\begin{array}{l}\mathrm{N} \\
\mathrm{N} \\
\mathrm{N} \\
\mathrm{N}\end{array}$ & $\begin{array}{l}N^{100} \\
\mathrm{~L}^{150} \\
\mathrm{~L}^{10}\end{array}$ & $\begin{array}{l}\mathrm{N}^{700} \\
\mathrm{~N}^{700}\end{array}$ & $\begin{array}{l}N \\
N \\
N \\
\text { L } \\
\text { L }\end{array}$ & $\begin{array}{l}\mathrm{N} \\
\mathrm{N} \\
\mathrm{N} \\
\mathrm{N}\end{array}$ & $\begin{array}{r}10 \\
3 \\
10 \\
3 \\
7\end{array}$ & $\begin{array}{l}\mathrm{N} \\
\mathrm{N} \\
.005 \\
.2 \\
.3\end{array}$ & $\begin{array}{l}\text { Sheared rhyolite dike. } \\
\text { Banner vein. Arsenopyrite vein. } \\
\text { Banner vein. Contact metamorphosed. } \\
\text { Siliceous siltstone. } \\
\text { Sheared greenstone. }\end{array}$ \\
\hline $\begin{array}{l}5 \\
6 \\
7 \mathrm{~A} \\
\mathrm{~B} \\
\mathrm{C}\end{array}$ & $\begin{array}{l}088 \\
066 \\
017 \\
011 \\
015\end{array}$ & $\begin{aligned} 97 \\
\mathrm{Hx} \\
189 \\
160-3 \\
2 \\
1\end{aligned}$ & $\begin{array}{r}\mathrm{L} \\
\mathrm{N} \\
100 \\
3 \\
15\end{array}$ & $\begin{array}{r}\mathrm{N} \\
1,500 \\
>10,000 \\
1,500 \\
1,000\end{array}$ & $\begin{array}{r}.07 \\
14.06 \\
.2 \\
4.5\end{array}$ & $\begin{array}{l}\mathrm{L} \\
\mathrm{N} \\
15 \\
10 \\
\mathrm{~N}\end{array}$ & $\begin{array}{l}\mathrm{N} \\
\mathrm{N} \\
50 \\
\mathrm{~N}\end{array}$ & $\begin{array}{l}100 \\
50 \\
300 \\
500 \\
50\end{array}$ & $\begin{array}{l}\mathrm{N} \\
\mathrm{N} \\
\mathrm{N} \\
\mathrm{N}\end{array}$ & $\begin{array}{c}\mathrm{L} \\
\mathrm{L} \\
>20,000 \\
50 \\
2,000\end{array}$ & $\begin{array}{l}\stackrel{N}{N} \\
10,000 \\
N_{500}\end{array}$ & $\begin{array}{c}\mathrm{N} \\
\mathrm{N} \\
10 \\
\mathrm{~L} \\
20\end{array}$ & $\begin{array}{l}\mathrm{N} \\
\mathrm{N}_{700} \\
\mathrm{~L}_{300}\end{array}$ & $\begin{array}{r}5 \\
5 \\
10 \\
10 \\
3\end{array}$ & $\begin{array}{l}.3 \\
.2 \\
.2 \\
.2 \\
.3\end{array}$ & $\begin{array}{l}\text { Conglomerate. } \\
\text { Sheared argillite. } \\
\text { Lindfor ars vein. Arsenopyrite vein. } \\
\text { Quartz diorite dike. } \\
\text { Arsenopyrite vein. }\end{array}$ \\
\hline $\begin{array}{l}\underset{E}{F} \\
\underset{8}{G} \\
9\end{array}$ & $\begin{array}{r}004 \\
018 \\
019 \\
019 \\
023 \\
\text { ACE } 612\end{array}$ & 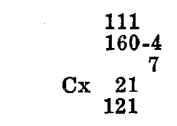 & $\begin{array}{l}150 \\
150 \\
15 \\
10^{.5}\end{array}$ & $\begin{array}{r}>10,000 \\
>10,000 \\
>10,000 \\
\mathrm{~L}_{300}\end{array}$ & $\begin{array}{l}4 \\
3.3 \\
5.4 \\
.02 \\
.3\end{array}$ & $\begin{array}{l}10 \\
\mathrm{~N} \\
20 \\
\mathrm{~L} \\
\mathrm{~N}\end{array}$ & $\begin{array}{l}300 \\
70 \\
\mathbf{N} \\
\mathbf{N}\end{array}$ & $\begin{array}{r}500 \\
300 \\
500 \\
50 \\
50\end{array}$ & $\begin{array}{l}N \\
N \\
N \\
N \\
\text { N }\end{array}$ & $\begin{array}{r}15,000 \\
15,000 \\
500 \\
\mathrm{~L} \\
1,500\end{array}$ & $\begin{array}{c}>10,000 \\
10,000 \\
300 \\
N \\
N\end{array}$ & $\begin{array}{l}\mathrm{N} \\
30 \\
\mathrm{~N} \\
\mathrm{~N} \\
15\end{array}$ & $\begin{array}{l}\begin{array}{l}10,000 \\
2,000 \\
300 \\
300 \\
N\end{array} \\
\mathbb{N}\end{array}$ & $\begin{array}{r}10 \\
10 \\
10 \\
5 \\
5\end{array}$ & $\begin{array}{l}.02 \\
.05 \\
.2 \\
.2\end{array}$ & $\begin{array}{c}\text { Arsenopyrite vein. } \\
\text { Do. } \\
\text { Do. } \\
\text { Siliceous tuff. } \\
\text { Sheared tuff. }\end{array}$ \\
\hline $\begin{array}{l}10 \\
11 \\
12 \mathrm{~A} \\
\text { A } \\
\text { A }\end{array}$ & $\begin{array}{r}\text { ACF } 092 \\
097 \\
098 \\
060\end{array}$ & $\begin{array}{c}\mathrm{Hx} 202 \\
216 \\
218-2 \\
\\
168\end{array}$ & $\begin{array}{r}5 \\
2 \\
50 \\
50 \\
150\end{array}$ & $\begin{array}{l}\mathrm{N} \\
\mathrm{N} \\
\mathrm{N} \\
\mathrm{N} \\
\mathrm{L}\end{array}$ & $\begin{array}{l}.1 \\
.06 \\
1.2 \\
8.0 \\
.2\end{array}$ & $\begin{array}{c}\mathrm{N} \\
\mathrm{N} \\
100 \\
100 \\
50\end{array}$ & $\begin{array}{l}N \\
N \\
N \\
N \\
N\end{array}$ & $\begin{array}{r}3,000 \\
2,000 \\
20,000 \\
110,000 \\
>20,000\end{array}$ & $\begin{array}{l}\mathrm{N} \\
\mathrm{N} \\
\mathrm{N} \\
\mathrm{N} \\
\mathrm{N}\end{array}$ & $\begin{array}{l}\mathrm{L} \\
\mathrm{N} \\
\mathrm{L} \\
\mathrm{L} \\
\mathrm{IN}\end{array}$ & $\begin{array}{l}\mathbf{N} \\
\mathbf{N} \\
\mathbf{N} \\
\mathrm{N}\end{array}$ & $\begin{array}{l}N \\
N \\
30 \\
30 \\
70\end{array}$ & $\begin{array}{l}\mathbb{N} \\
N_{300} \\
3200 \\
1,500\end{array}$ & $\begin{array}{r}3 \\
3 \\
7 \\
7 \\
10 \\
10\end{array}$ & $\begin{array}{l}.2 \\
.05 \\
.1 \\
.2 \\
.1\end{array}$ & 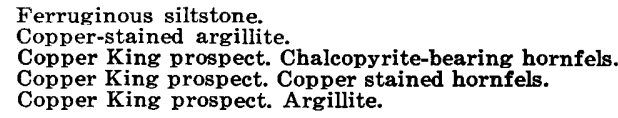 \\
\hline$\underset{\substack{\mathrm{B} \\
\mathrm{C} \\
13}}{1 !}$ & $\begin{array}{r}099 \\
096 \\
061 \\
063 \\
003 \\
\text { ACE } 616\end{array}$ & $\begin{aligned} 218-4 \\
218 \\
\mathrm{Hx} \\
169 \\
108 \\
230 \mathrm{~A}\end{aligned}$ & $\begin{array}{l}30 \\
100 \\
\stackrel{N}{N}\end{array}$ & $\begin{array}{l}\mathrm{N}^{200} \\
\stackrel{N}{N}\end{array}$ & $\begin{array}{c}1.3 \\
6.8 \\
\dddot{N} \\
\stackrel{N}{N}\end{array}$ & $\begin{array}{l}100 \\
100 \\
N \\
\mathbf{N} \\
\mathbf{N}\end{array}$ & $\begin{array}{l}\mathrm{N} \\
\mathrm{N} \\
\mathrm{N} \\
\mathrm{N}\end{array}$ & $\begin{array}{r}5,000 \\
15,000 \\
50 \\
7 \\
100\end{array}$ & $\begin{array}{l}\mathrm{N} \\
\mathrm{N} \\
\mathrm{N} \\
\mathrm{N} \\
\mathrm{N}\end{array}$ & $\begin{array}{l}\mathbf{N}^{10} \\
\mathbf{N}^{10}\end{array}$ & $\begin{array}{l}\mathbf{N} \\
\mathbf{N} \\
\mathbf{N} \\
\mathrm{N}\end{array}$ & $\begin{array}{l}50 \\
30 \\
\mathbb{N} \\
\mathbb{N}\end{array}$ & $\begin{array}{l}\mathrm{L}^{200} \\
\stackrel{\mathrm{N}}{\mathrm{N}}\end{array}$ & $\begin{array}{l}7 \\
7 \\
1.5 \\
2 \\
2\end{array}$ & $\begin{array}{l}.2 \\
.1 \\
.1 \\
.005 \\
.005\end{array}$ & $\begin{array}{l}\text { Copper King prospect. Copper-stained hornfels. } \\
\text { Copper King prospect. Copper-stained hornfels. } \\
\text { Quartz porphyry } \\
\text { Copper-sospained silicious limestone. } \\
\text { Calcite. }\end{array}$ \\
\hline $\begin{aligned} 15 \\
{ }_{16} \\
\text { B } \\
\text { C } \\
\text { D } \\
\text { D }\end{aligned}$ & 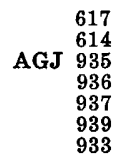 & $\begin{array}{rl} & 230 \mathrm{~B} \\
227 & \\
68 \mathrm{ACs} & 858 \mathrm{D} \\
858 \\
866 \\
868 \mathrm{~B} \\
858 \mathrm{~B}\end{array}$ & $\begin{array}{l}\mathrm{N} \\
\mathrm{N} \\
10 \\
15 \\
3 \\
30 \\
3\end{array}$ & $\begin{array}{l}\mathrm{N} \\
\mathrm{N} \\
\mathrm{N} \\
\mathbf{L} \\
\mathrm{L} \\
\mathrm{L} \\
\mathrm{N}\end{array}$ & $\begin{array}{l}\mathbf{N} \\
\text { N } \\
\text { N } \\
\text { N } \\
0.04 \\
\text { N }\end{array}$ & $\begin{array}{l}\mathbb{N} \\
\mathbf{N} \\
\mathbb{N} \\
\mathbf{N} \\
\mathbb{N} \\
\mathbf{N}\end{array}$ & $\begin{array}{l}\mathbf{N} \\
\mathbf{N} \\
\mathbf{N} \\
\mathbf{N} \\
\mathbf{N} \\
\mathbf{N}\end{array}$ & $\begin{array}{r}10 \\
10 \\
10 \\
10 \\
150 \\
30\end{array}$ & $\begin{array}{l}N \\
\text { L } \\
N \\
N \\
N \\
\text { L } \\
N\end{array}$ & $\begin{array}{l}\mathrm{N} \\
\mathrm{L}_{150} \\
150 \\
150 \\
700 \\
150\end{array}$ & $\begin{array}{l}N \\
N \\
L \\
L \\
N \\
L \\
N\end{array}$ & $\begin{array}{l}N \\
N \\
30 \\
30 \\
15 \\
50 \\
15\end{array}$ & $\begin{array}{l}\mathbb{N}_{500} \\
550 \\
500 \\
\mathrm{~L}_{500}\end{array}$ & $\begin{array}{l}2 \\
7 \\
3 \\
2 \\
3 \\
7 \\
5\end{array}$ & $\begin{array}{l}.002 \\
.005 \\
0.05 \\
.05 \\
.05 \\
.5\end{array}$ & $\begin{array}{l}\text { Jasperoid. } \\
\text { Altered prroxenite (?). } \\
\text { Lookout Mountain. Feesite and quartz porphyry. } \\
\text { Do. } \\
\text { Do. } \\
\text { Do. } \\
\text { Shear-zone material. }\end{array}$ \\
\hline $\begin{array}{l}\mathbf{F} \\
\text { G } \\
\text { H } \\
\text { I } \\
\text { J }\end{array}$ & $\begin{array}{l}934 \\
938 \\
932 \\
6997 \\
940\end{array}$ & $\begin{array}{l}858 \mathrm{C} \\
861 \\
857 \\
862 \\
867\end{array}$ & & $\begin{array}{l}\mathrm{N} \\
\mathrm{N} \\
\mathrm{N} \\
\mathrm{N}\end{array}$ & $\begin{array}{l}\mathbf{N} \\
\mathbb{N} \\
N \\
N\end{array}$ & $\begin{array}{l}\mathrm{N} \\
\mathrm{N} \\
\mathrm{N} \\
\mathrm{N}\end{array}$ & $\begin{array}{l}\mathbf{N} \\
\mathbf{N} \\
\mathbf{N}\end{array}$ & $\begin{array}{r}100 \\
20 \\
20 \\
20 \\
20\end{array}$ & $\begin{array}{l}\mathrm{L} \\
\mathrm{N} \\
\mathrm{L} \\
\mathrm{L} \\
\mathrm{N}\end{array}$ & $\begin{array}{r}70 \\
500 \\
30 \\
30 \\
\mathrm{~L}^{30}\end{array}$ & $\begin{array}{l}N \\
\mathbf{L} \\
\mathrm{N} \\
\mathrm{N} \\
\mathrm{N}\end{array}$ & $\begin{array}{l}10 \\
30 \\
10 \\
\mathrm{~L} \\
\mathrm{~N}\end{array}$ & 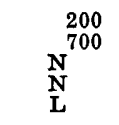 & $\begin{array}{l}7 \\
3 \\
3 \\
3 \\
3 \\
3\end{array}$ & $\begin{array}{l}.5 \\
.75 \\
: .7 \\
: .3\end{array}$ & $\begin{array}{l}\text { Do. } \\
\text { Breccia. } \\
\text { Black argillite and quartzite. } \\
\text { Do. } \\
\text { Do. }\end{array}$ \\
\hline $\begin{array}{r}17 \mathrm{~A} \\
18 \mathrm{~A}\end{array}$ & $\begin{array}{l}\text { ACF } 068 \\
\text { AGJ } \\
\quad 809 \\
\quad 811 \\
827\end{array}$ & $\begin{array}{r}\mathrm{Hx}{ }_{196}^{196} \\
68 \mathrm{ACK} 230 \mathrm{~A} \\
\mathrm{C}\end{array}$ & $\begin{array}{l}1.5 \\
1.5 \\
500 \\
200 \\
700\end{array}$ & $\begin{array}{r}L \\
1,000 \\
>10,000 \\
>10,000 \\
>10,000\end{array}$ & $\begin{array}{l}.06 \\
.30 \\
2.8 \\
3.2 \\
3.2\end{array}$ & $\begin{array}{l}N \\
N \\
300 \\
500 \\
150\end{array}$ & $\begin{array}{c}\mathbb{N} \\
\mathbb{N} \\
500 \\
70 \\
500\end{array}$ & $\begin{array}{r}20 \\
30 \\
3,000 \\
1,000 \\
3,000\end{array}$ & $\begin{array}{l}\text { N } \\
\text { N } \\
7 \\
7 \\
7\end{array}$ & $\begin{array}{l}N_{150} \\
3,000 \\
1,500 \\
3,000\end{array}$ & $\begin{array}{l}\mathbb{N} \\
\mathbb{N} \\
3,000 \\
1,500 \\
2,000\end{array}$ & $\begin{array}{c}\mathbf{N} \\
\mathbf{N} \\
100 \\
\mathbf{N} \\
700\end{array}$ & $\begin{array}{c}\mathrm{N} \\
\mathrm{L} \\
>10,000 \\
>10,000 \\
>10,000\end{array}$ & $\begin{array}{r}2 \\
2 \\
20 \\
20 \\
>20\end{array}$ & $\begin{array}{l}.1 \\
. .1 \\
.01 \\
.03 \\
.015\end{array}$ & $\begin{array}{l}\text { Blind Creek quartz vein. } \\
\text { Long Creek prospect. Vein material. } \\
\text { Do. } \\
\text { Do. }\end{array}$ \\
\hline 18B & $\begin{array}{l}810 \\
817 \\
825\end{array}$ & $\begin{array}{l}\text { B } \\
\text { I } \\
\text { Q }\end{array}$ & ${ }_{\mathrm{L}}^{1.7}$ & $\begin{array}{l}\mathbf{L} \\
N^{300} \\
\end{array}$ & $\begin{array}{l}.2 \\
.06 \\
.04\end{array}$ & $\begin{array}{l}15 \\
\mathrm{~L} \\
\mathrm{~N} \\
\end{array}$ & $\begin{array}{l}\mathbf{N} \\
\mathbf{N} \\
\end{array}$ & $\begin{array}{l}500 \\
300 \\
150\end{array}$ & $\begin{array}{l}\mathrm{L} \\
\mathrm{L} \\
\mathrm{L} \\
\end{array}$ & $\mathrm{L}^{20}$ & $\frac{N}{N}$ & $\begin{array}{l}\mathrm{N} \\
\mathrm{N} \\
\end{array}$ & $\begin{array}{l}\mathrm{L} \\
\mathrm{L} \\
\mathrm{L}\end{array}$ & $\begin{array}{l}7 \\
7 \\
7\end{array}$ & $\begin{array}{l}.3 \\
.5 \\
.5\end{array}$ & $\begin{array}{l}\text { Long Creek prospect. Wallrock. } \\
\text { Do. } \\
\text { Do. }\end{array}$ \\
\hline determ & mination .. & $\ldots \ldots \ldots$ & 0.5 & 200 & 0.02 & 10 & 5 & 5 & 5 & 2 & 10 & 10 & 200 & & 0.001 & \\
\hline
\end{tabular}


TABLE 15.-Analyses of rock and stream-sediment samples from the Golden Zone mine area-Continued

\begin{tabular}{|c|c|c|c|c|c|c|c|c|c|c|c|c|c|c|c|c|c|c|c|c|}
\hline $\begin{array}{l}\text { Sample } \\
\text { No. }\end{array}$ & $\begin{array}{l}\text { Lab. } \\
\text { No. }\end{array}$ & $\begin{array}{l}\text { Field } \\
\text { No. }\end{array}$ & & $\mathbf{A g}$ & As & $\mathbf{A u}$ & Co & $\mathrm{Cr}$ & $\mathrm{Cu}$ & Mo & $\mathbf{M n}$ & $\mathrm{Nb}$ & $\mathbf{N i}$ & $\mathbf{P b}$ & $\mathbf{z}_{\mathbf{n}}$ & $\mathbf{F e}$ & $\mathbf{M g}$ & $\mathrm{Ca}$ & $\mathbf{T i}$ & Remarks \\
\hline $\begin{array}{l}11 \\
12 \\
12 \mathrm{~A}\end{array}$ & $\begin{array}{cc}\text { ACF } & 104 \\
& 103 \\
\text { ACE } & 646 \\
647 \\
648\end{array}$ & $\begin{array}{r}67 \mathrm{AHx} \\
2 \\
2 \\
2\end{array}$ & $\begin{array}{r}31 \\
30 \\
39 \mathrm{a} \\
39 \mathrm{~b} \\
39 \mathrm{p}\end{array}$ & $\begin{array}{l}\mathbf{2} \\
\mathbf{1 . 5} \\
\mathbf{N} \\
\mathbf{N} \\
\mathrm{L}\end{array}$ & $\begin{array}{c}1,500 \\
5,000 \\
N \\
N \\
N\end{array}$ & $\begin{array}{c}N \\
N \\
N \\
0.02 \\
N\end{array}$ & $\begin{array}{l}20 \\
30 \\
15 \\
15 \\
20\end{array}$ & $\begin{array}{r}300 \\
1,500 \\
200 \\
150 \\
2,000\end{array}$ & $\begin{array}{r}100 \\
300 \\
30 \\
50 \\
30\end{array}$ & $\begin{array}{l}\mathbf{N} \\
\mathbf{N} \\
\mathbf{N} \\
\mathbf{N} \\
15\end{array}$ & $\begin{array}{l}, 000 \\
1,000 \\
1,000 \\
1,000 \\
2,000\end{array}$ & $\begin{array}{l}\mathbf{L} \\
\mathrm{L} \\
\mathrm{L} \\
\mathrm{L} \\
\mathrm{L}\end{array}$ & $\begin{array}{r}70 \\
70 \\
100 \\
70 \\
200\end{array}$ & $\begin{array}{l}20 \\
30 \\
10 \\
10 \\
20\end{array}$ & $\begin{array}{l}\mathrm{L} \\
\mathbf{L} \\
\mathrm{L} \\
\mathrm{L} \\
\mathrm{L}\end{array}$ & $\begin{array}{r}15 \\
15 \\
3 \\
5 \\
5\end{array}$ & $\begin{array}{l}0.7 \\
1.5 \\
1.5 \\
1.5 \\
1.5\end{array}$ & $\begin{array}{l}0.7 \\
.7 \\
3 \\
2 \\
3\end{array}$ & $\begin{array}{r}0.2 \\
.5 \\
.3 \\
.3 \\
.3\end{array}$ & $\begin{array}{l}\text { Duplicate of 12A. } \\
\text { Panned concentrate. }\end{array}$ \\
\hline $\begin{array}{l}13 \\
14 \\
15 \\
16 \\
17 \\
17 \mathrm{~A}\end{array}$ & $\begin{array}{rr}\text { ACF } & 069 \\
\text { ACE } & 609 \\
610 \\
611 \\
611 \\
\text { ACF } 032 \\
086\end{array}$ & 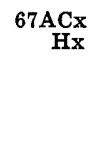 & $\begin{array}{r}64 \\
98 \\
99 \\
100 \\
101 \\
138\end{array}$ & $\begin{array}{l}\stackrel{3}{N} \\
\dot{N}^{7} \\
\stackrel{2}{N}\end{array}$ & $\begin{array}{l}3,000 \\
\mathbf{N} \\
200 \\
\mathbf{N} \\
\mathbf{N} \\
\mathbf{N}\end{array}$ & $\begin{array}{l}.04 \\
\mathrm{~N} \\
\mathrm{~N} \\
\mathrm{~N} \\
.04 \\
\mathrm{~N}\end{array}$ & $\begin{array}{c}20 \\
20 \\
20 \\
15 \\
7 \\
20\end{array}$ & $\begin{array}{r}300 \\
150 \\
100 \\
150 \\
150 \\
70\end{array}$ & $\begin{array}{r}200 \\
100 \\
150 \\
70 \\
30 \\
100\end{array}$ & $\begin{array}{l}\mathbf{N} \\
\mathbf{N} \\
\mathbf{N} \\
\mathbf{N} \\
\mathbf{N} \\
\mathbf{N}\end{array}$ & $\begin{array}{r}700 \\
700 \\
1,000 \\
700 \\
700 \\
1,000\end{array}$ & $\begin{array}{l}L \\
L \\
L \\
L \\
L \\
L\end{array}$ & $\begin{array}{r}100 \\
70 \\
70 \\
50 \\
30 \\
30\end{array}$ & $\begin{array}{r}200 \\
30 \\
70 \\
20 \\
15 \\
200\end{array}$ & $\begin{array}{c}N \\
\mathbf{N} \\
\mathbf{5 0 0} \\
\mathbf{L} \\
\mathbf{N} \\
\mathbf{L}\end{array}$ & $\begin{array}{l}7 \\
5 \\
5 \\
3 \\
1.5 \\
1.5 \\
5\end{array}$ & $\begin{array}{r}1.5 \\
.7 \\
.7 \\
1.7 \\
1.5\end{array}$ & $\begin{array}{r}1.5 \\
.2 \\
.3 \\
.7 \\
.2 \\
.5\end{array}$ & $\begin{array}{l}.5 \\
.3 \\
.3 \\
.5 \\
.3 \\
.5\end{array}$ & \\
\hline $\begin{array}{l}18 \\
19 \\
20 \\
21 \\
22\end{array}$ & $\begin{array}{r}\text { ACE } 607 \\
606 \\
605 \\
604 \\
603\end{array}$ & $67 \mathrm{AHx}$ & $\begin{array}{l}96 \\
95 \\
94 \\
93 \\
92\end{array}$ & $\begin{array}{l}\mathbf{N} \\
\mathbf{N} \\
\mathbf{N} \\
\mathbf{N} \\
\mathbf{N}\end{array}$ & $\begin{array}{l}\mathbf{N} \\
\mathbf{N} \\
\mathbf{N} \\
\mathbf{N} \\
\mathbf{N}\end{array}$ & $\begin{array}{l}\mathbf{N} \\
\mathbf{N} \\
\mathbf{N}\end{array}$ & $\begin{array}{l}30 \\
20 \\
20 \\
20 \\
20\end{array}$ & $\begin{array}{l}150 \\
150 \\
150 \\
150 \\
150\end{array}$ & $\begin{array}{r}100 \\
100 \\
100 \\
70 \\
70\end{array}$ & $\begin{array}{l}\mathbf{N} \\
\mathbf{N} \\
7 \\
N \\
N\end{array}$ & $\begin{array}{r}1,000 \\
1,000 \\
700 \\
700 \\
700\end{array}$ & $\begin{array}{l}L \\
L \\
L \\
L \\
L\end{array}$ & $\begin{array}{r}70 \\
70 \\
100 \\
70 \\
50\end{array}$ & $\begin{array}{l}15 \\
30 \\
15 \\
20 \\
20\end{array}$ & $\begin{array}{c}200 \\
L \\
200 \\
L \\
N\end{array}$ & $\begin{array}{l}\mathbf{5} \\
\mathbf{3} \\
7 \\
\mathbf{5} \\
\mathbf{7}\end{array}$ & $\begin{array}{r}1 \\
.7 \\
.7 \\
.7\end{array}$ & $\begin{array}{l}.5 \\
.15 \\
.7 \\
.2 \\
.3\end{array}$ & $\begin{array}{l}.5 \\
.7 \\
.5 \\
.8 \\
.5\end{array}$ & \\
\hline $\begin{array}{l}23 \\
24 \\
25 \\
26 \\
27\end{array}$ & $\begin{array}{r}602 \\
\text { ACF } 028 \\
026 \\
027 \\
029\end{array}$ & & $\begin{array}{l}91 \\
70 \\
68 \\
69 \\
71\end{array}$ & $\begin{array}{l}\mathbf{N} \\
\mathbf{3} \\
\mathbf{N} \\
\mathbf{N} \\
\mathbf{N}\end{array}$ & $\begin{array}{c}\mathbf{N} \\
5,000 \\
\mathbf{N} \\
\mathbf{N}\end{array}$ & $\begin{array}{l}\mathrm{N} \\
.7 \\
.06 \\
\mathrm{~N} \\
.04\end{array}$ & $\begin{array}{l}20 \\
20 \\
20 \\
20 \\
20\end{array}$ & $\begin{array}{l}150 \\
100 \\
200 \\
300 \\
700\end{array}$ & $\begin{array}{l}100 \\
300 \\
100 \\
150 \\
100\end{array}$ & $\begin{array}{l}\mathbf{N} \\
\mathbf{N} \\
\mathbf{N} \\
\mathbf{N} \\
\mathbf{N}\end{array}$ & $\begin{array}{r}700 \\
700 \\
700 \\
700 \\
1,000\end{array}$ & $\begin{array}{l}L \\
L \\
L \\
L \\
L\end{array}$ & $\begin{array}{r}70 \\
50 \\
100 \\
100 \\
70\end{array}$ & $\begin{array}{l}20 \\
70 \\
10 \\
20 \\
15\end{array}$ & $\begin{array}{c}\mathbf{N} \\
200 \\
\mathbf{N} \\
\mathbf{N} \\
\mathbf{L}\end{array}$ & $\begin{array}{l}7 \\
5 \\
5 \\
5 \\
7\end{array}$ & $\begin{array}{l}1.5 \\
1 \\
3 \\
2 \\
2\end{array}$ & $\begin{array}{l}. .5 \\
1 \\
2 \\
1.5 \\
.7\end{array}$ & $\begin{array}{l}.3 \\
.5 \\
.5 \\
.5 \\
.5\end{array}$ & \\
\hline $\begin{array}{l}28 \\
29 \\
30 \\
31 \\
32\end{array}$ & $\begin{array}{l}031 \\
030 \\
033 \\
082 \\
081\end{array}$ & & $\begin{array}{r}73 \\
72 \\
103 \\
87 \\
86\end{array}$ & $\begin{array}{l}\mathbf{N} \\
\mathbf{N} \\
\mathbf{N} \\
\mathbf{N} \\
\mathbf{N}\end{array}$ & $\begin{array}{l}\mathbf{N} \\
\mathbf{N} \\
\mathbf{N} \\
\mathbf{N} \\
\mathbf{N}\end{array}$ & $\begin{array}{l}\mathrm{N} \\
.02 \\
\mathrm{~N} \\
\mathrm{~N} \\
\mathrm{~N}\end{array}$ & $\begin{array}{l}20 \\
20 \\
20 \\
20 \\
20\end{array}$ & $\begin{array}{r}70 \\
100 \\
70 \\
70 \\
300\end{array}$ & $\begin{array}{r}100 \\
100 \\
70 \\
70 \\
70\end{array}$ & $\begin{array}{l}\mathbf{N} \\
\mathbf{N} \\
\mathbf{N} \\
\mathbf{N} \\
\mathbf{N}\end{array}$ & $\begin{array}{r}1,000 \\
1,000 \\
700 \\
700 \\
700\end{array}$ & $\begin{array}{l}L \\
L \\
L \\
L \\
L\end{array}$ & $\begin{array}{r}30 \\
30 \\
30 \\
30 \\
150\end{array}$ & $\begin{array}{l}20 \\
20 \\
20 \\
30 \\
20\end{array}$ & $\begin{array}{l}\mathbf{N} \\
\mathbf{N} \\
\mathbf{N} \\
\mathbf{N} \\
\mathbf{L}\end{array}$ & $\begin{array}{l}7 \\
7 \\
7 \\
7 \\
5\end{array}$ & $\begin{array}{l}1.5 \\
1.5 \\
1.5 \\
1.5 \\
1.5\end{array}$ & $\begin{array}{l}.5 \\
.3 \\
.7 \\
.7 \\
.3\end{array}$ & $\begin{array}{l}.5 \\
.7 \\
.5 \\
.5 \\
.3\end{array}$ & \\
\hline $\begin{array}{l}33 \\
\mathbf{3 4} \\
\mathbf{3 5} \\
36 \\
\mathbf{3 6}\end{array}$ & $\begin{array}{l}084 \\
085 \\
083 \\
055 \\
035\end{array}$ & & $\begin{array}{r}89 \\
90 \\
88 \\
115 \\
114\end{array}$ & $\begin{array}{l}\mathbf{N} \\
\mathbf{L} \\
\mathbf{N} \\
\mathbf{N} \\
\mathbf{N}\end{array}$ & $\begin{array}{l}\mathbf{N} \\
\mathbf{N} \\
\mathbf{N} \\
\mathbf{N} \\
\mathbf{N}\end{array}$ & $\begin{array}{c}\mathrm{N} \\
\mathrm{N} \\
\mathrm{N} \\
0.02 \\
\mathrm{~N}\end{array}$ & $\begin{array}{l}20 \\
15 \\
15 \\
15 \\
20\end{array}$ & $\begin{array}{l}150 \\
150 \\
300 \\
150 \\
150\end{array}$ & $\begin{array}{l}70 \\
50 \\
50 \\
70 \\
70\end{array}$ & $\begin{array}{l}\mathbf{N} \\
\mathbf{N} \\
\mathbf{N} \\
\mathbf{N} \\
\mathbf{N}\end{array}$ & $\begin{array}{r}1,500 \\
700 \\
700 \\
700 \\
700\end{array}$ & $\begin{array}{l}L \\
L \\
L \\
L \\
L\end{array}$ & $\begin{array}{r}50 \\
50 \\
100 \\
50 \\
50\end{array}$ & $\begin{array}{l}20 \\
70 \\
15 \\
15 \\
15\end{array}$ & $\begin{array}{l}\mathbf{L} \\
\mathbf{L} \\
\mathbf{L} \\
\mathbf{N} \\
\mathbf{N}\end{array}$ & $\begin{array}{l}\mathbf{5} \\
\mathbf{5} \\
\mathbf{5} \\
\mathbf{3} \\
\mathbf{3}\end{array}$ & $\begin{array}{l}2 \\
1 \\
1.5 \\
1 \\
1\end{array}$ & $\begin{array}{l}0.3 \\
.15 \\
.2 \\
.5\end{array}$ & $\begin{array}{r}0.7 \\
.3 \\
.3 \\
.5 \\
.5\end{array}$ & \\
\hline $\begin{array}{l}38 \\
40 \\
41 \\
42\end{array}$ & $\begin{array}{l}034 \\
070 \\
072 \\
071\end{array}$ & & $\begin{array}{r}113 \\
75 \\
77 \\
76\end{array}$ & $\begin{array}{l}\mathbf{N} \\
\mathbf{N} \\
\mathbf{N} \\
\mathbf{N}\end{array}$ & $\begin{array}{l}\mathbf{N} \\
\mathbf{N} \\
\mathbf{N} \\
\mathbf{N}\end{array}$ & $\begin{array}{l}0.02 \\
\mathbf{N} \\
\mathbf{N} \\
\mathbf{N}\end{array}$ & $\begin{array}{l}15 \\
20 \\
15 \\
20\end{array}$ & $\begin{array}{l}100 \\
100 \\
150 \\
300\end{array}$ & $\begin{array}{r}70 \\
70 \\
100 \\
100\end{array}$ & $\begin{array}{l}\mathbf{N} \\
\mathbf{N} \\
\mathbf{N} \\
\mathbf{N}\end{array}$ & $\begin{array}{l}700 \\
700 \\
700 \\
700\end{array}$ & $\begin{array}{l}\mathbf{L} \\
L \\
L \\
L\end{array}$ & $\begin{array}{r}30 \\
50 \\
70 \\
100\end{array}$ & $\begin{array}{l}15 \\
10 \\
15 \\
20\end{array}$ & $\begin{array}{l}\mathbf{N} \\
\mathbf{N} \\
\mathbf{N} \\
\mathbf{N}\end{array}$ & $\begin{array}{l}5 \\
5 \\
5 \\
7\end{array}$ & $\begin{array}{l}1 \\
1.5 \\
1.5 \\
1.5\end{array}$ & $\begin{array}{l}.5 \\
1.5 \\
1.5 \\
.5\end{array}$ & $\begin{array}{l}.5 \\
.5 \\
.5 \\
.7\end{array}$ & \\
\hline $\begin{array}{l}43 \\
44 \\
45 \\
46\end{array}$ & $\begin{array}{l}\mathbf{0 7 3} \\
\mathbf{0 7 4} \\
075 \\
077\end{array}$ & & $\begin{array}{l}78 \\
79 \\
80 \\
82\end{array}$ & $\begin{array}{l}\mathrm{L} \\
\mathbf{7} \\
\mathbf{N} \\
\mathbf{N}\end{array}$ & $\begin{array}{l}\mathrm{L} \\
\mathbf{N} \\
\mathbf{N} \\
\mathbf{N}\end{array}$ & $\begin{array}{l}\mathbf{N} \\
\mathbf{N} \\
\mathbf{N} \\
\mathbf{N}\end{array}$ & $\begin{array}{l}15 \\
30 \\
20 \\
20\end{array}$ & $\begin{array}{r}150 \\
2,000 \\
200 \\
200\end{array}$ & $\begin{array}{r}100 \\
70 \\
70 \\
70\end{array}$ & $\begin{array}{l}\mathbf{N} \\
\mathbf{N} \\
\mathbf{N} \\
\mathbf{N}\end{array}$ & $\begin{array}{r}700 \\
1,000 \\
700 \\
700\end{array}$ & $\begin{array}{l}L \\
L \\
L \\
L\end{array}$ & $\begin{array}{r}70 \\
300 \\
100 \\
150\end{array}$ & $\begin{array}{l}20 \\
70 \\
20 \\
30\end{array}$ & $\begin{array}{l}\mathbf{N} \\
\mathbf{L} \\
\mathbf{N} \\
\mathbf{N}\end{array}$ & $\begin{array}{l}\mathbf{3} \\
7 \\
\mathbf{5} \\
\mathbf{5}\end{array}$ & $\begin{array}{l}1 \\
3 \\
1.5 \\
2\end{array}$ & $\begin{array}{r}.5 \\
.2 \\
1.5 \\
1.5\end{array}$ & $\begin{array}{l}.3 \\
.3 \\
.3 \\
.5\end{array}$ & \\
\hline $\begin{array}{l}47 \\
48 \\
49\end{array}$ & $\begin{array}{l}076 \\
078 \\
079\end{array}$ & & $\begin{array}{l}81 \\
83 \\
84\end{array}$ & $\begin{array}{l}\mathbf{N} \\
\mathbf{N}\end{array}$ & $\begin{array}{l}\mathbf{N} \\
\mathbf{N} \\
\mathbf{N}\end{array}$ & $\begin{array}{l}\mathbf{N} \\
\mathbf{N} \\
\mathbf{N}\end{array}$ & $\begin{array}{l}20 \\
20 \\
20\end{array}$ & $\begin{array}{r}500 \\
1,000 \\
150\end{array}$ & $\begin{array}{r}100 \\
100 \\
70\end{array}$ & $\begin{array}{l}\mathbf{N} \\
\mathbf{N} \\
\mathbf{N}\end{array}$ & $\begin{array}{r}700 \\
700 \\
1,000\end{array}$ & $\begin{array}{l}\mathrm{L} \\
\mathrm{L} \\
\mathrm{L}\end{array}$ & $\begin{array}{l}150 \\
150 \\
150\end{array}$ & $\begin{array}{l}20 \\
15 \\
20\end{array}$ & $\begin{array}{l}\mathbf{N} \\
\mathbf{N} \\
\mathbf{N}\end{array}$ & $\begin{array}{l}7 \\
7 \\
5\end{array}$ & $\begin{array}{l}2 \\
2 \\
.15\end{array}$ & $\begin{array}{r}1.5 \\
2.3\end{array}$ & $\begin{array}{l}.5 \\
.7 \\
.3\end{array}$ & \\
\hline \multicolumn{4}{|c|}{ Limits of determination } & 0.5 & 200 & 0.02 & 5 & 5 & 5 & 5 & 10 & 10 & 2 & 10 & 200 & 0.05 & 0.02 & 0.05 & 0.001 & \\
\hline
\end{tabular}


The country rock consists of dense dark-gray contact metamorphosed conglomerate, breccia, and argillite cut by small dikes and at least one small irregular plug of quartz porphyry. Hornfels near veins contains 1-2 percent disseminated sulfides, primarily pyrite and arsenopyrite, with sparse chalcopyrite. The intrusives are stained with limonite and locally contain abundant arsenopyrite and pyrite.

The analyses given in table 15 represent vein material from shallow trenches $(18 \mathrm{~A})$ and contact metamorphosed hornfels wallrock (18B) that was collected from dumps adjacent to trenches. The analyses show anomalous concentrations of gold, silver, arsenic, molybdenum, and copper with minor amounts of bismuth, lead, antimony, tin, and zinc. The metal suite is typical of the area; but the bismuth, antimony, and tin which are present in larger concentrations and in a higher number of samples here than in most other nearby deposits, is not typical. However, the exposures are so poor that the veins cannot be traced between the trenches, so the extent of well-mineralized material is unknown.

\section{COPPER KING PROSPECT}

The Copper King prospect is in contact metamorphosed hornfels derived from locally calcareous siltstone that is cut by small dikes and plugs of quartz porphyry (pl. 2). The workings consist of several shallow trenches that expose massive chalcopyrite and pyrrhotite. Massive mineralization occurs in lensoid bodies locally 5 feet thick. The quartz porphyry and adjacent hornfels are cut by numerous silica veinlets that contain sparse amounts of molybdenite, chalcopyrite, and pyrite.

Samples from the main trenches at the Copper King (Nos. 12A, Lab. No. ACF097, B, C; table 15) contain about $0.5-2$ percent copper, 1-3 oz silver per ton, gold worth about $\$ 1-\$ 8$ per ton, and detectable amounts of bismuth, zinc, and tin. Mineralized rock from the Copper King is also represented by sample 12A, (Lab. Nos. ACF098 and 060); this prospect sample is a grab sample of sacked ore that was probably taken from the same trench as the other $12 \mathrm{~A}$ samples. Molybdenum, visibly present as molybdenite in veinlets in quartz porphyry near the prospects, was not detected at the prospect but was found in trace amount (15 ppm) in weakly veined porphyry (sample 12D).

\section{READY CASH PROSPECT AND CANYON CREEK OCCURRENCE}

Deposits in the Canyon Creek area are in a unit of interlayered basalt and limestone with minor amounts of contact metamorphosed argillite (pl. 1). The area containing sulfides is more than a mile long and is elongate subparallel to a north-trending fault. A second fault is inferred to follow the valley of Canyon Creek. The deposits are quartz-arsenopyrite-sulfide veins, massive sulfide veins, and disseminated sulfides in basalt, limestone, and hornfels. The minerlized rock was sampled in three parts of the area (pl. 1). Analyses of these samples (table 16) suggest that copper, arsenic, tin, lead, zinc, silver, and minor amounts of gold are characteristic of the mineralized area. With the exception of tin, these metals or their minerals were reported by Capps (1919) and Ross (1933a) at the Ready Cash prospect at the south end of the mineralized area. Tin was detected in all but one sample from the Canyon Creek area. It is perhaps significant that tin-bearing greisen is exposed approximately $31 / 2$ miles northwest of the area.

\section{READY CASH PROSPECT}

The Ready Cash prospect is on the northeast side of Ohio Creek near the mouth of Canyon Creek (pl. 1). The prospect is on a group of nine patented claims (Ross, 1933a, p. 318-320). It has two adits, but only the lower one was located during this study. According to Ross (1933a), the upper adit is a 60-foot long crosscut to a sulfide-bearing vein that strikes N. $20^{\circ} \mathrm{W}$. and dips about $60^{\circ} \mathrm{NE}$.; a sample of an 8-foot width of this vein, which is exposed on the surface, assayed $0.04 \mathrm{oz}$ gold per ton, $25 \mathrm{oz}$ silver per ton, 1.5 percent copper, and 5 percent lead (F. L. Thurmond, unpub. data, 1918). Samples cut underground were of lower grade; both Ross and Thurmond reported a trace of gold and about $2 \mathrm{oz}$ silver per ton. The lower adit had small sulfide-bearing veins, one of which is probably the continuation of a vein sampled in Canyon Creek about 100 feet from the portal (No. 19, table 16, pl. 1). The vein material, though partly oxidized, contains visible arsenopyrite, chalcopyrite, and galena; semiquantitative analyses show the presence of silver, bismuth, cadmium, antimony, tin, and zinc.

\section{CANYON CREEK OCCURRENCE}

Basalt, limestone, or hornfels are mineralized in and near Canyon Creek for at least a mile upstream from the Ready Cash prospect and were sampled at two localities. An arsenopyrite vein at one locality (sample group 20-23, table 16) contained $>0.1$ percent tin; a 50-foot chip sample from the second locality (group 24-26) showed $700 \mathrm{ppm}$ tin and minor amounts of other metals. Basalt is strongly stained with limonite in upper Canyon Creek below the locality of samples 24-26, but it was not sampled because of difficult access.

Sulfide mineral occurrences (sample localities 27A$\mathrm{D}$, table 16, pl. 1) are found in precipitous terrain about $2 \frac{1}{2}$ miles northeast of the Ready Cash prospect. 
TABLE 16.-Analyses of rocks from the Ready Cash prospect, Canyon Creek occurrence, Ohio Creek tin-bearing greisen, Partin Creek occurrence, and other occurrences in the southern part of the Upper Chulitna district

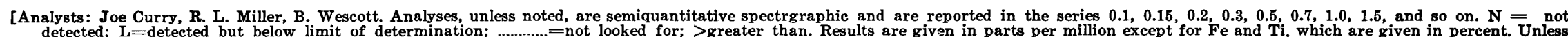
detected; $L=$ detected but below limit of determination; ......... $=$ not
noted, samples are grab samples. Sample localities are shown on pl. 2$]$

\begin{tabular}{|c|c|c|c|c|c|c|c|c|c|c|c|c|c|c|c|c|c|c|}
\hline $\begin{array}{c}\text { Sample } \\
\text { No. }\end{array}$ & $\begin{array}{l}\text { Lab. } \\
\text { No. }\end{array}$ & $\begin{array}{c}\text { Field } \\
\text { No. }\end{array}$ & Ag & As & $\mathbf{A u}^{1}$ & $\mathrm{Be}$ & $\mathbf{B i}$ & $\mathrm{Cd}$ & Co & $\mathrm{Cu}$ & Mo & $\mathrm{Pb}$ & $\mathbf{S b}$ & Sn & $\mathrm{Zn}$ & $\mathrm{Fe}$ & $\mathbf{T i}$ & Host rock \\
\hline \multicolumn{19}{|c|}{ Ready Cash prospect ${ }^{2}$} \\
\hline 19 & AGJ 979 & $\begin{array}{ll}57-9 \\
\end{array}$ & 150 & $>10,000$ & 0.3 & $\mathbf{L}$ & 30 & 300 & 15 & 17,800 & 10 & 1,000 & 100 & 300 & 7,000 & 15 & 0.7 & \multirow{2}{*}{$\begin{array}{l}\text { Chalcopyrite-arsenopyrite vein in Canyon Creek } \\
\text { about } 100 \text { feet from portal of lower adit. 2-ft. chip. } \\
\text { Quartz-arsenopyrite-galena vein. } \\
\text { Copper-stained gossan. } \\
\text { Limonitic hornfess. } \\
\text { Limonitic hornfels and quartz-pyrite vein. } \\
\text { Limonitic basalt unit, about } 30 \text { feet wide. }\end{array}$} \\
\hline $\begin{array}{l}20 \\
21 \\
22 \\
23\end{array}$ & $\begin{array}{l}869 \\
865 \\
866 \\
867 \\
868\end{array}$ & $\begin{array}{l}-4 \\
-1 \\
-1 B \\
-2 \\
-3\end{array}$ & $\begin{array}{r}500 \\
7 \\
0.7 \\
3 \\
3\end{array}$ & $\begin{array}{c}>10,000 \\
\quad N \\
\mathbf{N} \\
700 \\
500\end{array}$ & $\begin{array}{l}.4 \\
.4 \\
.02 \\
.06 \\
.04\end{array}$ & $\begin{array}{l}\mathbf{N} \\
\mathbf{L} \\
\mathbf{L} \\
\mathbf{L} \\
\mathbf{L}\end{array}$ & $\begin{array}{c}\mathrm{L} \\
15 \\
\mathbf{L} \\
\mathbf{L} \\
\mathbf{N}\end{array}$ & $\stackrel{500}{N}$ & $\begin{array}{r}N \\
50 \\
7 \\
\mathbf{L} \\
5\end{array}$ & $\begin{array}{r}3,000 \\
5,000 \\
700 \\
150 \\
300\end{array}$ & $\begin{array}{r}7 \\
15 \\
7 \\
7 \\
7\end{array}$ & 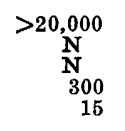 & $\begin{array}{l}700 \\
\mathbf{N} \\
\mathbf{N} \\
\mathbf{N} \\
\mathbf{N}\end{array}$ & $\begin{array}{c}>1,000 \\
\stackrel{L}{L} \\
\mathrm{~L}_{10}\end{array}$ & $\begin{array}{c}10,000 \\
\stackrel{L}{N} \\
\text { L } \\
200\end{array}$ & $\begin{array}{r}15 \\
10 \\
7 \\
5 \\
10\end{array}$ & $\begin{array}{l}.15 \\
.2 \\
.71 \\
.71\end{array}$ & \\
\hline $\begin{array}{l}24 \\
25 \\
26\end{array}$ & $\begin{array}{l}590 \\
591 \\
592 \\
593 \\
\end{array}$ & $\begin{array}{r}\mathrm{M}-812 \\
-814 \\
814 \mathrm{~B} \\
-815 \\
\end{array}$ & $\begin{array}{r}3 \\
10 \\
3 \\
\mathbf{N} \\
\end{array}$ & $\begin{array}{r}\mathrm{L} \\
>10,000 \\
200 \\
\mathrm{~N}\end{array}$ & $\begin{array}{l}.02 \\
.3 \\
.02 \\
.04\end{array}$ & $\begin{array}{l}1 \\
\mathrm{~L} \\
\mathbf{N} \\
\mathbf{N}\end{array}$ & $\begin{array}{l}\mathrm{L} \\
15 \\
\mathbf{N} \\
\mathbf{N}\end{array}$ & & $\begin{array}{l}20 \\
70 \\
20 \\
15 \\
\end{array}$ & $\begin{array}{r}300 \\
1,000 \\
700 \\
100 \\
\end{array}$ & $\begin{array}{r}\mathrm{L} \\
10 \\
5 \\
\mathrm{~N} \\
\end{array}$ & $\begin{array}{r}70 \\
100 \\
\mathrm{~L}^{10} \\
\end{array}$ & $\begin{array}{c}\mathbf{N} \\
500 \\
\mathbf{N} \\
\mathbf{N}\end{array}$ & $\begin{array}{r}700 \\
150 \\
150 \\
\mathbf{N}^{-}\end{array}$ & $\begin{array}{l}300 \\
\mathrm{~L} \\
\mathrm{~L} \\
\mathrm{~N}\end{array}$ & $\begin{array}{r}7 \\
15 \\
10 \\
2 \\
\end{array}$ & $\begin{array}{l}>1 \\
.7 \\
.3 \\
.3\end{array}$ & $\begin{array}{l}\text { Altered basalt, } 50 \text {-foot chip sample. } \\
\text { Arsenopyrite-rich vein } 1 \frac{112-2}{\mathrm{ft}} \text { wide. } \\
\text { Do. } \\
\text { Dark-green to black amygdaloidal basalt. }\end{array}$ \\
\hline \multicolumn{19}{|c|}{ Unnamed occurrence } \\
\hline $\begin{array}{r}27 \mathrm{~A} \\
\mathrm{~B} \\
\mathrm{C} \\
\mathbf{D} \\
28 \mathrm{~A} \\
\end{array}$ & $\begin{array}{l}881 \\
882 \\
884 \\
897 \\
973\end{array}$ & $\begin{array}{r}S 6-43 \\
-45 \\
-46 \\
-46 \mathrm{~B} \\
\mathrm{~S} 7-6 \mathrm{~A}\end{array}$ & $\begin{array}{r}\mathrm{N} \\
2 \\
\mathrm{~N} \\
3 \\
3\end{array}$ & $\begin{array}{l}\mathbf{N} \\
\mathbf{L} \\
\mathbf{N} \\
700 \\
\mathrm{~L}\end{array}$ & $\begin{array}{l}0.1 \\
.9 \\
.1 \\
.8 \\
.04\end{array}$ & $\begin{array}{c}\mathbf{L} \\
1 \\
1 \\
\mathbf{L} \\
5\end{array}$ & $\begin{array}{l}\mathbf{N} \\
\mathbf{N} \\
\mathbf{N} \\
\mathbf{N} \\
\mathbf{L}\end{array}$ & $\begin{array}{l}\mathbf{N} \\
\mathbf{N} \\
\mathbf{N} \\
\mathbf{N} \\
\mathbf{N}\end{array}$ & $\begin{array}{l}20 \\
70 \\
20 \\
15 \\
\mathrm{~N}\end{array}$ & $\begin{array}{r}1150 \\
14,000 \\
1500 \\
300 \\
10\end{array}$ & $\begin{array}{r}5 \\
15 \\
L \\
5 \\
N\end{array}$ & $\begin{array}{l}\mathbf{L} \\
\mathbf{L} \\
\mathbf{L} \\
\mathbf{3 0 0} \\
\mathbf{3 0}\end{array}$ & $\begin{array}{c}\mathbf{N} \\
\mathbf{N} \\
\mathbf{N} \\
\mathbf{3}, 000 \\
\mathbf{N}\end{array}$ & $\begin{array}{l}\mathbf{N} \\
\mathbf{N} \\
\mathbf{N} \\
{ }_{15}\end{array}$ & $\begin{array}{l}200 \\
\mathrm{~L} \\
\mathrm{~N} \\
200 \\
700\end{array}$ & $\begin{array}{c}20 \\
15 \\
7 \\
10 \\
3 \\
\end{array}$ & $\begin{array}{l}0.5 \\
.1 \\
.2 \\
.5 \\
.1\end{array}$ & $\begin{array}{l}\text { Contact zone of basalt and limestone. } \\
1 \text {-to } 11 / 2 \text {-foot wide quartz-sulfide pod or vein. } \\
\text { Sulfide-bearing hornfels. } \\
\text { Colluvial material below AGJ } 884 . \\
\text { Quartz-tourmaline veined granite (float). }\end{array}$ \\
\hline \multicolumn{19}{|c|}{ Ohio Creek tin-bearing greisens } \\
\hline $\begin{array}{l}\mathrm{B} \\
29 \mathrm{~A} \\
30 \\
31\end{array}$ & $\begin{array}{l}974 \\
975 \\
976 \\
977 \\
978\end{array}$ & $\begin{array}{l}-6 \mathrm{~B} \\
-6 \mathrm{D} \\
-6 \mathrm{~F} \\
-6 \mathrm{G} \\
-6 \mathrm{I}\end{array}$ & $\begin{array}{r}5 \\
30 \\
7 \\
70 \\
20\end{array}$ & $\begin{array}{r}\mathrm{N} \\
3,000 \\
\mathrm{~L} \\
300 \\
>10,000\end{array}$ & $\begin{array}{l}0.04 \\
.04 \\
.04 \\
.02 \\
.04\end{array}$ & $\begin{array}{r}5 \\
3 \\
5 \\
15 \\
3\end{array}$ & $\begin{array}{l}10 \\
30 \\
20 \\
\mathbf{N} \\
20\end{array}$ & $\begin{array}{r}150 \\
50 \\
N \\
N \\
N\end{array}$ & $\begin{array}{r}15 \\
5 \\
5 \\
\mathbf{N} \\
\mathbf{N}\end{array}$ & $\begin{array}{r}150 \\
150 \\
1,500 \\
150 \\
1,000\end{array}$ & $\begin{array}{l}\mathrm{L} \\
\mathbf{N} \\
\mathbf{L} \\
\mathbf{N} \\
\mathbf{L}\end{array}$ & $\begin{array}{r}50 \\
200 \\
20 \\
30 \\
300\end{array}$ & $\begin{array}{r}\mathrm{L} \\
\mathrm{L} \\
\mathrm{N} \\
\mathrm{N} \\
150\end{array}$ & $\begin{array}{r}200 \\
>1,000 \\
300 \\
>1,000 \\
>1,000\end{array}$ & $\begin{array}{c}2,000 \\
\mathbf{L} \\
700 \\
\mathrm{~L} \\
\mathrm{~L}\end{array}$ & $\begin{array}{r}10 \\
1.5 \\
7 \\
1 \\
3\end{array}$ & $\begin{array}{l}0.3 \\
.005 \\
.1 \\
L \\
L\end{array}$ & $\begin{array}{l}\text { Mica schist (float). } \\
\text { Muscovite-quartz-arsenopyrite greisen next to AGJ } 976 . \\
\text { Tourmaline-bearing greisen. } \\
\text { Quartz-muscovite greisen. } \\
\text { Quartz-arsenopyrite vein parallel to granite contact. }\end{array}$ \\
\hline \multicolumn{19}{|c|}{ Partin Creek occurrence } \\
\hline $\begin{array}{r}2 \mathbf{A} \\
\mathbf{B} \\
\mathbf{C} \\
\mathbf{D} \\
\mathbf{E}\end{array}$ & $\begin{array}{r}\text { ACL } 503 \\
504 \\
505 \\
506 \\
507\end{array}$ & $\begin{array}{r}68 \text { ACK } 344 \mathrm{~A} \\
\mathrm{~B} \\
\mathrm{C} \\
\mathrm{D} \\
\mathrm{E}\end{array}$ & $\begin{array}{l}0.7 \\
\mathbf{N} \\
\mathbf{N} \\
\mathbf{N} \\
\mathbf{L}\end{array}$ & $\begin{array}{l}1,500 \\
700 \\
N \\
N \\
N\end{array}$ & $\begin{array}{l}0.1 \\
.5 \\
\mathbf{N} \\
.1 \\
.9\end{array}$ & $\begin{array}{l}N \\
L \\
1 \\
N \\
N\end{array}$ & $\begin{array}{l}\mathbf{N} \\
\mathbf{N} \\
\mathbf{N} \\
\mathbf{N} \\
\mathbf{N}\end{array}$ & $\mathbf{N}$ & $\begin{array}{l}20 \\
10 \\
10 \\
30 \\
20\end{array}$ & $\begin{array}{r}200 \\
1,500 \\
20 \\
300 \\
700\end{array}$ & $\begin{array}{c}\mathbf{L} \\
15 \\
\mathbf{L} \\
5 \\
\mathbf{L}\end{array}$ & $\begin{array}{l}\mathbf{L} \\
\mathrm{L}^{20} \\
\mathrm{~L}^{20}\end{array}$ & $\begin{array}{l}\mathbf{N} \\
\mathbf{N} \\
\mathbf{N} \\
\mathbf{N} \\
\mathbf{N}\end{array}$ & $\mathbf{N}$ & $\begin{array}{l}\mathrm{L} \\
\mathrm{L} \\
\mathrm{N} \\
\mathrm{L} \\
\mathrm{N}\end{array}$ & $\begin{array}{c}10 \\
20 \\
3 \\
15 \\
10\end{array}$ & $\begin{array}{l}0.5 \\
.7 \\
.5 \\
>1 \\
>1\end{array}$ & $\begin{array}{l}\text { Grab sample of altered rock. } \\
\text { Do. } \\
\text { Do. } \\
\text { Do. } \\
\text { Do. }\end{array}$ \\
\hline $\begin{array}{r}\mathrm{F} \\
\mathrm{G} \\
33 \\
34 \mathrm{~A} \\
\mathrm{~B}\end{array}$ & $\begin{array}{l}508 \\
509 \\
510 \\
511 \\
512\end{array}$ & $\begin{array}{l}\mathbf{F} \\
\mathbf{G} \\
\mathbf{H} \\
\mathbf{I} \\
\mathbf{J}\end{array}$ & $\begin{array}{r}\mathrm{N} \\
300 \\
1 \\
.5 \\
.5\end{array}$ & $\begin{array}{c}3,000 \\
N \\
>10,000 \\
500 \\
\mathbf{L}\end{array}$ & $\begin{array}{l}.7 \\
63 \\
.2 \\
.02\end{array}$ & $\begin{array}{l}\mathrm{L} \\
\mathbf{N} \\
\mathrm{N} \\
\mathrm{L} \\
\mathrm{L}\end{array}$ & $\begin{array}{r}\mathbf{N} \\
\mathbf{N} \\
100 \\
\mathbf{N} \\
\mathbf{N}\end{array}$ & & $\begin{array}{r}20 \\
15 \\
700 \\
70 \\
100 \\
\end{array}$ & $\begin{array}{r}700 \\
20 \\
7,000 \\
700 \\
700 \\
\end{array}$ & $\begin{array}{r}7 \\
\mathrm{~L} \\
30 \\
7 \\
10 \\
\end{array}$ & $\begin{array}{l}\mathrm{L} \\
\mathbf{N} \\
100 \\
\mathrm{~L} \\
\mathrm{~L}\end{array}$ & $\begin{array}{r}\mathbf{N} \\
\mathbf{N} \\
7,000 \\
\mathbf{N} \\
\mathbf{N}\end{array}$ & & $\begin{array}{l}\mathbf{L} \\
\mathbf{L} \\
300 \\
\mathbf{L} \\
200 \\
\end{array}$ & $\begin{array}{r}15 \\
7 \\
20 \\
15 \\
20 \\
\end{array}$ & $\begin{array}{l}>1 \\
>1 \\
>015 \\
>1\end{array}$ & $\begin{array}{l}\text { Do. } \\
\text { Do. } \\
\text { Arsenopyrite-quartz vein grab sample of altered rock. } \\
\text { Do. } \\
\text { Do. } \\
\end{array}$ \\
\hline \multicolumn{19}{|c|}{ Unnamed occurrence } \\
\hline $\begin{array}{c}35 \\
36 \mathrm{~A} \\
\stackrel{\mathrm{B}}{\mathrm{C}} \\
37\end{array}$ & $\begin{array}{r}\text { AGJ } 801 \\
830 \\
831 \\
832 \\
837\end{array}$ & $\begin{array}{cc}\text { ACK } & 68201 \\
\text { ACK } & 279 \\
& 279 \mathrm{~A} \\
& 282 \\
& 294\end{array}$ & $\begin{array}{l}\mathrm{L} \\
\mathrm{L} \\
0.7 \\
.7 \\
1\end{array}$ & $\begin{array}{l}\mathbf{N} \\
\mathbf{N} \\
\mathbf{L} \\
\mathbf{N} \\
\mathbf{N}\end{array}$ & $\begin{array}{l}0.3 \\
.06 \\
.04 \\
.04 \\
.02\end{array}$ & $\begin{array}{l}\mathbf{N} \\
\mathbf{N} \\
\mathbf{N} \\
\mathbf{N} \\
\mathbf{N}\end{array}$ & $\begin{array}{l}\mathbf{N} \\
\mathbf{N} \\
\mathbf{N} \\
\mathbf{N} \\
\mathbf{N}\end{array}$ & $\begin{array}{l}\mathbf{N} \\
\mathbf{N} \\
\mathbf{N} \\
\mathbf{N} \\
\mathbf{N}\end{array}$ & $\begin{array}{r}150 \\
50 \\
70 \\
\mathbf{N} \\
70\end{array}$ & $\begin{array}{r}3,000 \\
200 \\
70 \\
7,000 \\
10\end{array}$ & $\begin{array}{r}10 \\
5 \\
L \\
7 \\
\mathbf{L}\end{array}$ & $\begin{array}{l}N \\
\mathrm{~L} \\
\mathrm{~L} \\
\mathrm{~L} \\
\mathbf{1 0}\end{array}$ & $\begin{array}{l}\mathbf{N} \\
\mathbf{N} \\
\mathbf{N} \\
\mathbf{N} \\
\mathbf{N}\end{array}$ & $\begin{array}{l}\mathbf{N} \\
\mathbf{N} \\
\mathbf{N} \\
\mathbf{N}\end{array}$ & $\begin{array}{l}200 \\
\mathrm{~L} \\
\mathbf{L} \\
\mathbf{L} \\
\mathbf{N}\end{array}$ & $\begin{array}{r}20 \\
7 \\
7 \\
15 \\
5\end{array}$ & $\begin{array}{l}0.005 \\
.5 \\
.15 \\
.3 \\
.005\end{array}$ & $\begin{array}{l}\text { Sulfidized serpentinite. } \\
\text { Same location. } \\
\text { Same location. Pyrite and chalcopyrite. } \\
\text { Pyritized serpentinite. }\end{array}$ \\
\hline 38 & $\begin{array}{l}876 \\
878 \\
879 \\
880 \\
84968\end{array}$ & $\begin{array}{r}511-\mathrm{H} 6 \mathrm{~A} \\
\mathrm{H6C} \\
\mathrm{H6D} \\
\mathrm{H6DE} \\
68 \mathrm{ACK} 308\end{array}$ & $\begin{array}{c}15^{\mathrm{N}} \\
1 \\
\dot{\mathrm{N}}\end{array}$ & $\begin{array}{l}\mathbf{N} \\
\mathbf{N} \\
\mathbf{L} \\
\mathbf{N} \\
\mathbf{N}\end{array}$ & $\begin{array}{l}\mathrm{N} \\
.1 \\
.04 \\
.02 \\
.2\end{array}$ & $\begin{array}{l}\mathbf{N} \\
\mathbf{N} \\
\mathbf{N} \\
\mathbf{N}\end{array}$ & $\begin{array}{l}\mathbf{N} \\
\mathbf{N} \\
\mathbf{N} \\
\mathbf{N} \\
\mathbf{N}\end{array}$ & $\begin{array}{l}\mathbf{N} \\
\mathbf{N} \\
\mathbf{N} \\
\mathbf{N} \\
\mathbf{N}\end{array}$ & $\begin{array}{r}50 \\
200 \\
150 \\
50 \\
70\end{array}$ & $\begin{array}{r}1750 \\
175,000 \\
120,000 \\
1120 \\
1,500\end{array}$ & $\begin{array}{c}N \\
15 \\
\mathbf{L} \\
\mathbf{L} \\
\mathbf{L}\end{array}$ & $\begin{array}{l}L_{10} \\
L^{15} \\
L^{15}\end{array}$ & $\begin{array}{l}\mathbf{N} \\
\mathbf{N} \\
\mathbf{N} \\
\mathbf{N} \\
\mathbf{N}\end{array}$ & $\begin{array}{l}\mathbf{N} \\
\mathbf{N} \\
\mathbf{N} \\
\mathbf{N} \\
\mathbf{N}\end{array}$ & $\begin{array}{l}200 \\
200 \\
200 \\
L \\
L\end{array}$ & $\begin{array}{r}7 \\
20 \\
20 \\
3 \\
20\end{array}$ & $\begin{array}{l}.2 \\
.05 \\
.2 \\
.2 \\
<1\end{array}$ & $\begin{array}{l}\text { Sulfidized serpentinite. } \\
\text { Same location. }>50 \text { percent chalcopyrite-pyrite. } \\
\text { Same location, > } 50 \text { percent pyrite. } \\
\text { Same location, Vuggy quartz. } \\
\text { Same location. Massive andesite tuff unit. }\end{array}$ \\
\hline Limits & $\begin{array}{l}\text { s of } \\
\text { rmination }\end{array}$ & ......................... & 0.5 & 200 & 0.02 & 1 & 10 & 20 & 5 & 5 & $\mathbf{5}$ & 10 & 100 & 10 & 200 & 0.05 & 0.001 & \\
\hline
\end{tabular}




\section{OHIO CREEK TIN-BEARING GREISEN}

A greisen-type tin occurrence was found $31 / 2$ miles northwest of the Canyon Creek area in upper Ohio Creek. It consists of muscovite- and tourmaline-bearing greisen and quartz-arsenopyrite veins in a tourmalinebearing granite stock. The stock is about 1 mile long and $1 / 2$-mile wide (pl. 1). The greisen is associated with a biotite-rich inclusion at least $\mathbf{1 5 0}$ feet long. Adjacent to the footwall contact of the inclusion is a zone of tourmaline greisen about 10 feet thick that contains $300 \mathrm{ppm}$ tin (sample No. 29B, table 16). The tourmaline greisen grades downward into muscovite greisen at least 3 feet thick that contains more than $1,000 \mathrm{ppm}$ tin (No. 29A, table 16). Scattered exposures in the gulch suggest that the rock on the southeast flank of the inclusion is also greisenized; one grab sample of greisen collected southeast of the gulch contained more than 1,000 ppm tin (sample No. 30). The northeastern contact of the stock dips into the mountain at about $50^{\circ}$ and at least locally the upper 3-10 feet of the granite has pegmatitic quartz-arsenopyrite veins. A grab sample of one of these veins also contained more than 1,000 ppm tin (sample No. 31). Samples of greisen vein material or altered country rocks also contain measurable amounts of silver, gold, copper, lead, zinc, and tungsten (table 16).

Stream sediments from the gulch draining the greisen-bearing area (average of two samples) contain $150 \mathrm{ppm}$ tin, $200 \mathrm{ppm}$ arsenic, $300 \mathrm{ppm}$ copper, $7 \mathrm{ppm}$ beryllium, $5 \mathrm{ppm}$ silver, $700 \mathrm{ppm}$ zinc, and a trace of tungsten.

\section{PARTIN CREEK OCCURRENCE}

In the Partin Creek area (pl. 1), sulfides occur in a zone at least 3,000 feet long and as much as 1,000 feet wide, which is elongate parallel to the regional structural grain. Rocks within the area contain visible pyrite, arsenopyrite, pyrrhotite, and chalcopyrite. The calcareous rocks of the area are strongly limonite stained and locally only a limonite gossan remains. Sulfides in the basaltic units are generally fresh and occur as disseminations, veinlets, and, locally, as fillings of vesicles in amygdaloidal basalt. Random composite samples were taken at regular intervals along a 1,500-foot traverse in sulfide-bearing rock. Analyses of these samples (Nos. 32A-G ( $34 \mathrm{~A}$ and B) and of a grab sample from a quartz-arsenopyrite vein (No. 33), given in table 16, show 20 to $7,000 \mathrm{ppm}$ ( 0.7 percent) copper, and, in most samples, detectable to abundant amounts of silver, gold, arsenic, and antimony.

\section{OTHER OCCURRENCES}

Pyrite or chalcopyrite was found in serpentinite at three locations south of Ohio Creek (Nos. 36, 37, 38, pl. 1; table 16) and at one to the north (No. 35). The mineralized rocks were found by traversing serpentinite-bearing terrane or by spot helicopter landing (locality 38 ); it is very likely that more deposits would be found by more traversing along the serpentinite and associated basalt. Locality No. 39 is southwest of the Partin Creek occurrence and, like locality 38, roughly parallels the strike relative to the main limestonebasalt rock unit of the area.

\section{REFERENCES CITED}

Brooks, A. H., 1911, The Mount McKinley region, Alaska; U.S. Geol. Survey Prof. Paper 70, 234 p.

Capps, S. R., 1919, Mineral resources of the Upper Chulitna region: U.S. Geol. Survey Bull. 692, p. 207-232.

1940, Geology of the Alaska Railroad region: U.S. Geol. Survey Bull. 907, 201 p.

Elliott, R. L., and Reed, B. L., 1968, Results of stream-sediment sampling between Windy Fork and Post River, southern Alaska Range: U.S. Geol. Survey open-file report.

Fischer, R. P., and Fisher, F. S., 1968, Interpreting panconcentrate analyses of stream sediments in geochemical exploration for gold: U.S. Geol. Survey Circ. 592, 9 p.

Grantz, Arthur, 1966, Strike-slip faults of Alaska: U.S. Geol. Survey open-file report.

Hawley, C. C., and Clark, Allen L., 1968, Occurrences of gold and other metals in the Upper Chulitna district, Alaska: U.S. Geol. Survey Circ. 564, 21 p.

1969, Geochemical maps of an area northwest of the Chulitna River, central Alaska Range: U.S. Geol. Survey open-file report.

1973, Geology and mineral deposits of the ChulitnaYentna mineral belt, Alaska: U.S. Geol. Survey Prof. Paper 758-A, $10 \mathrm{p}$.

Hawley, C. C., Clark, Allen L., and Burfer, J. A., 1968, Geology of the Golden Zone mine area, Alaska: U.S. Geol. Survey open-file report.

Hawley, C. C., Clark, Allen L., Herdrick, M. H., and Clark, S. H. B., 1969, Results of geological and geochemical investigations in an area northwest of the Chulitna River, central Alaska Range, 1968: U.S. Geol. Survey Circ. 617, 19 p.

Hemley, J. J., and Jones, W. R., 1964, Chemical aspects of hydrothermal alteration with emphasis on hydrogen metasomatism: Econ. Geology, v. 59, p. 538-569.

Moffitt, F. H., 1915, The Broad Pass region, Alaska: U.S. Geol. Survey Bull. 608,80 p.

Moxham, R. M., Eckhart, R. A., and Cobb, E. H., 1959, Geology and cement raw materials of the Windy Creek area. Alaska: U.S. Geol. Survey Bull. 1039-D, p. 67-100.

Mulligan, J. J., Warfield, R. S., Wells, R. R., 1967, Sampling a gold-copper deposit, Golden Zone mine, south-central Alaska: U.S. Bureau of Mines open-file report.

Nickel, E. H., Rowland, J.F., and McAdam, R. C., 1963, Wodginite-A new tin-manganese tantalate from Wodgina, Australia and Bernic Lake, Manitoba: Canadian Mineralogist, v. 7, pt. 3, p. 390-401.

Nockolds, S. R., 1954, Average chemical compositions of some igenous rocks: Geol. Soc. America Bull., v. 65, p. 1007-103?.

Reed, B. L., and Elliott, R. L., 1968a, Results of stream sediment sampling in parts of the Southern Alaska Range: U.S. Geol. Survey open-file report. 
1968b, Lead, zinc, and silver deposits at Bowser Creek, McGrath A-2 quadrangle, Alaska: U.S. Geol. Survey Circ. $559,17 \mathrm{p}$.

-1968c, Geochemical anomalies and metalliferous deposits between Windy Fork and Post River, southern Alaska Range: U.S. Geol. Survey Circ. 569, 22 p.

Reed, J. C., Jr., 1961, Geology of the Mt. McKinley quadrangle, Alaska: U.S. Geol. Survey Bull. 1108-A, p. A1-A36.

Richter, D. H., and Matson, N. A., Jr., 1968, Distribution of gold and some base metals in the Slana area, eastern Alaska Range, Alaska: U.S. Geol. Survey Circ. 593, 20 p.

Ross, C. P., 1933a, Mineral deposits near the West Fork of the Chulitna River, Alaska: U.S. Geol. Survey Bull. 849-E, p. 289-333.

-1933b, The Valdez Creek mining district, Alaska: U.S. Geol. Survey Bull. 849-H, p. 425-468.

Silberling, N. J., and Tozier, E. T., 1968, Biostratigraphic classification of the Marine Triassic in North America: Geol. Soc America Spec. paper 110, $63 \mathrm{p}$.
Spencer, A. C., 1906, The Juneau gold belt, Alaska: U.S. Geol. Survey Bull. 287, 160 p.

Tuck, Ralph, 1934, The Curry district, Alaska: U.S. Geol. Survey Bull. 857-C, p. 99-140.

Turekian, K. K., and Wedepohl, K. H., 1961, Distribution of the elements in some major units of the earth's crust: Geol. Soc. America Bull., v. 72, p. 175-192.

Wahrhaftig, Clyde, 1944, Coal deposits of the Costello Creek basin, Alaska: U.S. Geol. Survey open-file report. 1958, Quaternary geology of the Nenana River Valley and adjacent parts of the Alaska Range: U.S. Geol. Survey Prof. Paper 293-A, p. 1-68.

Wahrhaftig, Clyde, and Black, R. F., 1958, Engineering geology along part of the Alaska Railroad: U.S. Geol. Survey Prof. Paper 293-B, p. 69-118.

Wolfe, J. A., and Wahrhaftig, Clyde, 1970, The Cantwell Formation of the central Alaska Range, in Changes in stratigraphic nomenclature by the U.S. Geological Survey, 1969: U.S. Geol. Survey Bull. 1294-A, p. A41-A46. 
